\title{
Effects of Bias-Corrected Regional Climate Projections and Their Spatial Resolutions on Crop Model Results under Different Climatic and Soil Conditions in Austria
}

\author{
Sabina Thaler ${ }^{1,2, *}$, Herbert Formayer ${ }^{1}$, Gerhard Kubu ${ }^{1}$, Miroslav Trnka ${ }^{2,3}$ and Josef Eitzinger ${ }^{1}$ \\ 1 Institute of Meteorology and Climatology, University of Natural Resources and Life Sciences (BOKU), \\ Gregor-Mendel-Straße 33, 1180 Vienna, Austria; herbert.formayer@boku.ac.at (H.F.); \\ gerhard.kubu@boku.ac.at (G.K.); josef.eitzinger@boku.ac.at (J.E.) \\ 2 CzechGlobe-Global Change Research Institute CAS, Belidla 986/4a, 60300 Brno, Czech Republic; \\ mirek_trnka@yahoo.com \\ 3 Institute of Agrosystems and Bioclimatology, Mendel University in Brno, Zemědělská 1, \\ 61300 Brno, Czech Republic \\ * Correspondence: sabina.thaler@boku.ac.at; Tel.: +43-1-47654-81420
}

check for updates

Citation: Thaler, S.; Formayer, H.; Kubu, G.; Trnka, M.; Eitzinger, J. Effects of Bias-Corrected Regional Climate Projections and Their Spatial Resolutions on Crop Model Results under Different Climatic and Soil Conditions in Austria. Agriculture 2021, 11, 1029. https://doi.org/ 10.3390 /agriculture11111029

Academic Editor: Jonas Jägermeyr

Received: 10 September 2021

Accepted: 17 October 2021

Published: 20 October 2021

Publisher's Note: MDPI stays neutral with regard to jurisdictional claims in published maps and institutional affiliations.

Copyright: (c) 2021 by the authors. Licensee MDPI, Basel, Switzerland. This article is an open access article distributed under the terms and conditions of the Creative Commons Attribution (CC BY) license (https:/ / creativecommons.org/licenses/by/ $4.0 /)$.

\begin{abstract}
The quality, reliability, and uncertainty of Austrian climate projections (ÖKS15) and their impacts on the results of the crop model DSSAT for three different orographic and climatic agricultural regions in Austria were analyzed. Cultivar-specific grain yields of winter wheat, spring barley, and maize were simulated for different soil classes to address three main objectives. First, the uncertainties of simulated crop yields related to the ÖKS15 projections were analyzed under current climate conditions. The climate projections revealed that the case study regions with higher humidity levels generally had lower yield deviations than the drier regions (yield deviations from $-19 \%$ to $+15 \%$ ). Regarding the simulated crop types, spring barley was found to be less sensitive to the climate projections than rainfed maize, and the response was greater in regions with a low soil water storage capacity. The second objective was to simulate crop yields for the same cultivars using future climate projections. Winter wheat and spring barley tended to show increased yields by the end of the century due to an assumed $\mathrm{CO}_{2}$-fertilization effect in the range of 3-23\%, especially under RCP 8.5. However, rainfed and irrigated maize were associated with up to $17 \%$ yield reductions in all three study regions due to a shortened growth period caused by warming. The third objective addressed the effects of crop model weather input data with different spatial resolutions $(1$ vs. 5,11 , and $21 \mathrm{~km}$ ) on simulated crop yields using the climate projections. Irrigated grain maize and rainfed spring barley had the lowest simulated yield deviations between the spatial scales applied due to their better water supply conditions. The ranges of uncertainty revealed by the different analyses suggest that impact models should be tested with site representative conditions before being applied to develop site-specific adaptation options for Austrian crop production.
\end{abstract}

Keywords: climate change; DSSAT; ÖKS15; aggregated weather data; winter wheat; spring barley; grain maize

\section{Introduction}

In recent decades, impact models for agriculture, such as dynamic (process-based) crop growth models, have become useful tools for assessing the impacts of climate change and associated weather extremes on crop production [1-5]. These models are complex, constructed according to biophysical processes, and assess genotype $\times$ environment $\times$ management interactions, as well as incorporating system feedback measurements [6,7]. These models have been used for estimating the impacts of climate change on crop growth processes and yields at different scales [8-10]. However, during the assessment of these impacts, uncertainties about the underlying physical, biological, and socioeconomic processes arise [11-21]. 
Simulation results of climate change impact studies are strongly affected in terms of quality, spatial representation, and uncertainty by the climate model outputs and their derived weather parameters, which are used as daily crop model inputs. Related uncertainties may result from climate projections of general circulation models (GCMs) and their downscaling procedures, as well as greenhouse gas emission scenarios $[8,19,22,23]$. By using various GCMs, regional climate models (RCMs) and emission scenarios (RCP 4.5 and RCP 8.5), these uncertainties can be reduced or better addressed as ensembles [24-26]. Several applications have also demonstrated the need to correct climate model biases in advance of the regionalization or downscaling of global climate scenarios [27-31].

Much like climate models, crop models themselves contribute significantly to uncertainty in predicting the effects of climate change impacts on crop yields [16,32-34]. It is important to keep in mind that crop models are still a simple representation of the complex soil-crop-atmosphere system and, consequently, there are numerous sources of uncertainty $[33,35]$. Process descriptions for the response to drought stress, temperature stress, and atmospheric $\mathrm{CO}_{2}$ content, as well as scaling methods and uncertainty information, for instance, are often inadequately addressed or parameterized [8,33,35]. A key issue in agricultural studies on climate change, as well as in the development of possible adaptation options at the regional level, is the spatial resolution of soil properties, weather data, and management as input data for crop models. Different scales must be considered according to the application in question [36]. For example, at the local level, weather data with a high spatial resolution are needed to provide different options to allow the tailoring of adaptation decisions and the estimation of their on-farm impacts [37], thus helping to minimize uncertainties in the modelling chain up to the agroeconomic level [38]. For instance, aggregated weather and soil input data lead to less spatial variability and, consequently, fewer simulated stress events-scenarios that are more pronounced in areas with highly heterogenous weather and soil data [39].

In our study, we analyzed the quality, reliability, and uncertainty of Austrian climate scenarios (ÖKS15) [40] and their impacts on the results of a selected crop model when used as model inputs for three different agricultural regions in Austria. If orography is not represented in sufficient detail, strong spatial climate variations and potential biases in climate projections can arise for regions with complex orography, such as the Eastern Alpine region. Thus, the use of gridded weather and climate data forms a good basis for climate impact studies and risk analyses for Austria [41]. We applied the Austrian climate projections ÖKS15 dataset as the model input data (with 1981-2010 as the baseline and climate scenarios given for 2071-2100) for a dynamic crop model to address three objectives:

1. To identify the sensitivity of simulated crop parameters to the uncertainties in the weather input data (1981-2010) by comparing weather station data to ÖKS15 climate model projections;

2. To explain the effects of future climate change on regional simulated crop yields and their sensitivity to uncertainties in climate models and emission scenarios (RCP 4.5 and RCP 8.5) based on the ÖKS15 projections;

3. To analyze the effects of different spatial resolutions ( $1 \mathrm{vs} .5,11$, and $21 \mathrm{~km}$ ) of the ÖKS15 based weather input data on crop model results.

Based on the results (assessment of uncertainty arising from different parameters through the model chain for various spatial scales), recommendations for the application of impact models were derived, considering the different regional conditions (orography, crop, and soil type) with a view to allowing the development of suitable agriculture adaptation options. 


\section{Materials and Methods}

\subsection{Study Regions}

In our study, we investigated three climatically and orographically different agricultural regions that represent the most important climate zones in the Austrian arable farming regions [42]:

1. The first region is located in north-eastern Austria, Weinviertel, and is represented by weather station Poysdorf $\left(48^{\circ} 4^{\prime} \mathrm{N}, 16^{\circ} 4^{\prime} \mathrm{E}, 225 \mathrm{~m}\right.$ a.s.l.), (Figure 1), which is in the Pannonian climate zone. This zone is semi-arid and continental. Summers are hot with prolonged periods of no rainfall; winters are cold with heavy frosts, but snow cover is rare [43]. The annual mean temperature in Poysdorf from 1981 to 2010 was $9.6^{\circ} \mathrm{C}$, and the mean annual precipitation was $563 \mathrm{~mm}$.

2. The second region is in southern Styria, represented by the weather station Bad Gleichenberg $\left(46^{\circ} 5^{\prime} \mathrm{N}, 15^{\circ} 5^{\prime} \mathrm{E}, 317 \mathrm{~m}\right.$ a.s.l.), which is in the Illyrian climate zone (Figure 1). This area is characterized by both Mediterranean and continental climatic conditions with warm summers and mild winters [43]. The mean average temperature from 1981 to 2010 was $10.3^{\circ} \mathrm{C}$, and the annual precipitation was $797 \mathrm{~mm}$.

3. The third region is located in Upper Austria, represented by the weather station Kremsmünster $\left(48^{\circ} 3^{\prime} \mathrm{N}, 14^{\circ} 8^{\prime} \mathrm{E}, 384 \mathrm{~m}\right.$ a.s.l.). This is a humid area with a temperate climate (Figure 1). It is part of the Central European transition climate zone and is influenced by the Atlantic climate [43]. The mean average temperature from 1981 to 2010 was $9.1^{\circ} \mathrm{C}$, and the mean annual precipitation was $1003 \mathrm{~mm}$.

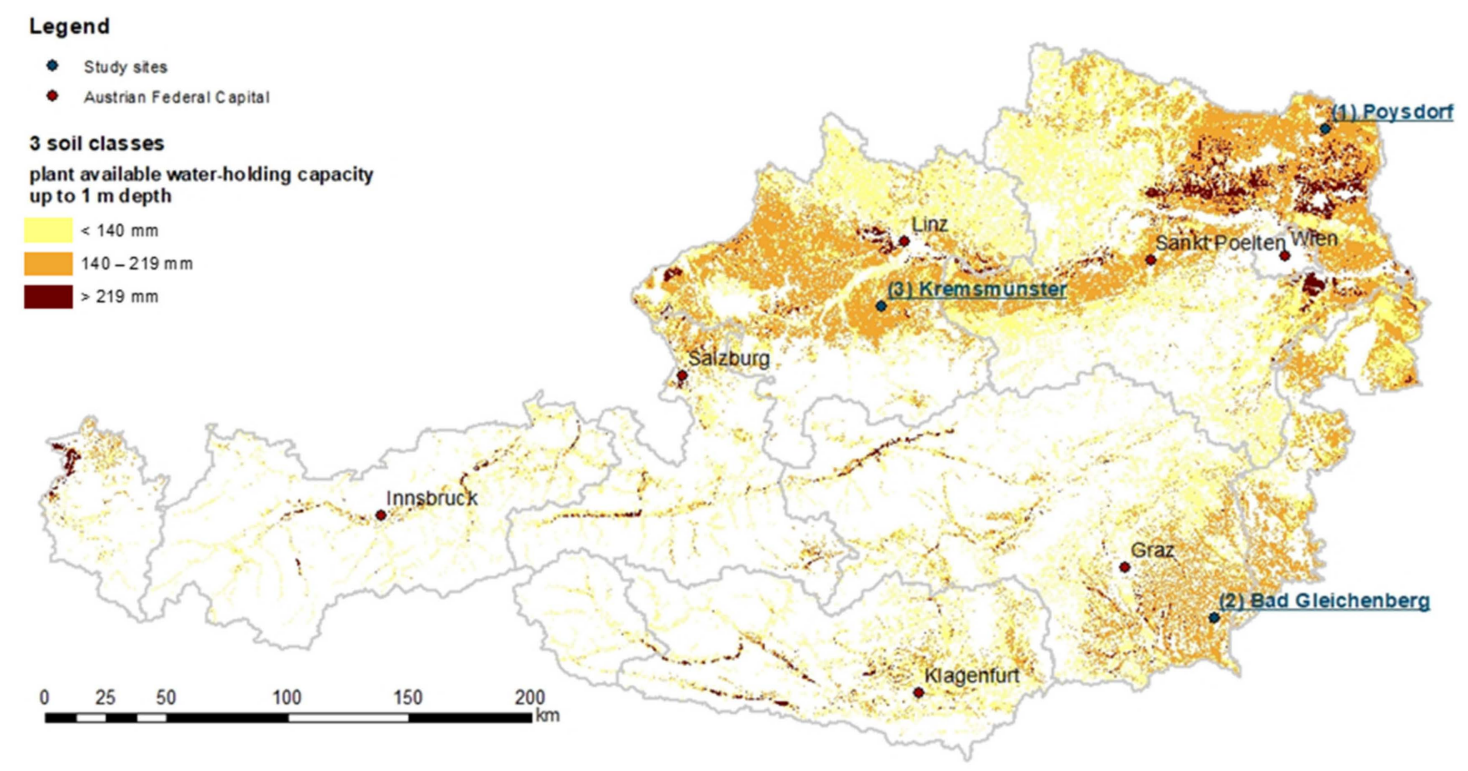

Figure 1. The locations of the weather stations of the three study regions in Austria (blue bold underlined) as well as the distribution of the three main soil classes (soil 1, soil 2, and soil 3) investigated over agricultural land (defined by the plant available water-holding capacity up to $1 \mathrm{~m}$ soil depth in $\mathrm{mm}$ ).

\subsection{The ÖKS15 Austrian Climate Scenarios}

The Austrian climate scenarios ÖKS15 dataset was developed in order to provide a common basis for climate impact studies and risk analyses [40]. It includes climate change data from the 20th and 21st centuries and is represented probabilistically, providing longterm, high-quality, and high-resolution gridded $(1 \mathrm{~km} \times 1 \mathrm{~km})$ observational data on a daily basis. An analysis of past climate changes and bias-corrected regional climate projections for Austria was performed [40]. The historical analysis was based on the GPARD1 (Gridded Precipitation for Austria at Daily $1 \mathrm{~km}$ Resolution) $1 \mathrm{~km} \times 1 \mathrm{~km}$ gridded observation dataset, and projections were made using the Representative Concentrations Pathways (RCPs) [44-48] and the latest available EURO-CORDEX RCM ensemble [49]. Six regional 
models were combined with five GCMs to provide a total of thirteen different climate projections with a horizontal resolution of $12.5 \mathrm{~km}$ for two Representative Concentrations Pathways, RCP 4.5 (moderate development) and RCP 8.5 (business as usual), covering the 1971-2100 period (Table 1). The move to high (1 km grid size) resolutions in ÖKS15 was accomplished with the help of statistical methods. Here, the observational data were of great importance: they defined the grid and served to eliminate systematic deviations (bias) of the modelled variables from measured variables. For the ÖKS15 projections, the RCM data from the EURO-CORDEX initiative ( $12.5 \mathrm{~km}$ grid size) were interpolated onto the GPARD1 grid of observational data (1 km grid size). In a second step, biases in the RCM data were removed using Scaled Distribution Mappings (SDM) [50]. This was carried out grid cell by grid cell, and possible spatial correlations were not considered. Detailed information on the ÖKS15 projections can be found in Chimani et al. [40,41].

Table 1. Combinations of global (GCMs) and regional (RCMs) models from EURO-CORDEX used to generate climate projections for the RCP 4.5 and RCP 8.5 scenarios with a spatial resolution of $12.5 \mathrm{~km}$ (modified from [41]).

\begin{tabular}{lccccccc}
\hline GCM/RCM & ALADIN & CCLM & HIRHAM5 & RACMO & RCA & WRF & sum \\
\hline CNRM-CM5 & 1 & 1 & & & 1 & & 3 \\
EC-EARTH & & 1 & 1 & & 1 & 3 \\
HadGEM2-ES & & 1 & & 1 & 1 & & 3 \\
IPSL-CM5A-MR & & 1 & & & 1 & 1 & 2 \\
MPI-ESM-LR & 1 & 4 & 1 & 1 & 5 & 1 & 13 \\
\hline sum & & & & & & & \\
\hline
\end{tabular}

A comparison of the annual differences in precipitation and temperature changes in Austria between the various ÖKS15 projections for 2071-2100 vs. 1981-2010 are shown in Figure 2. To illustrate the expected range of climatic changes of the ensembles in the three study regions, the differences between the two time periods, 2071-2100 and the baseline, were examined in more detail. In this respect, the mean, median, maximum, and minimum values of the annual maximum (Tmax) and minimum (Tmin) temperatures in Kelvin (K), as well as the change in precipitation (Rain) in percent (\%), were determined across all projections (Table 2). The changes in each of the above weather elements per projection are summarized in Table A1.

In all three study regions, average temperature increases over all projections of $+2 \mathrm{~K}$ in RCP 4.5 and $+3.7 \mathrm{~K}$ in RCP 8.5 were predicted. The strongest increase was projected by HadGEM_CLM. At the same time, higher levels of precipitation were projected, especially in Poysdorf, where an average increase of 10\% in RCP 4.5 and 13\% in in RCP 8.5 was shown, respectively (Table 2). Lower annual precipitation was only found for HadGEM_CLM in Kremsmünster (RCP 4.5, -2\%; RCP 8.5, -3.7\%); MPI_CLM (RCP 4.5, -2.4\%) as well as HadGEM_CLM (RCP 8.5, -6,3\%) in Bad Gleichenberg (Table A1).

\subsection{Impact Model for Crop Production}

The Decision Support System for Agrotechnology Transfer (DSSAT) [51-53] crop growth models were applied as impact models. These models require the input of daily weather data, such as maximum and minimum temperatures, precipitation, global radiation (minimum requirement), layer-specific soil data (soil texture, soil plant available water-holding capacity (SWC), etc.), crop genetic factors, and crop management information (e.g., sowing date, fertilization, and soil tillage). The simulation time steps are made on a daily basis. 


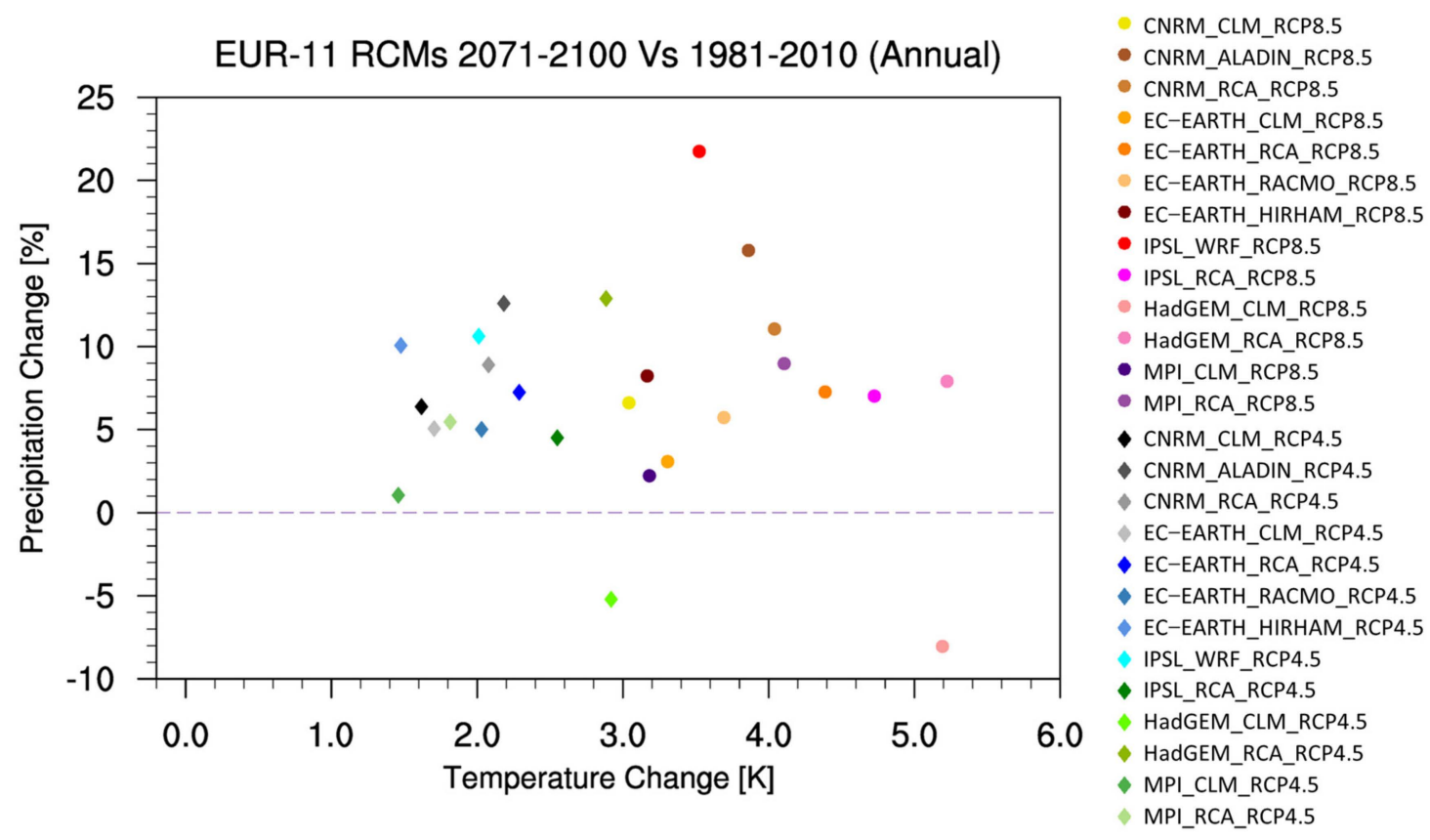

Figure 2. Annual differences in temperature (K) and precipitation (\%) in Austria for the 13 ÖKS15 projections (RCP 4.5 and RCP 8.5): 2071-2100 vs. 1981-2010.

Table 2. Mean, median, maximum (Max), and minimum (Min) annual differences across all projections of maximum (Tmax) and minimum (Tmin) temperatures (K) and precipitation (Rain) in \% (RCP 4.5 and RCP 8.5) in Poysdorf, Bad Gleichenberg, and Kremsmünster: 2071-2100 vs. 1981-2010.

\begin{tabular}{lcccccc}
\hline \multicolumn{1}{c}{ 2071-2100 vs. Baseline } & \multicolumn{3}{c}{ RCP 4.5 } & \multicolumn{3}{c}{ RCP 8.5 } \\
& $\begin{array}{c}\text { Tmax } \\
(\mathrm{K})\end{array}$ & $\begin{array}{c}\text { Tmin } \\
(\mathrm{K})\end{array}$ & $\begin{array}{c}\text { Rain } \\
(\%)\end{array}$ & $\begin{array}{c}\text { Tmax } \\
(\mathrm{K})\end{array}$ & $\begin{array}{c}\text { Tmin } \\
(\mathrm{K})\end{array}$ & $\begin{array}{c}\text { Rain } \\
(\%)\end{array}$ \\
\hline Mean & \multicolumn{3}{c}{ Poysdorf } & & & \\
Median & 1.9 & 2.0 & 10.4 & 3.6 & 3.7 & 13.4 \\
Max & 1.9 & 2 & 10.9 & 3.6 & 3.7 & 11.2 \\
Min & 2.8 & 2.7 & 16.4 & 5 & 4.9 & 33.2 \\
& 1.3 & 1.3 & 4.3 & 2.8 & 3 & 5.6 \\
\hline Mean & Bad Gleichenberg & & & \\
Median & 2.0 & 2.0 & 7.4 & 3.8 & 3.8 & 8.9 \\
Max & 2 & 2 & 6.1 & 3.7 & 3.7 & 6.7 \\
Min & 2.8 & 2.8 & 17.9 & 5.1 & 5 & 36.8 \\
\hline & 1.4 & 1.4 & -2.4 & 3 & 3.1 & -6.3 \\
\hline Mean & \multicolumn{3}{c}{ Kremsmünster } & & & \\
Median & 1.9 & 2.0 & 7.5 & 3.7 & 3.7 & 10.5 \\
Max & 1.8 & 1.9 & 7.8 & 3.4 & 3.6 & 9.5 \\
Min & 3.1 & 2.8 & 16.2 & 5.4 & 5 & 27.5 \\
\hline
\end{tabular}

For meteorological data, we used data from the Austrian Meteorological Service (ZAMG) weather stations and 13 different ÖKS15 projections in RCP 4.5 and RCP 8.5 for the three study regions Poysdorf, Bad Gleichenberg and Kremsmünster (Figure 1). Since the global radiation data for the selected ZAMG stations were not available for the entire time period (1981-2010), they were estimated using a regression function. To estimate the relationships, the daily sunshine duration $(\mathrm{h})$ was related to the level of solar radiation $\left(\mathrm{MJ} / \mathrm{m}^{2} / \mathrm{d}\right)$. To compensate for seasonal variability, regression equations were calculated for each month individually over the 30-year period. 
Three different soil classes, defined by SWC of the 0-1 m soil layer, were used in the study, covering the full range of existing agricultural soils present in Austria (Figure 1):

- Soil class 1: SWC $<140 \mathrm{~mm}$ in the effective root zone, low-value arable areas;

- Soil class 2: SWC 140-220 mm, medium to high-quality arable areas;

- Soil class 3: SWC $>220 \mathrm{~mm}$, high-quality arable areas.

DSSAT models were calibrated and validated for "Capo" winter wheat [54], "Magda" spring barley [55], and "Parsival" grain maize [56] cultivars in the Marchfeld region (which is part of the "Weinviertel" study region) and were thus considered suitable for the simulation of crops in other arable regions in Austria. Fertilization was fixed (winter wheat $2 \times 40 \mathrm{~kg} \mathrm{~N} / \mathrm{ha}, 1 \times 25 \mathrm{~kg} \mathrm{P} / \mathrm{ha}, 1 \times 45 \mathrm{~kg} \mathrm{~K} / \mathrm{ha}$; spring barley: $2 \times 40 \mathrm{~kg} \mathrm{~N} / \mathrm{ha}$, $1 \times 25 \mathrm{~kg} \mathrm{P} / \mathrm{ha}, 1 \times 170 \mathrm{~kg} \mathrm{~K} / \mathrm{ha}$; grain maize: $1 \times 80 \mathrm{~kg} \mathrm{~N} / \mathrm{ha}$ and $1 \times 55 \mathrm{~kg} \mathrm{~N} / \mathrm{ha}$, $1 \times 39 \mathrm{~kg} \mathrm{P} / \mathrm{ha}, 1 \times 166 \mathrm{~kg} \mathrm{~K} / \mathrm{ha}$ ), and the sowing date was selected using the software option "sown under optimum sowing conditions (time window with soil temperature and soil moisture range)". Whereas the cereals, winter wheat, and spring barley were simulated in rainfed mode, grain maize was modelled under both optimum (irrigated) and rainfed conditions. To assess the effects of climate change, including the impact of higher ambient $\mathrm{CO}_{2}$ concentrations on crop yields, the $\mathrm{CO}_{2}$ concentration was assumed to be $380 \mathrm{ppm}$ for the baseline period (1981-2010) and $520 \mathrm{ppm}$ (RCP 4.5) or $750 \mathrm{ppm}$ (RCP 8.5) for the 2071-2100 period to demonstrate different emission scenarios [44]. For the crop models applied in our study, only the weather input data and $\mathrm{CO}_{2}$ concentrations were changed; the other input data were fixed for all simulations under current and future time periods.

\subsection{Methods Used to Analyse the Quality, Reliability, and Uncertainty of the Observational Gridded Data and the ÖKS15 Climate Projections}

The DSSAT models for wheat (CERES-Wheat), barley (CERES-Barley), and maize (CERES-Maize) [51-53] were applied to simulate crop growth and yield for Poysdorf, Bad Gleichenberg, and Kremsmünster under different climate and soil conditions. An analysis of the results was carried out as summarized below:

1. Winter wheat, spring barley, and grain maize yields were simulated at the selected locations for the various soil types and management practices (irrigated, rainfed) using different weather input datasets for baseline (1981-2010). The 30-year yield averages were compared between ZAMG weather station inputs (references) and ÖKS 15 inputs (RCP 4.5 and RCP 8.5) to investigate the effect and sensitivity of the crop model results on individual projections. In the baseline, the differences between RCP 4.5 and RCP 8.5 should be very small; in fact, they were identical between 1981 and 2005, and only after that the scenarios differed slightly. This was just because of noise, as the radiative forcing was effectively still the same [57]. To better understand the simulated yield variations, Pearson's correlation coefficients between evapotranspiration (ET), transpiration (T), evaporation (E), and relative yield deviations were estimated.

2. To explain the sensitivity and uncertainties associated with climate models and emission scenarios based on the ÖKS15 projections, the different $\mathrm{CO}_{2}$ concentrations present in RCP 4.5 and RCP 8.5 were taken as model inputs. Here, differences in the 30-year mean yield were considered (a) between the baseline and 2071-2100 and (b) between RCP 8.5 and RCP 4.5 for 2071-2100. Photosynthetic activity and water use efficiency may improve with increasing atmospheric $\mathrm{CO}_{2}$ levels due to interplay with stomatal conductance; however, large variations in these responses between different plants and environments, which are not considered in the crop models, are possible [58].

3. Selected ÖKS15 projections with a $1 \mathrm{~km}$ grid size were artificially averaged to form coarser resolutions with grid sizes of 5,11 , and $21 \mathrm{~km}$ in order to evaluate the spatial resolution sensitivity in our case study regions. The following projections were examined in more detail as they contained a wide range of different possible future impacts (Figure 2): 
- $\quad$ RCP 4.5: EC-EARTH_RCA, IPSL_RCA and HadGEM_CLM;

- RCP 8.5: EC-EARTH_CLM, EC-EARTH_RACMO, IPSL_WRF, HadGEM_CLM and HadGEM_RCA.

The relative yield differences of the aggregated input data compared to the $1 \mathrm{~km}$ data were evaluated for the two periods, the baseline and 2071-2100, for all three soil classes.

To analyze the levels of uncertainty for these three objectives, we calculated the mean, median, maximum, and minimum values, as well as the $10 \%$ and $90 \%$ percentiles across all ÖKS15 yield deviations to represent the range of expected errors.

\section{Results}

3.1. Uncertainties in the ÖKS15 Projections as Model Input Data for the 1981-2010 Time Period 3.1.1. Uncertainties in Poysdorf, Baseline

The yield deviations in the crop model results for various ÖKS15 projections (in \%) under RCP 4.5 (a) and RCP 8.5 (b) compared with reference simulations using measured weather station data from Poysdorf are shown in Figure 3. Even if the weather data have been bias-corrected on monthly basis, daily deviations, especially during critical growth phases, can strongly influence the predicted yields, which can be seen by the variation in yield predictions across the 13 climate models.

For RCP 4.5 and RCP 8.5, in most cases irrigated maize showed a higher yield than that predicted by simulations with measured weather input data. With EC-EARTH_HIRHAM, for example, a yield increase of up to $8 \%$ was simulated for Poysdorf (Figure 3). The crop with the greatest yield fluctuations in both RCPs was rainfed maize. In particular, the two HadGEM projections showed lower yields by up to $16 \%$ (RCP 8.5), with all three types of soil similarly affected. Both scenarios predicted significantly less precipitation between May and August than that measured at the weather station (not shown); at the same time, Poysdorf was found to be the driest location. This lower level of precipitation was especially observed at HadGEM_CLM. Chimani et al. [38] pointed out a weakness in the performance of this projection for summer precipitation, where errors were found to be greater than $+/-20 \%$. The lower level of precipitation also affected spring barley. Deviations of up to $10 \%$ for RCP 4.5 and 9\% for RCP 8.5 were simulated with HadGEM_RCA. In general, a depression in the spring barley yield was simulated in most projections. Winter wheat reacted similarly, with significantly lower yields of up to $-10 \%$ in the ÖKS15 projections (RCP 4.5, soil 3: HadGEM_RCA).

Pearson's correlation coefficients of evapotranspiration (ET), transpiration (T), and evapotranspiration (E) compared with the relative yield deviations (baseline) for the three soil classes are summarized in Table 3. For irrigated maize, a positive correlation for $\mathrm{T}$ was found for both emission scenarios, reaching values of up to $70 \%$. No significant values were calculated for ET and E. The correlations of ET, T, and E with the variation in yield of rainfed maize was much stronger, illustrating the importance of the representation of the precipitation distribution in summer in the climate scenarios. In this case, $\mathrm{T}$ correlation values of up to $0.91\left(\mathrm{r}^{2} \geq 0.89\right.$, not shown) were achieved. For the other two variables, highly positive linear trends could be seen. For spring barley, strong correlations among ET, T, and yield variability were observed, except for the T values of soil types 2 and 3 in RCP 4.5. The degree of correlation for winter wheat reached significant values for ET (0.71), $\mathrm{T}$ (0.92), and $\mathrm{E}$ (0.51) (RCP 4.5). Thus, yield deviations can be explained with the help of lower or higher transpiration values. 
a)

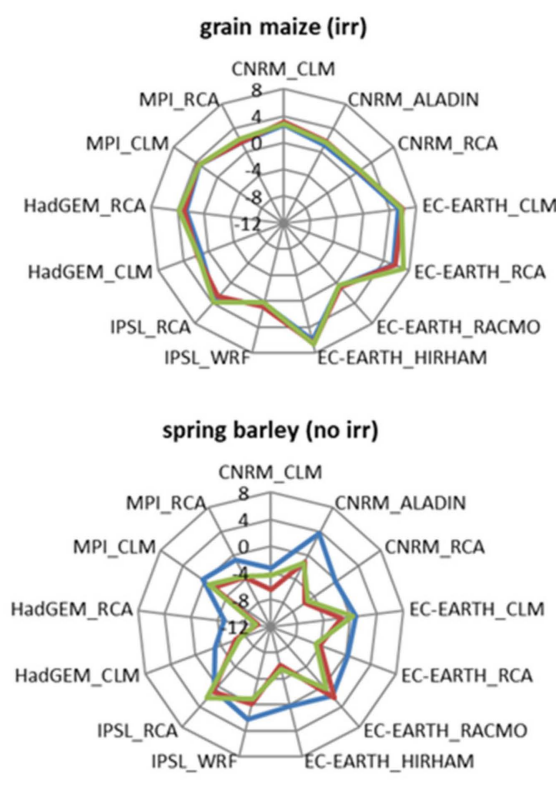

Poysdorf-RCP 4.5

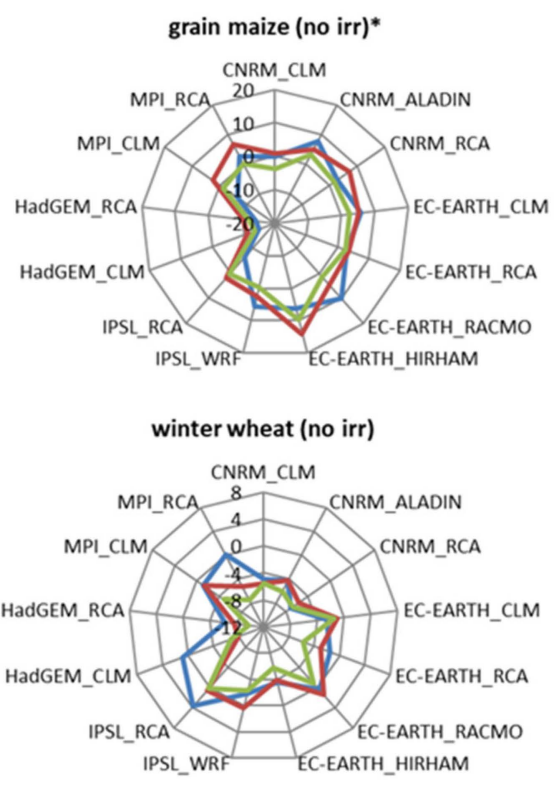

b)
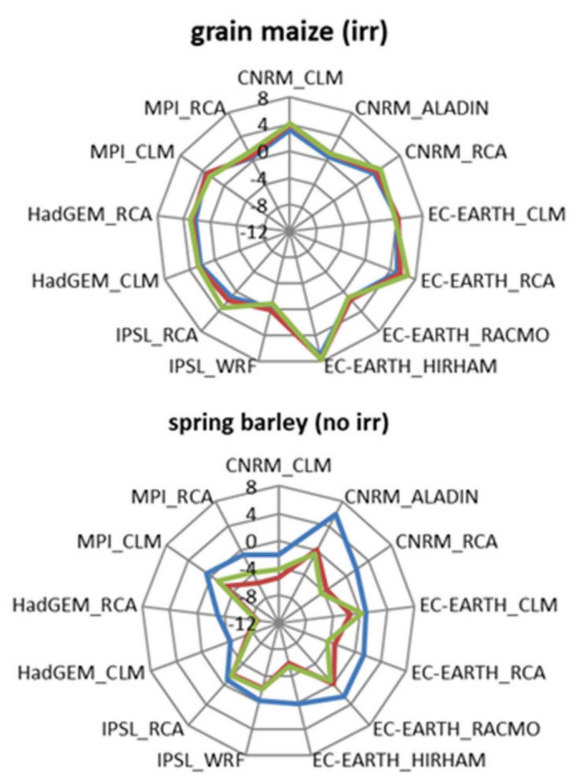

\section{Poysdorf - RCP 8.5}
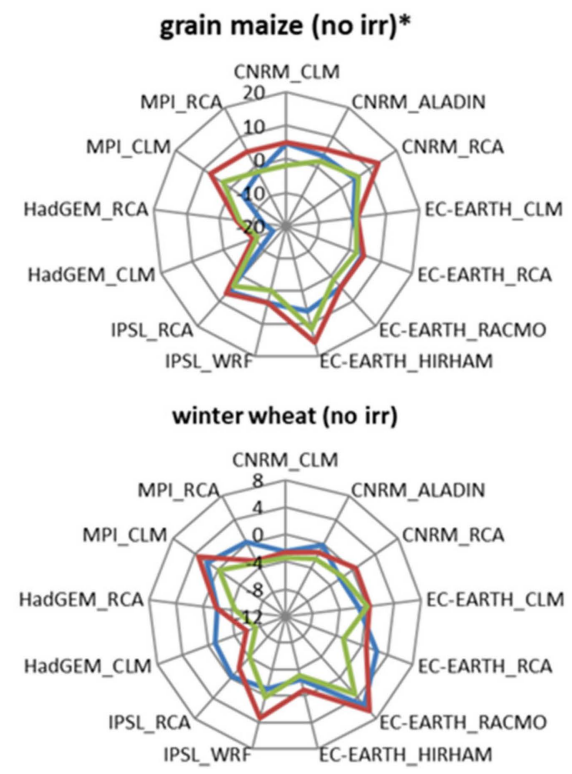

$$
\text { - soil } 1 \longrightarrow \text { soil } 2 \longrightarrow \text { soil } 3
$$

Figure 3. Simulated mean yield differences (with respect to measured weather station data input, as percentages) for grain maize (optimal irrigated = irr; rainfed = no irr), spring barley (no irr), and winter wheat (no irr) grown in the three different soil classes (soil $1=$ blue, soil $2=$ red, soil $3=$ green) for 13 ÖKS projections ((a) RCP 4.5, (b) RCP 8.5) for 1981-2010 at Poysdorf weather station locations). * Other axes numbered due to outliers $(-20$ to +20$)$. 
Table 3. Pearson's correlation coefficients of evapotranspiration (ET), transpiration (T), evaporation (E) compared with relative yield differences (projections vs. ZAMG simulations) for grain maize (optimal irrigated = irr; rainfed = no irr), spring barley (no irr), and winter wheat (no irr) in the three different soil classes for RCP 4.5 (a) and RCP 8.5 (b), 1981-2010 in Poysdorf.

\begin{tabular}{|c|c|c|c|c|c|c|}
\hline & \multicolumn{3}{|c|}{ RCP 4.5} & \multicolumn{3}{|c|}{ RCP 8.5} \\
\hline & ET & $\mathbf{T}$ & $\mathrm{E}$ & ET & $\mathbf{T}$ & $\mathbf{E}$ \\
\hline & \multicolumn{6}{|c|}{ maize-irr } \\
\hline soil 1 & 0.43 & $0.58 *$ & 0.17 & 0.32 & $0.59 *$ & 0.02 \\
\hline soil 2 & 0.43 & $0.65 *$ & 0.18 & 0.33 & $0.58 *$ & 0.07 \\
\hline \multirow[t]{2}{*}{ soil 3} & 0.06 & $0.70 *$ & -0.26 & 0.36 & $0.57 *$ & 0.12 \\
\hline & \multicolumn{6}{|c|}{ maize-no irr } \\
\hline soil 1 & 0.75 * & $0.88 *$ & $0.69 *$ & 0.83 * & $0.81 *$ & 0.73 * \\
\hline soil 2 & 0.85 * & $0.95 *$ & $0.63 *$ & 0.88 * & $0.91 *$ & 0.71 * \\
\hline \multirow[t]{2}{*}{ soil 3} & 0.85 * & $0.94 *$ & $0.69 *$ & 0.91 * & $0.89 *$ & 0.84 * \\
\hline & \multicolumn{6}{|c|}{ spring barley } \\
\hline soil 1 & 0.93 * & $0.63 *$ & -0.23 & 0.77 * & $0.84 *$ & $0.59 *$ \\
\hline soil 2 & 0.86 * & 0.43 & -0.07 & 0.60 * & $0.79 *$ & 0.45 \\
\hline \multirow[t]{2}{*}{ soil 3} & 0.88 * & 0.53 & -0.01 & 0.68 * & 0.80 * & 0.56 * \\
\hline & \multicolumn{6}{|c|}{ winter wheat } \\
\hline soil 1 & 0.42 & $0.73 *$ & 0.51 * & 0.30 & $0.69 *$ & 0.40 \\
\hline soil 2 & 0.71 * & $0.92 *$ & 0.47 & 0.59 * & $0.88^{*}$ & 0.32 \\
\hline soil 3 & 0.56 * & $0.87 *$ & 0.30 & 0.62 * & 0.87 * & 0.43 \\
\hline
\end{tabular}

* Correlation is significant at the 0.05 level (2-tailed).

In Table A2, the mean, median, maximum, and minimum values, as well as the $10 \%$ and $90 \%$ percentiles are listed for all ÖKS15 outputs for Poysdorf. While the yield of maize was overestimated by using the weather inputs from the projections, spring barley and winter wheat showed lower yields on average (except for spring barely in soil 1 for RCP 8.5). The largest range was seen for rainfed maize. Differences between soil types were rather small within crops, except for rainfed maize in RCP 8.5.

\subsubsection{Uncertainties in Bad Gleichenberg, Baseline}

In Bad Gleichenberg, the yield differences between model inputs of weather station data and ÖKS15 projections were smaller for all three crops than for Poysdorf (Figure 4). Irrigated maize showed both an overestimation of up to 5\% (EC-EARTH_HIRHAM) and a yield depression of $-2 \%$ (IPSL_WRF, MPI_CLM). The differences between RCP 4.5 and RCP 8.5 were small, and the same trend was indicated. In the case of rainfed maize, soil 1, in particular, was characterized by greater yield losses. Here, too, HadGEM_CLM showed strong yield deviations for soil 1 that reached up to $-19 \%$. From sowing to harvest, $150 \mathrm{~mm}$ (RCP 8.5) less precipitation was projected than at the ZAMG weather station, especially in July and August, for which $-57 \mathrm{~mm}$ rainfall was predicted (RCP 8.5, not shown). Hardly any fluctuations were observed for spring barley, and all three soil classes showed small deviations. For winter wheat, significantly lower yields were found for all projections, and values of up to $-7 \%$ (RCP 4.5, soil 1: EC-EARTH_RCA and MPI_RCA; RCP 8.5, soil 1: MPI_RCA) were simulated. 
a)

Bad Gleichenberg - RCP 4.5
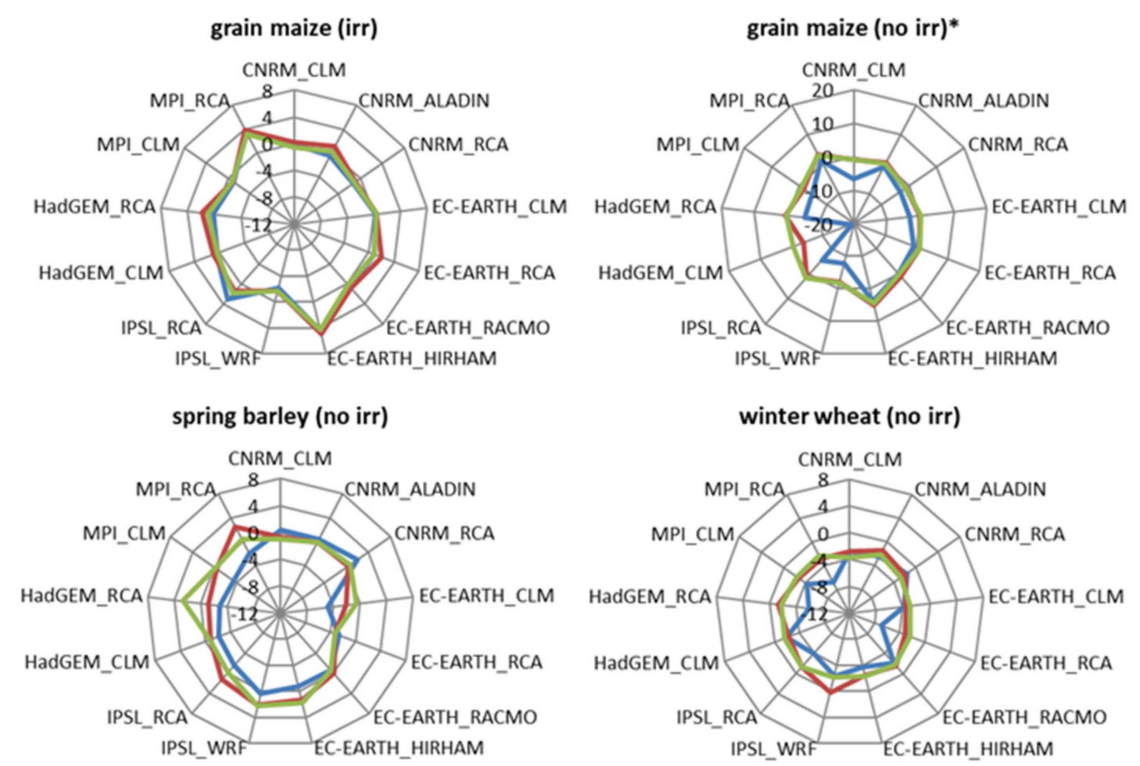

b)

\section{Bad Gleichenberg - RCP 8.5}
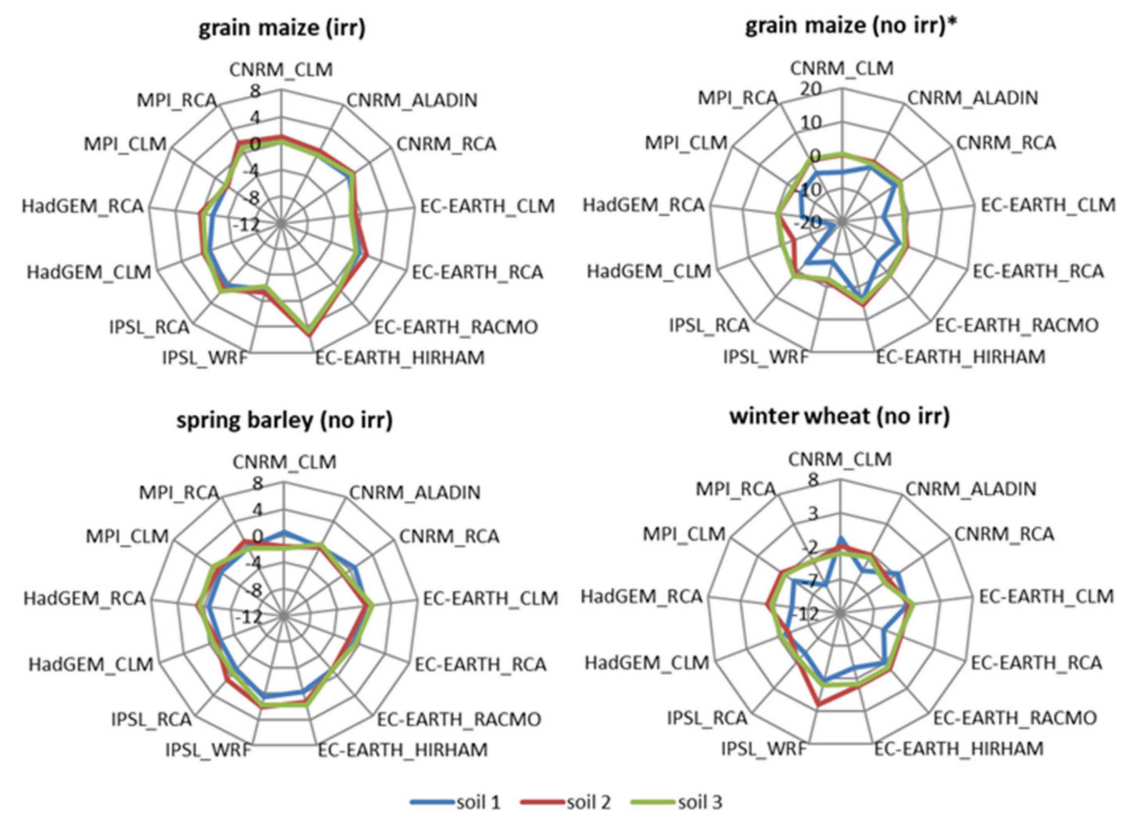

Figure 4. Simulated mean yield differences (with respect to measured weather station data input, as percentages) for grain maize (optimal irrigated = irr; rainfed = no irr), spring barley (no irr), and winter wheat (no irr) grown in the three soil classes (soil $1=$ blue, soil $2=$ red, soil $3=$ green) for 13 ÖKS projections ((a) RCP 4.5, (b) RCP 8.5) for 1981-2010 at Bad Gleichenberg weather station locations. * Other axes numbered due to outliers $(-20$ to +20$)$.

Looking at the correlation analysis between ET, T, E and the relative yield deviation for Bad Gleichenberg (Table 4), there was a positive ET correlation in both emission scenarios for irrigated maize, with values of up to $64 \%$ attained (RCP 4.5), but no significant values for T and E, except for soil 3 (RCP 4.5: 58\%; RCP 8.5: 57\%). The relationships of ET, T, and E with the yield variability of rainfed maize were, as in Poysdorf, well expressed in Bad Gleichenberg, showing strong, positive linear trends. ET and T values of up to 0.91 and $\mathrm{E}$ values of up to 0.80 were achieved. For spring barley, a strong correlation between $\mathrm{T}$ 
and yield fluctuation was observed (up to 80\%), while ET and E showed no significant correlations. Winter wheat showed weaker correlations, which were not significant for ET and $\mathrm{E}$, while $\mathrm{T}$ reached values of up to $79 \%$ for soil 2 . The other two soil types, 1 and 3 , did not show any significant values.

Table 4. Pearson's correlation coefficients of evapotranspiration (ET), transpiration (T), evaporation (E) compared with relative yield differences (projections vs. ZAMG simulations) for grain maize (optimal irrigated = irr; rainfed = no irr), spring barley (no irr), and winter wheat (no irr) in the three different soil classes for RCP 4.5 (a) and RCP 8.5 (b), 1981-2010 in Bad Gleichenberg.

\begin{tabular}{|c|c|c|c|c|c|c|}
\hline & \multicolumn{3}{|c|}{$\mathrm{RCP} 4.5$} & \multicolumn{3}{|c|}{ RCP 8.5} \\
\hline & ET & $\mathrm{T}$ & $\mathrm{E}$ & ET & $\mathbf{T}$ & E \\
\hline & \multicolumn{6}{|c|}{ maize-irr } \\
\hline soil 1 & $0.61 *$ & 0.26 & 0.41 & 0.54 & 0.35 & 0.48 \\
\hline soil 2 & $0.57^{*}$ & 0.44 & 0.46 & $0.61 *$ & 0.39 & 0.53 \\
\hline \multirow[t]{2}{*}{ soil 3} & 0.64 * & 0.36 & 0.58 * & 0.60 * & 0.45 & 0.57 * \\
\hline & \multicolumn{6}{|c|}{ maize-no irr } \\
\hline soil 1 & $0.91 *$ & 0.91 * & 0.68 * & 0.89 * & 0.88 * & 0.80 * \\
\hline soil 2 & $0.78 *$ & $0.65 *$ & 0.74 * & $0.82 *$ & 0.60 * & 0.80 * \\
\hline \multirow[t]{2}{*}{ soil 3} & 0.64 * & 0.34 & 0.60 * & 0.63 * & 0.40 & 0.59 * \\
\hline & \multicolumn{6}{|c|}{ spring barley } \\
\hline soil 1 & 0.10 & $0.80 *$ & -0.18 & 0.51 & 0.80 * & 0.35 \\
\hline soil 2 & 0.38 & $0.61 *$ & 0.33 & 0.37 & 0.38 * & 0.34 \\
\hline \multirow[t]{2}{*}{ soil 3} & 0.03 & 0.71 * & -0.05 & 0.10 & 0.46 & 0.05 \\
\hline & \multicolumn{6}{|c|}{ winter wheat } \\
\hline soil 1 & -0.19 & 0.40 & 0.17 & -0.09 & 0.63 * & 0.26 \\
\hline soil 2 & 0.25 & $0.56^{*}$ & 0.16 & 0.31 & 0.79 * & 0.21 \\
\hline soil 3 & -0.09 & 0.54 & -0.16 & -0.06 & 0.40 & -0.10 \\
\hline
\end{tabular}

Overall, in terms of ÖKS15 deviations, irrigated maize was slightly overestimated, and rainfed maize was only overestimated for soils 2 and 3 (Table A2). The percentiles showed significantly smaller ranges in both emission scenarios than in Poysdorf. Spring barley and winter wheat were also simulated with lower yields (the exception spring barley soil 3, RCP 4.5 and 8.5). Within crops, the differences between soils were small; the largest deviations were observed for the sandy type soil 1.

\subsubsection{Uncertinates in Kremsmünster, Baseline}

In contrast to the other two locations, Kremsmünster showed very small yield deviations between ÖKS projections and ZAMG input data for all three crops (Figure 5). Since rainfall variations did not have such a large effect in humid regions, the simulations also showed a low level of variance for rainfed maize. The only exception was HadGEM_CLM for soil class 1 ( $-8 \%$ for RCP 8.5$)$. The correlation between $\mathrm{T}$ and the relative yield deviation was especially high for rainfed maize and spring barley, reaching values of over $90 \%$ (RCP 4.5 , soil 1) (Table 5). For irrigated maize and winter wheat, a correlation between the two variables was only found for soil types 1 and 3 (except for winter wheat in RCP 8.5). 
a)

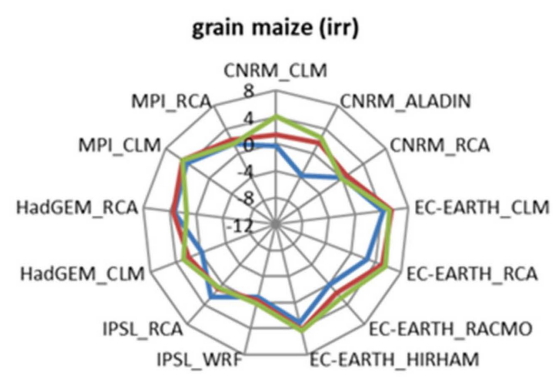

spring barley (no irr)

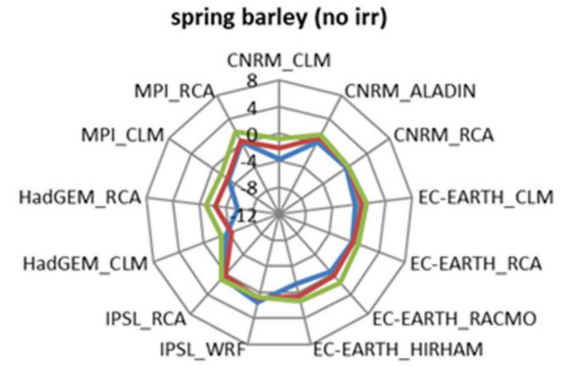

Kremsmünster-RCP 4.5
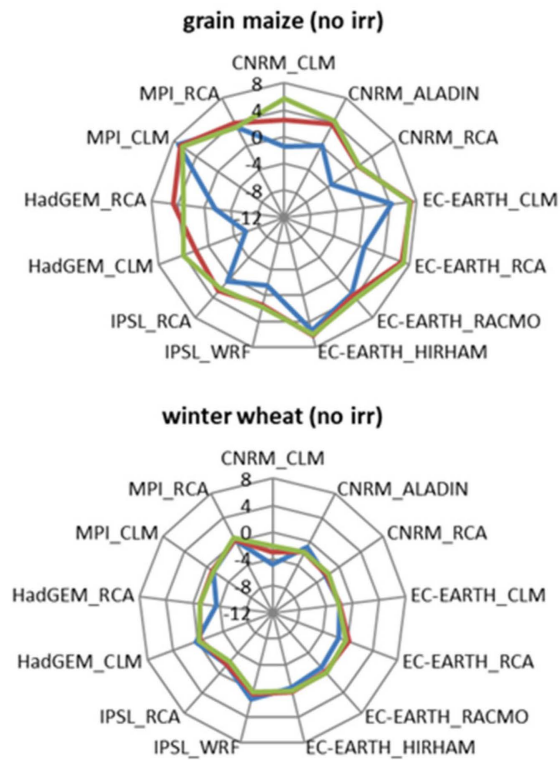

b)

\section{Kremsmünster-RCP 8.5}

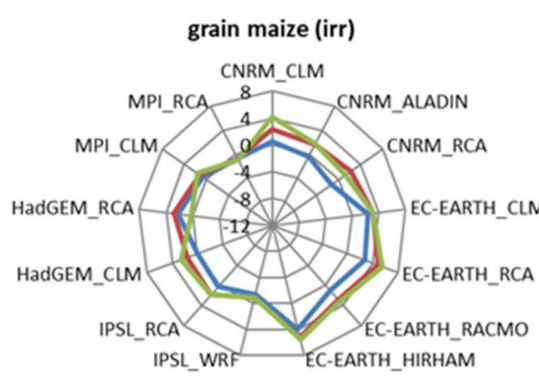

spring barley (no irr)

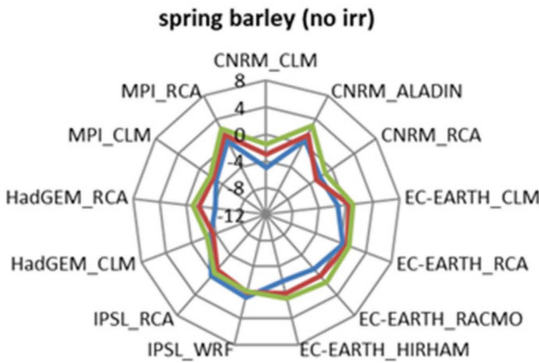

grain maize (no irr)
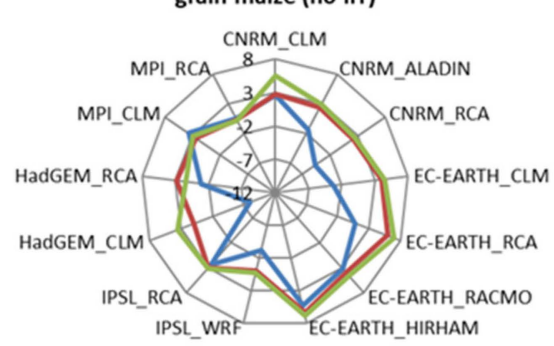

winter wheat (no irr)

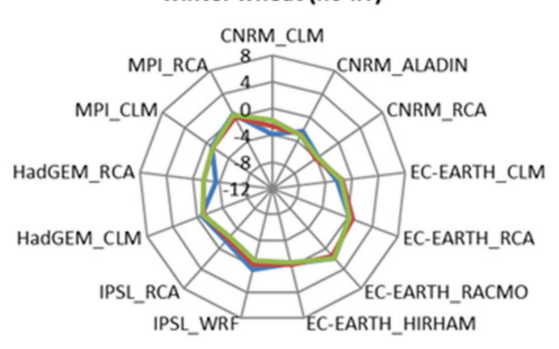

-soil $1-$ soil $2-$ soil 3

Figure 5. Simulated mean yield differences (with respect to measured weather station data input, as percentages) for grain maize (optimal irrigated $=$ irr; rainfed $=$ no irr), spring barley (no irr), and winter wheat (no irr) grown in the three different soil classes (soil $1=$ blue, soil $2=$ red, soil $3=$ green) for 13 ÖKS projections ((a) RCP 4.5, (b) RCP 8.5) for 1981-2010 at the Kremsmünster weather station locations. 
Table 5. Pearson's correlation coefficients of evapotranspiration (ET), transpiration (T), evaporation (E) compared with relative yield differences (projections vs. ZAMG simulations) for grain maize (optimal irrigated = irr; rainfed = no irr), spring barley (no irr), and winter wheat (no irr) in the three different soil classes for RCP 4.5 (a) and RCP 8.5 (b); 1981-2010 in Kremsmünster.

\begin{tabular}{|c|c|c|c|c|c|c|}
\hline & \multicolumn{3}{|c|}{ RCP 4.5} & \multicolumn{3}{|c|}{ RCP 8.5} \\
\hline & ET & $\mathbf{T}$ & $\mathrm{E}$ & ET & $\mathbf{T}$ & $\mathbf{E}$ \\
\hline & \multicolumn{6}{|c|}{ maize-irr } \\
\hline soil 1 & 0.30 & $0.69 *$ & -0.30 & 0.18 & $0.56 *$ & -0.04 \\
\hline soil 2 & -0.18 & 0.50 & -0.36 & 0.08 & 0.46 & -0.08 \\
\hline \multirow[t]{2}{*}{ soil 3} & $-0.67^{*}$ & $0.68 *$ & $-0.76^{*}$ & -0.65 * & $0.59 *$ & -0.74 * \\
\hline & \multicolumn{6}{|c|}{ maize-no irr } \\
\hline soil 1 & $0.60 *$ & $0.92 *$ & -0.04 & 0.80 * & $0.90 *$ & 0.26 \\
\hline soil 2 & 0.17 & $0.57 *$ & 0.03 & 0.35 & 0.51 & 0.26 \\
\hline \multirow[t]{2}{*}{ soil 3} & $-0.57^{*}$ & $0.66^{*}$ & -0.66 * & -0.50 & $0.58^{*}$ & -0.60 * \\
\hline & \multicolumn{6}{|c|}{ spring barley } \\
\hline soil 1 & $0.67^{*}$ & $0.92 *$ & 0.52 & 0.53 & $0.84 *$ & 0.39 \\
\hline soil 2 & $0.66^{*}$ & 0.83 * & 0.54 & 0.49 & $0.79 *$ & 0.39 \\
\hline \multirow[t]{2}{*}{ soil 3} & $0.64 *$ & $0.74 *$ & 0.55 & 0.44 & $0.78 *$ & 0.34 \\
\hline & \multicolumn{6}{|c|}{ winter wheat } \\
\hline soil 1 & 0.26 & $0.55 *$ & -0.15 & 0.25 & 0.18 & 0.05 \\
\hline soil 2 & -0.06 & 0.47 & -0.23 & 0.03 & 0.25 & -0.04 \\
\hline soil 3 & 0.30 & 0.69 * & -0.30 & 0.02 & 0.04 & 0.01 \\
\hline
\end{tabular}

* Correlation is significant at the 0.05 level (2-tailed).

As expected, the deviations among the ÖKS projections were smaller than for the other two locations (Table A2). Grain maize was mainly overestimated, while lower yields were simulated for spring barley and winter wheat. The percentile range was higher for both maize simulations than for the two cereals.

One reason for the simulated yield deviations could be the global radiation data used for the model inputs. There were systematic differences between measured and scenariobased global radiation; however, the measured data had gaps. Thus, the percentage of measured global radiation data included in simulations was 32\% in Bad Gleichenberg, 93\% in Kremsmünster, and 25\% in Poysdorf across the entire time series (1981-2010). The missing data were completed with the help of regression analyses (see Section 2.3). This could have contributed to the simulated yields to some extent. The largest monthly differences in the radiation values between the weather stations and ÖKS15 projections were found for Bad Gleichenberg in April and May (ca. $+0.9 \mathrm{MJ} / \mathrm{m}^{2} / \mathrm{d}$ in ÖKS15) and for Poysdorf in June (ca. $+0.8 \mathrm{MJ} / \mathrm{m}^{2} / \mathrm{d}$ in ÖKS15) (not shown).

\subsection{Uncertainties Based on Emission Scenarios and Climate Models of the ÖKS15 Projections,} 2071-2100 vs. Baseline

To explain the sensitivity and uncertainties coming from the different climate change scenarios, the deviations in the simulated crop yields based on the different climate scenarios from 2071 to 2100 compared with the baseline data (same projection) are shown in Figure 6a, Figure 7a, and Figure 8a (RCP 4.5) and Figure 6b, Figure 7b, and Figure 8b (RCP 8.5). 
a)

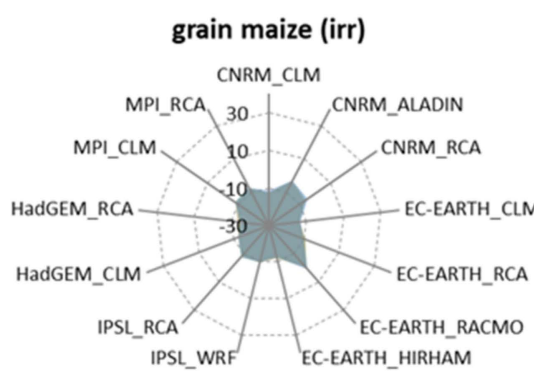

spring barley (no irr)

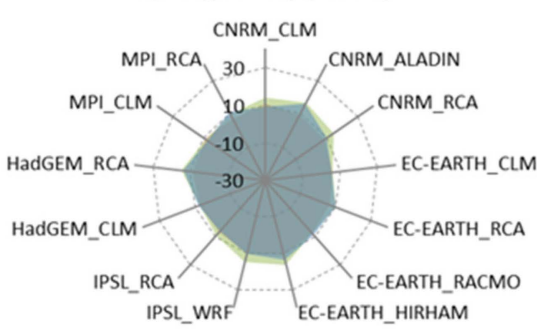

"nsoil 1 soil 2 =soil 3

b)

\section{Poysdorf - RCP 8.5}

grain maize (irr)

CNRM_CLM

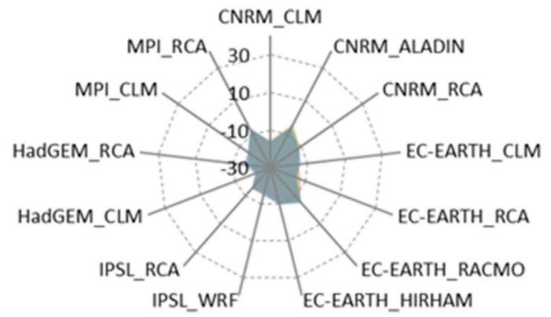

spring barley (no irr)

CNRM_CLM

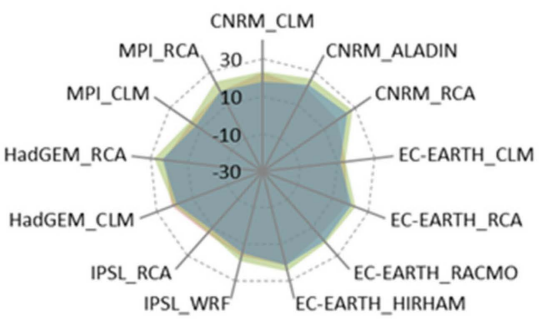

grain maize (no irr)

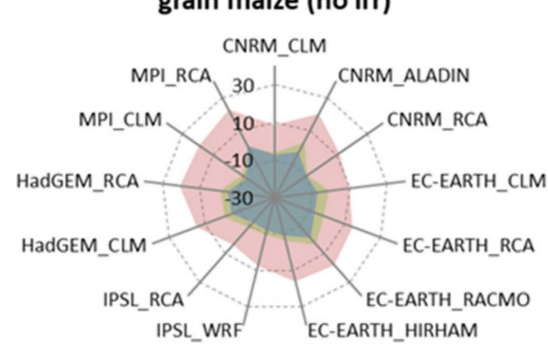

winter wheat (no irr)

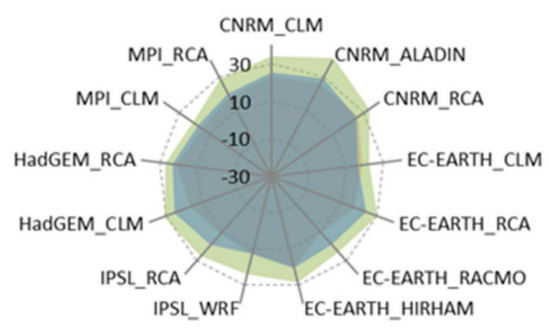

" soil 1 |n soil 2 || soil 3

Figure 6. ÖKS15 projection-based simulated yield differences (2071-2100 vs. 1981-2010) for grain maize (optimal irrigated $=$ irr; rainfed $=$ no irr), spring barley (no irr), and winter wheat (no irr) for three different soil classes (soil 1 = pink, soil 2 = green, soil $3=$ blue) $($ RCP 4.5 (a) and RCP 8.5 (b)) at Poysdorf weather station locations. 
a)

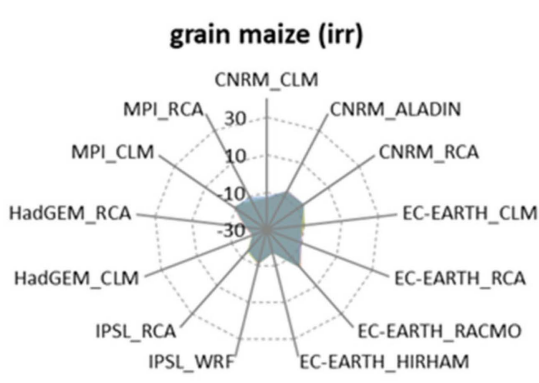

spring barley (no irr)

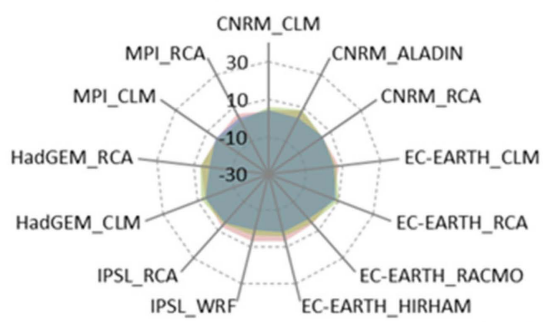

" soil 1 in soil 2 "n soil 3
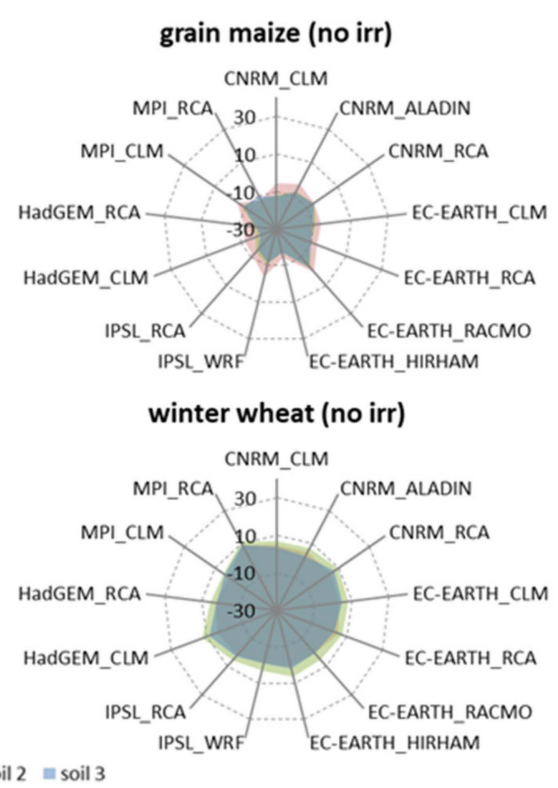

b)

Bad Gleichenberg - RCP 8.5
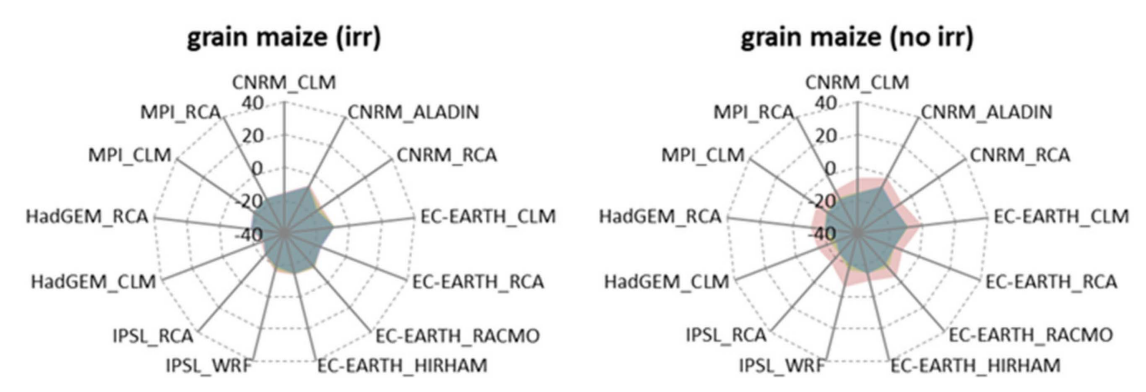

spring barley (no irr)

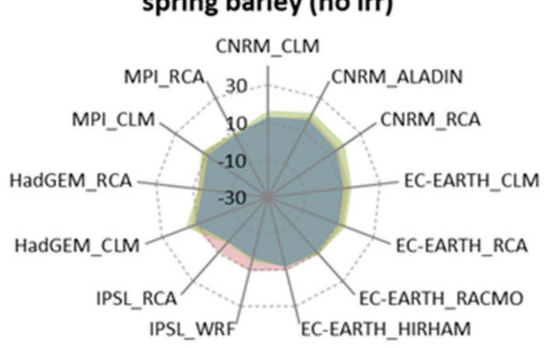

\section{winter wheat (no irr)}

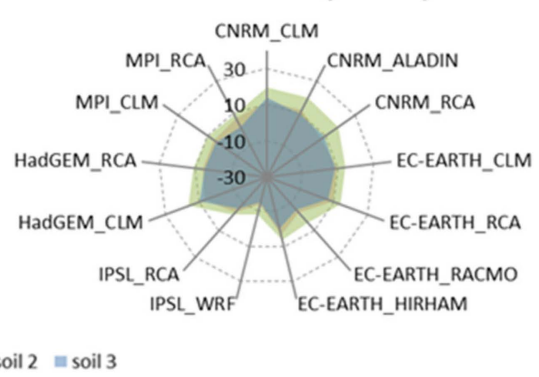

Figure 7. ÖKS15 projection-based simulated yield differences (2071-2100 vs. 1981-2010) for grain maize (optimal irrigated = irr; rainfed = no irr), spring barley (no irr), and winter wheat (no irr) for the three different soil classes (soil 1 = pink, soil 2 = green, soil $3=$ blue) $(\mathrm{RCP} 4.5$ (a) and RCP 8.5 (b)) at the Bad Gleichenberg weather station locations. 
a)
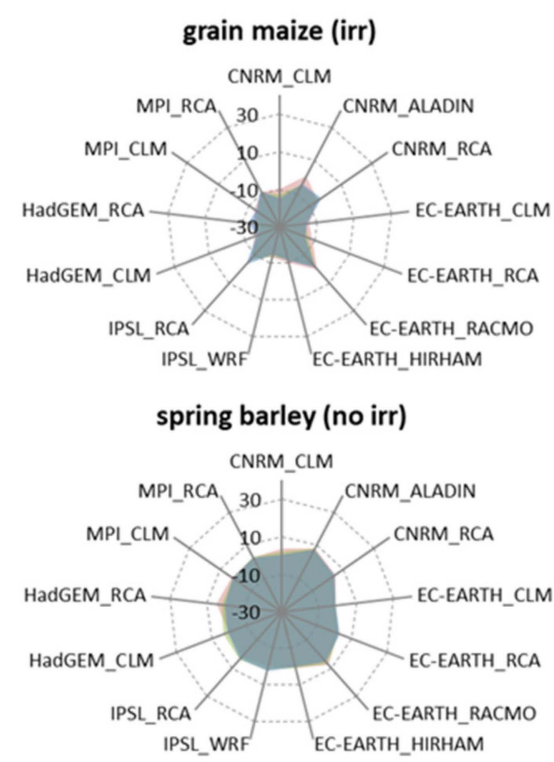

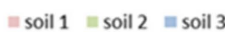

b)

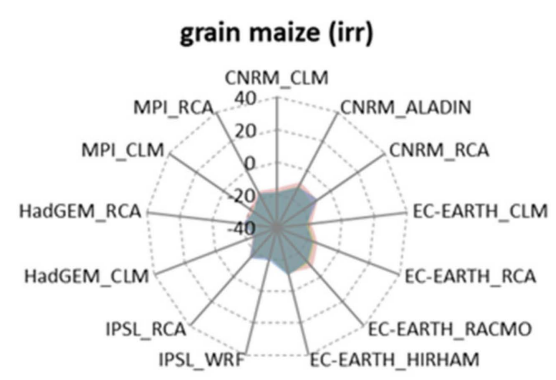

spring barely (no irr)

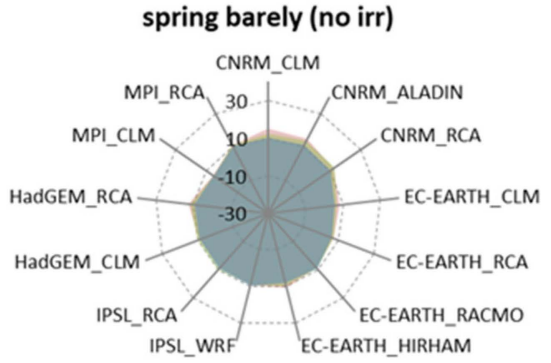

Kremsmünster-RCP 8.5

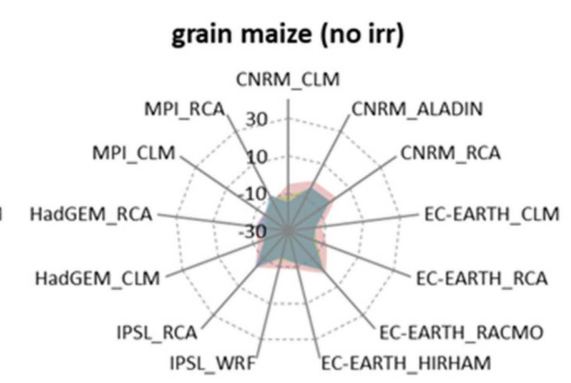

winter wheat (no irr)

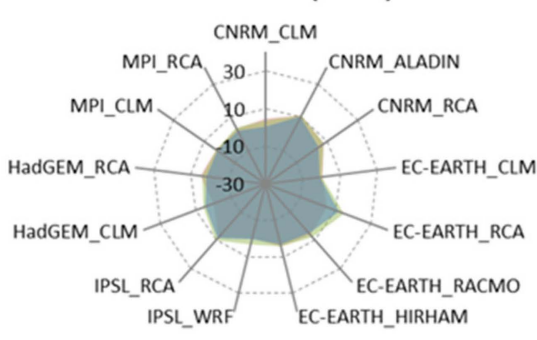

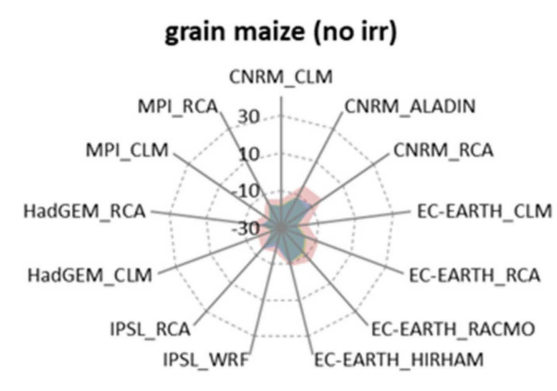

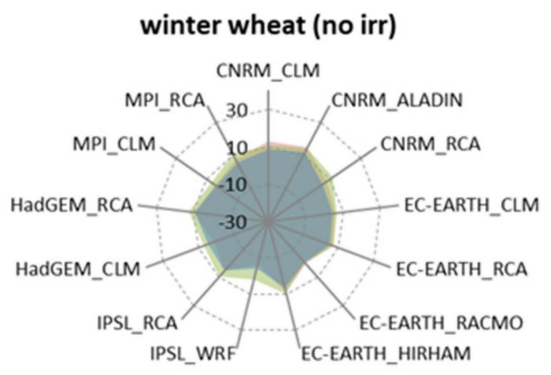

"nsoil 1 " soil 2 = soil 3

Figure 8. ÖKS15 projection-based simulated yield differences (2071-2100 vs. 1981-2010) for grain maize (optimal irrigated $=$ irr; rainfed $=$ no irr), spring barley (no irr), and winter wheat (no irr) growth in three different soil classes (soil $1=$ pink, soil $2=$ green, soil $3=$ blue $)($ RCP 4.5 (a) and RCP $8.5(\mathbf{b}))$ at Kremsmünster.

\subsubsection{Uncertainties in Poysdorf, 2071-2100 vs. Baseline}

In Poysdorf, a clear decreasing trend in irrigated maize yields was observed (Figure 6) for the 2071-2100 projections. This was due to a strongly reduced $\mathrm{CO}_{2}$ fertilization effect for $\mathrm{C} 4$ crops, with a further rise in $\mathrm{CO}_{2}$ levels, combined with a shorter growing period for the specific simulated maize cultivar due to the warming trend. Except for CNRM_ALADIN and EC-EARTH_RACMO, the decreases were greater than $6 \%$ in RCP 4.5 and $7 \%$ in RCP 8.5 , respectively. In six RCP 4.5 models and in nine RCP 8.5 models, a yield depression of greater than $10 \%$ was simulated. These decreases showed similar trends for all three 
soil classes. The mean and median values across all models were $-9 \%$ for RCP 4.5 and $-13 \%$ for RCP 8.5 , and the range between percentiles of 10 and $90 \%$ was around $10 \%$ (Table A3). Only rainfed maize at the driest site behaved differently. Here, a yield increase was predicted for soil 1, with increases of up to 28\% in RCP 4.5 (HadGEM_RCA) and 23\% in RCP 8.5 (MPI_RCA). This occurred because both scenarios were projected to have higher precipitation totals by the end of the century, which would mainly benefit sandy soil 1 due to its low soil water-holding capacity. For the other two soil classes, a yield decrease was observed, especially for EC-EARTH_HIRHAM in RCP 4.5 and IPSL_WRF, IPSL_RCA in RCP 8.5 ( $-12 \%$ yield loss). The ranges between the two percentiles $(10 \%$ and $90 \%)$ for the three soils were similar to those observed for irrigated maize (Table A3). At the end of the century, spring barley and winter wheat (C3 crops) showed higher yields for all three soil classes, especially in RCP 8.5. The $\mathrm{CO}_{2}$ fertilization effect predicted to occur due to increasing atmospheric $\mathrm{CO}_{2}$ levels, which was considered in the crop model, was shown to contribute significantly to this trend for both $\mathrm{C} 3$ crops. The mean increase in the spring barley yield across all 13 projections was very high in Poysdorf, with values of $10 \%$ (RCP 4.5) and 20\% (RCP 8.5), respectively (Table A3). The situation was similar for the winter wheat yield: $+14 \%$ in RCP 4.5 and $+23 \%$ in RCP 8.5 , respectively. Five projections, CNRM_CLM, CNRM_ALADIN, EC-EARTH_HIRHAM, HadGEM_CLM, and HadGEM_RCA, simulated yield increases in soil class 2 of more than $20 \%$ for spring barley in RCP 8.5, and, for winter wheat, values of over $30 \%$ were calculated.

\subsubsection{Uncertainties in Bad Gleichenberg, 2071-2100 vs. Baseline}

A clear decreasing trend in irrigated maize yields, also observed in Bad Gleichenberg, was more pronounced than in Poysdorf (Figure 7). The IPSL_WRF, HadGEM_CLM, and HadGEM_RCA projections showed the largest negative deviations, ranging from $-22 \%$ in RCP 4.5 to $-26 \%$ in RCP 8.5 (soils 2 and 3). In contrast, EC-EARTH_RACMO and CNRM_ALADIN showed the smallest changes, ranging from $0.7 \%$ (RCP 4.5 , soil 1) to $-12 \%$ (RCP 8.5, soil 3). In particular, EC-EARTH_RACMO in RCP 4.5 simulated hardly any changes. While in Poysdorf the yield of rainfed maize on soil 1 could increase, a clear decrease in yield was shown for Bad Gleichenberg for all three soil classes (but a lesser decrease for soil 1; see above), and this was more pronounced in RCP 8.5. HadGEM_CLM projected the largest decrease of up to $-26 \%$ (RCP 8.5 , soil 3). The range in percentage targets $(10 \%$ and $90 \%$ ) of about $10 \%$ was similar for both maize simulations (Table A3). As in Poysdorf, spring barley and winter wheat showed clear increases in yield in Bad Gleichenberg, on average around 3\% to 13\% (Table A3). While winter wheat showed a yield stagnation or increase in RCP 4.5, RCP 8.5 also contained projections showing a lower winter wheat yield, namely, EC-EARTH_RACMO, IPSL_WRF, and IPSL_RCA. These deviations in winter wheat occurred because the crop model did not always find the minimum condition for a sowing date in autumn, and thus, the year was not simulated. However, in practice, this normally occurs when reseeding is carried out to safeguard the crop. The main causes for missing sowing in the simulation were an excessively dry or warm autumn within the sowing window. If the few failing years were omitted from the 30-year study period, the differences decreased significantly. Thus, only 22 years were simulated in EC-EARTH_RACMO and IPSL_WRF, and 24 years in IPSL_RCA, instead of 30 years.

\subsubsection{Uncertainties in Kremsmünster, $2071-2100$ vs. Baseline}

Similar to Bad Gleichenberg, a yield reduction was simulated for irrigated and rainfed maize by the end of the century relative to the baseline (Figure 8). Eight projections in RCP 4.5 and ten in RCP 8.5 reached a yield reduction of 10\%; in RCP 8.5, the decrease extended to over 25\% (HadGEM_CLM). The range of percentages of yield reduction (between 10\% and $90 \%$ ) was high ( $>10 \%$ ), and the median yield reduction of over $17 \%$ was the highest of all three regions (RCP 4.5, soil 2) (Table A3). Yield increases were simulated for spring barley and winter wheat. The mean increases in spring barley were 3\% (RCP 4.5) and 10\% 
(RCP 8.5), respectively; and in winter wheat, they were 5\% in RCP 4.5 and $6 \%$ in RCP 8.5 , respectively (Table A3, mean value across all three soils). The only two projections, where less winter wheat was achieved in RCP 8.5, were EC-EARTH_RACMO and IPSL_WRF. Again, fewer years were simulated: 18 years in EC-EARTH_RACMO and 25 years in IPSL_WRF.

3.3. Uncertainties Based on Crop Yield Differences between the RCP 4.5 and RCP 8.5 Projections, 2071-2100

To explore the sensitivity to uncertainties in the emission scenarios, Figures 9-11 show the differences in the simulated yield (as percentages) between RCP 4.5 and RCP 8.5 for the 2071-2100 period using soil 2 as an example. Table A4 gives a summary of the descriptive statistics for all projections for all three simulated soils in Poysdorf, Bad Gleichenberg, and Kremsmünster.

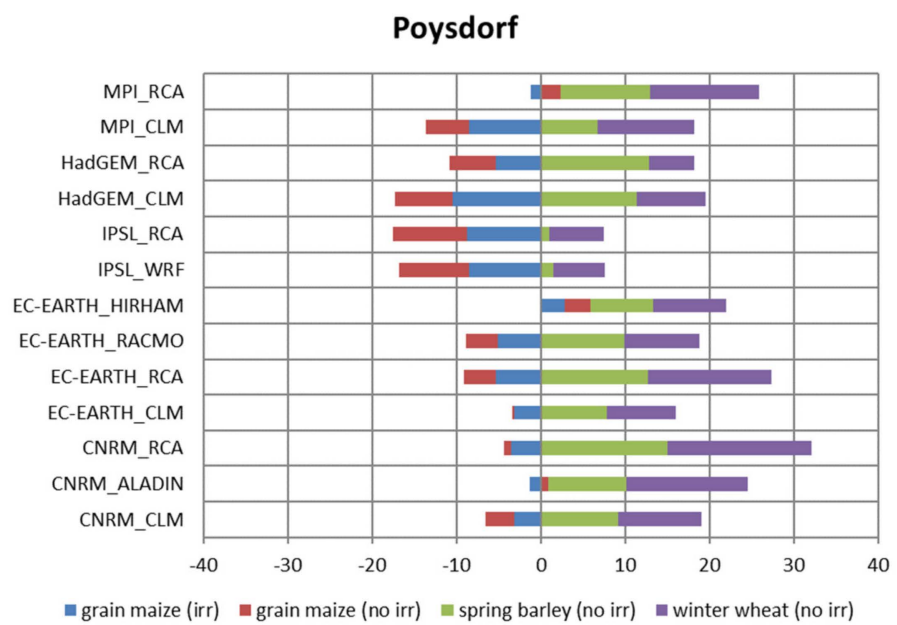

Figure 9. Yield differences (\%) among ÖKS15 projections for RCP 8.5 vs. RCP 4.5 for the 2071-2100 period for grain maize (optimal irrigated = irr; rainfed = no irr), spring barley (no irr), and winter wheat (no irr) grown in soil class 2 in Poysdorf.

\section{Bad Gleichenberg}

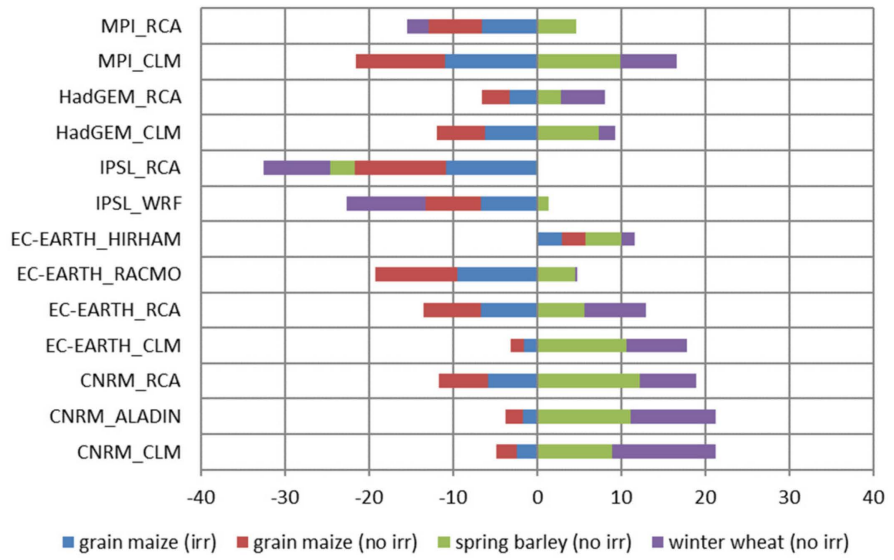

Figure 10. Yield differences (\%) for ÖKS15 projections for RCP 8.5 vs. RCP 4.5 for the period 2071-2100 for grain maize (optimal irrigated = irr; rainfed = no irr), spring barley (no irr), and winter wheat (no irr) grown in soil class 2 in Bad Gleichenberg. 


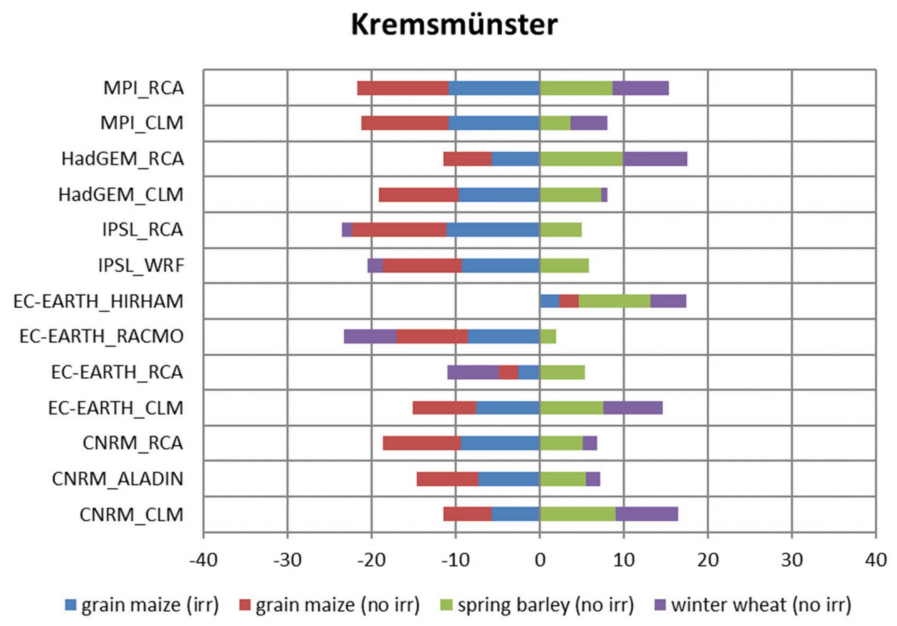

Figure 11. Yield differences (\%) in ÖKS15 projections for RCP 8.5 vs. RCP 4.5 for the 2071-2100 period for grain maize (optimal irrigated = irr; rainfed = no irr), spring barley (no irr), and winter wheat (no irr) grown in soil class 2 in Bad Gleichenberg.

\subsubsection{Uncertainties in Poysdorf, 2071-2100, RCP 8.5 vs. RCP 4.5}

In Poysdorf, winter wheat and spring barley showed higher yields under RCP 8.5 for all projections for soil 2 (Figure 9). The overall positive yield impacts were mainly related to the assumed $\mathrm{CO}_{2}$-fertilization effect for $\mathrm{C} 3$ crops. The yield difference was around $+8 \%$ for both crops (Table A4, mean value across all three soils). However, for grain maize, opposing yield trends were observed, and RCP 4.5 mostly showed higher values, except for EC-EARTH_HIRHAM (+3\% for soil 2). The annual average temperature increase in EC-EARTH_HIRHAM was approximately $0.5^{\circ} \mathrm{C}$ lower than in the other projections, thus allowing a longer growing period for the simulated cultivar, leading to a positive yield effect. Both emission scenarios showed greater levels of precipitation, especially in the first four months, and the level was considerably higher for RCP 8.5, especially in January and February. Comparing the two different emission scenarios in terms of the baseline period vs. the end of the century, the decrease in transpiration was several times higher for maize cultivation than for cereals, which is due to a shortening of the growing period rather than an increase in water use efficiency due to $\mathrm{CO}_{2}$-fertilization. This was amplified in RCP 8.5 and thus explained the lower yield compared to RCP 4.5. A further exception was rainfed maize grown in soil 1, which presented higher yields by up to $+3.8 \%$ in the RCP 8.5 projections (Table A4). The higher water supply in RCP 8.5 could be better utilized in sandy soil, leading to an increase in yield.

\subsubsection{Uncertainties in Bad Gleichenberg, 2071-2100 RCP 8.5 vs. RCP 4.5}

As in Poysdorf, cereals cultivated in Bad Gleichenberg had yield increases in RCP 8.5, whereas maize had a higher yield in RCP 4.5 (Figure 10). There were only a few exceptions: in Bad Gleichenberg, the RCP 4.5 projections showed a higher spring barley yield in IPSL_RCA, and for winter wheat in IPSL_WRF, IPSL_RCA, and MPI_RCA (Figure 10). An explanation for this can be found in the simulated soil water balance parameters. Two projections, IPSL_WRF and IPSL_RCA, showed large drainage differences between the RCP 4.5 and RCP 8.5 simulations during the growing season, and for RCP 8.5, these were greater than $110 \mathrm{~mm}$ (spring barley) and $135 \mathrm{~mm}$ (winter wheat). At the same time, the two RCP 8.5 projections showed very low transpiration values (spring barley: around $120 \mathrm{~mm}$ for the entire vegetation period and winter wheat: $105 \mathrm{~mm}$ ). For MPI_RCA, the drainage values of RCP 8.5 were similar to those found in the other scenarios, but transpiration was much lower compared to RCP 4.5: $-50 \mathrm{~mm}$ across the whole winter wheat vegetation period (not shown). For maize, EC-EARTH_HIRHAM was also an exception as it had a higher yield at RCP 8.5. The main reason for this was that, in Bad Gleichenberg, there was a lower precipitation level and cooler temperatures from May to September in RCP 4.5 
compared with the other projections, while higher precipitation totals were forecast in RCP 8.5 during this period.

The mean differences between RCP 4.5 and RCP 8.5 were smaller in Bad Gleichenberg than in Poysdorf. Thus, yield increases of approximately $6 \%$ for spring barley and $2 \%$ for winter wheat were simulated across all three soil classes (Table A4). These values were much higher in Poysdorf ( $+9 \%$ for spring barley and $+8 \%$ for winter wheat) (Table A4). While spring barley showed a range (between $10 \%$ and $90 \%$ ) of $7 \%$, winter wheat presented the highest value of $15 \%$ in Bad Gleichenberg. An average yield increase of 5\% was simulated for maize for RCP 4.5, and the range (between 10\% and 90\%) was around $8 \%$, similar to that found for Poysdorf (Table A4).

\subsubsection{Uncertainties in Kremsmünster, 2071-2100, RCP 8.5 vs. RCP 4.5}

Whereas the projections in Kremsmünster for spring barley and winter wheat mainly showed an increase in RCP 8.5, EC-EARTH_RACMO, EC-EARTH_RCA, IPSL_WRF, and IPSL_RCA showed higher yields for winter wheat in RCP 4.5 (Figure 11). Looking closer to the soil water balance, EC-Earth_RACMO had the lowest transpiration rate of all scenarios during the winter wheat season, with $92 \mathrm{~mm}$ (RCP 8.5), which was much higher in RCP 4.5, by $147 \mathrm{~mm}$ (not shown). As in Bad Gleichenberg, IPSL_WRF also showed very high drainage values and low transpiration values for RCP 8.5 (not shown). The yield difference with IPSL_RCA was only $1 \%$ and the $9 \mathrm{~mm}$ lower transpiration value was decisive. The simulated maize yield was higher for RCP 4.5 in all projections (Figure 11), reaching mean yield increase values above 10\% (IPSL_RCA, HadGEM_CLM, MPI_CLM). However, one exception was EC-EARTH_HIRHAM, where stagnation or a slight increase in yield was calculated for RCP 8.5. Again, the increase in the annual average temperature with ECEARTH_HIRHAM was about $0.5^{\circ} \mathrm{C}$ lower than in the other projections, due to a longer growing season, leading to a positive yield effect. Both emission scenarios showed more precipitation, especially in the first four months, and the level was significantly higher in RCP 8.5.

\subsection{Aggregated ÖKS15 Projections and the Sensitivity of Crop Model Results in Regard to the Spatial Resolution}

Tables 6 and 7 show the yield for the three selected ÖKS15 scenarios in RCP 4.5 aggregated (see methods) for the baseline and 2071-100 periods for the crops studied in soil 1 as follows: $1 \mathrm{~km}$ weather input data vs. 5, 11, and $21 \mathrm{~km}$ aggregated data. The deviations are presented as percentages with respect to the results for the $1 \mathrm{~km}$ resolution. Mean, median, maximum, and minimum values within the different spatial resolutions in RCP 4.5 for all three soil types are shown in Table A5. Compared to baseline values, the ensembles of the RCP 4.5 scenarios were about 2 to $2.5 \mathrm{~K}$ warmer, with two of them being more humid (EC_EARTH_RCA and IPS_RCA). In contrast, the annual mean precipitation in HadCEM_CLM was about 5\% less for 2071-2100 with respect to 1981-2010 (Figure 2).

\subsubsection{Results for the Baseline Period-RCP4.5}

Bad Gleichenberg showed the largest positive simulated grain yield deviations in EC_Earth_RCA between $1 \mathrm{~km}$ and $5 \mathrm{~km}, 11 \mathrm{~km}, 21 \mathrm{~km}$ on soil 1, with maize increasing by $7 \%$, spring barley by $3 \%$, and winter wheat by $1 \%$ on average of the aggregated scales. Only for maize, a significant increase in yield from the $5 \mathrm{~km}$ scale to $11 \mathrm{~km}$ and $21 \mathrm{~km}$, respectively, was observed (Table 6). In IPSL_RCA and HadGEM_CLM, the differences compared with aggregated data were rather small between $-2.1 \%$ and $+4.7 \%$ (Table A5). Kremsmünster and Poysdorf, on the other hand, showed yield stagnation or even depression in the aggregated input data-up to $-10 \%$ for winter wheat grown in Poysdorf (IPSL-RCA). The only exception here was irrigated maize in EC-EARTH-RCA, which achieved a yield increase of $+10 \%$ in Poysdorf (Table 6 ). HadGEM_CLM showed the smallest differences between non-aggregated and aggregated inputs for all three locations, and differences were particularly low in Bad Gleichenberg and Kremsmünster (Table A5). 
Table 6. Yield differences (\%) for maize (rainfed = no irr, optimally irrigated = irr), winter wheat, and spring barley (rainfed) grown on the sandy soil class 1; $1 \mathrm{~km}$ input data vs. 5, 11, and $21 \mathrm{~km}$ aggregated data for 3 ÖKS15 projections in RCP 4.5 (EC-Earth_RCA, IPSL_RCA and HadGEM_CLM) in Bad Gleichenberg, Kremsmünster, and Poysdorf for the 1981-2010 period. Differences in percentage compared with the results with a $1 \mathrm{~km}$ resolution.

\begin{tabular}{|c|c|c|c|c|c|c|c|c|c|}
\hline \multicolumn{10}{|c|}{ RCP 4.5 1981-2010 } \\
\hline & $\begin{array}{c}5 \\
\mathrm{~km}\end{array}$ & 11 & 21 & $\begin{array}{c}5 \\
\mathrm{~km}\end{array}$ & 11 & 21 & $\begin{array}{c}5 \\
\mathrm{~km}\end{array}$ & $\begin{array}{c}11 \\
\mathrm{~km}\end{array}$ & 21 \\
\hline & \multicolumn{3}{|c|}{ Bad Gleichenberg } & \multicolumn{3}{|c|}{ Kremsmünster } & \multicolumn{3}{|c|}{ Poysdorf } \\
\hline \multicolumn{10}{|c|}{ RCP 4.5, EC-EARTH_RCA } \\
\hline maize_no irr & 4.9 & 6.5 & 6.0 & -1.2 & -0.9 & -0.3 & 0.2 & 0.9 & 1.1 \\
\hline maize_irr & 7.3 & 9.8 & 8.7 & 4.4 & 4.6 & 5.0 & 5.8 & 10.4 & 10.9 \\
\hline spring barley & 1.6 & 1.7 & 1.8 & -1.1 & -1.2 & -2.0 & -1.0 & 0.1 & -0.3 \\
\hline winter wheat & 3.8 & 3.3 & 2.7 & 0.3 & 0.4 & 0.7 & -1.2 & -0.3 & 0.3 \\
\hline \multicolumn{10}{|c|}{ RCP 4.5, IPSL_RCA } \\
\hline maize_no irr & -2.4 & -0.6 & -0.8 & -2.7 & -2.5 & -1.9 & -1.6 & -1.5 & -1.7 \\
\hline maize_irr & 3.9 & 3.3 & 5.4 & -2.6 & -2.5 & -2.3 & -4.9 & 0.2 & -1.8 \\
\hline spring barley & 4.5 & 5.4 & 4.1 & -2.6 & -2.1 & -1.9 & -0.8 & 2.0 & 1.5 \\
\hline winter wheat & 2.5 & 1.8 & 1.8 & -1.2 & -1.2 & -1.0 & -10.4 & -9.0 & -9.2 \\
\hline \multicolumn{10}{|c|}{ RCP 4.5, HadGEM_CLM } \\
\hline maize_no irr & 0.4 & 1.2 & 1.1 & -0.3 & 0.2 & 0.5 & 0.2 & 1.5 & 0.5 \\
\hline maize_irr & -0.1 & -1.0 & 2.2 & 1.9 & 2.2 & 2.3 & -0.6 & 4.6 & 1.6 \\
\hline spring barley & 0.3 & 1.1 & 0.9 & -0.3 & 0.2 & -0.7 & 1.2 & 1.7 & 2.0 \\
\hline winter wheat & -0.3 & -1.0 & -0.9 & -1.5 & -1.3 & -1.0 & -2.8 & -3.8 & -3.4 \\
\hline
\end{tabular}

\subsubsection{Results for the 2071-2100 Period-RCP 4.5}

In the 2071-2100 period (Table 7), the simulated yield deviations on soil 1 between different aggregated datasets shifted compared with the baseline data (Table 6). For maize, the aggregated data simulated greater yields in all three regions with the exception of Poysdorf for rainfed maize in EC-EARTH_RCA (yield decrease up to $-2.9 \%$ ). Irrigated maize grown in Bad Gleichenberg presented the highest values in IPSL_RCA (up to +12\%). Spring barley and winter wheat showed hardly any changes (except for spring barley grown in Poysdorf for EC-EARTH_RCA: $+6 \%$ ). In general, the effects on all three soils were quite similar and indicate the same direction (Table A5). In Kremsmünster, soils 2 and 3 were outliers in winter wheat in RCP 4.5, EC-EARTH_RCA with yield reductions (Table A5). The reason for this was the higher drainage value during the growing season in the aggregated data $(+30 \mathrm{~mm}$, not shown).

For the RCP 8.5 scenario (Table 8 andTable 9), five different projections were selected, two of which had mid-range values (EC-Earth_CLM and EC-Earth_RACMO) with about $+2.5 \mathrm{~K}$ and a slight precipitation increase compared with the baseline. The third projection (IPSL_WRF) showed a precipitation increase of over $20 \%$ as well as a higher temperature by almost $4 \mathrm{~K}$. The last two were extreme scenarios with an annual temperature change of more than $5 \mathrm{~K}$ and precipitation changes of $+10 \%$ (HadGEM_RCA) and -10\% (HadGEM_CLM), respectively (Figure 2). 
Table 7. Yield differences $(\%)$ for maize (rainfed = no irr, optimally irrigated = irr), winter wheat, and spring barley (rainfed) grown on the sandy soil class 1; $1 \mathrm{~km}$ input data vs. 5, 11, and $21 \mathrm{~km}$ aggregated data for three ÖKS15 projections for RCP 4.5 (EC-Earth_RCA, IPSL_RCA and HadGEM_CLM) for Bad Gleichenberg, Kremsmünster, and Poysdorf for the 2071-2100 period. Differences in percentage for the results with a $1 \mathrm{~km}$ resolution.

\begin{tabular}{|c|c|c|c|c|c|c|c|c|c|}
\hline \multicolumn{10}{|c|}{ RCP 4.5 2071-2100 } \\
\hline & $\begin{array}{c}5 \\
\mathrm{~km}\end{array}$ & 11 & 21 & $\begin{array}{c}5 \\
\mathrm{~km}\end{array}$ & 11 & 21 & $\begin{array}{c}5 \\
\mathrm{~km}\end{array}$ & 11 & 21 \\
\hline & \multicolumn{3}{|c|}{ Bad Gleichenberg } & \multicolumn{3}{|c|}{ Kremsmünster } & \multicolumn{3}{|c|}{ Poysdorf } \\
\hline \multicolumn{10}{|c|}{ RCP 4.5, EC-EARTH_RCA } \\
\hline maize_no irr & -0.6 & 1.5 & 1.2 & 1.2 & 1.0 & 1.5 & -1.9 & -2.9 & -2.2 \\
\hline maize_irr & -0.3 & 1.9 & 1.4 & 3.7 & 3.5 & 3.9 & 0.3 & 1.2 & 1.5 \\
\hline spring barley & 2.0 & 1.4 & 1.7 & -1.7 & -2.6 & -1.8 & 5.3 & 5.7 & 5.8 \\
\hline winter wheat & -0.4 & 1.2 & 0.5 & 0.7 & 0.7 & 0.9 & 3.0 & 2.1 & 2.7 \\
\hline \multicolumn{10}{|c|}{ RCP 4.5, IPSL_RCA } \\
\hline maize_no irr & 7.7 & 9.1 & 8.9 & 0.6 & 0.9 & 1.6 & 0.5 & 3.1 & 2.0 \\
\hline maize_irr & 10.6 & 12.4 & 11.4 & 0.9 & 1.3 & 1.7 & 5.6 & 9.0 & 9.0 \\
\hline spring barley & -0.3 & -0.9 & -0.2 & 1.9 & 2.0 & 2.3 & 0.8 & 1.0 & 0.8 \\
\hline winter wheat & 3.4 & 3.6 & 3.4 & -1.3 & -1.4 & -0.9 & 1.0 & 1.4 & 1.3 \\
\hline \multicolumn{10}{|c|}{ RCP 4.5, HadGEM_CLM } \\
\hline maize_no irr & 3.2 & 6.4 & 4.9 & 3.0 & 3.2 & 3.3 & -0.4 & 1.6 & 1.5 \\
\hline maize_irr & 0.3 & 3.4 & 1.5 & 3.4 & 3.6 & 3.4 & 2.1 & 3.9 & 5.2 \\
\hline spring barley & 0.0 & 0.0 & -0.1 & -1.5 & -1.0 & -0.4 & -0.1 & -0.3 & 0.9 \\
\hline winter wheat & 0.9 & 0.2 & 0.3 & -0.9 & -0.4 & 0.0 & 1.0 & 0.8 & 1.2 \\
\hline
\end{tabular}

\subsubsection{Results for the Baseline Period-RCP 8.5}

Overall, the yield differences in the baseline (1981-2010) projection for soil 1 were smaller with RCP 8.5 (Table 8) than with RCP 4.5 (Table 6). Soils 2 and 3 showed even lower variations and ranged from $-2.7 \%$ to $+3.8 \%$ (mean value over the aggregated data) (Table A6). For soil 1, Poysdorf ( $-2.4 \%$ until $7.5 \%)$, but also Bad Gleichenberg ( $-2 \%$ until $3.2 \%$ ) (Table 8), mainly higher yields for the aggregated datasets compared with the $1 \mathrm{~km}$ reference were shown. In particular, rainfed maize stood out with a yield increase of up to $7.5 \%$ (HadGEM_CLM) simulated in Poysdorf, while irrigated maize showed hardly any differences (Table 8). Kremsmünster, on the other hand, showed even lower yield deviations from $-2.4 \%$ until $+2.9 \%$. A clear difference between rainfed and irrigated maize was observed here with HadGEM_CLM (+3\%).

\subsubsection{Results for the 2071-2100 Period-RCP 8.5}

The two EC-Earth projections showed hardly any changes between the different aggregated datasets for the 2071-2100 period (Table 9, Table A6). In IPSL, which included $+20 \%$ more annual precipitation compared with the baseline, winter wheat, in particular, stood out. In the aggregated datasets, yield increases of up to $8.8 \%$ in Kremsmünster and $6.9 \%$ in Bad Gleichenberg for soil 1 were calculated, respectively (Table 9). In the two extreme HadGEM projections, the weather input data presented hardly any yield differences, except for rainfed maize in Kremsmünster (HadGEM_CLM) with an increase of $4.3 \%$ (soil 1). The mean yield deviations within the different aggregated datasets were the smallest in RCP 8.5 2071-2100, ranging from $-3 \%$ (Kremsmünster, spring barley HadGEM_RCA) to $+5 \%$ (Kremsmünster, rainfed maize HADGEM_CLM) (Table A6). This was caused by wetter conditions in RCP 8.5 , which reduced the impact of the spatial precipitation variation of soil type-related drought stress risk. 
Table 8. Yield differences (\%) for maize (rainfed = no irr, optimally irrigated = irr), winter wheat, and spring barley (rainfed) grown on the sandy soil class 1; $1 \mathrm{~km}$ input data vs. 5, 11 and $21 \mathrm{~km}$ aggregated data for five ÖKS15 projections in RCP 8.5 (EC-Earth_CLM, EC-Earth_RACMO, IPSL_WRF, IPSL_RCA and HadGEM_RCA) in Bad Gleichenberg, Kremsmünster and Poysdorf for the 1981-2010 period. Differences in percentages compared with the results with a $1 \mathrm{~km}$ resolution.

\begin{tabular}{|c|c|c|c|c|c|c|c|c|c|}
\hline \multicolumn{10}{|c|}{ RCP 8.5 1981-2010 } \\
\hline & $\begin{array}{c}5 \\
\mathrm{~km}\end{array}$ & $\begin{array}{c}11 \\
\mathbf{k m}\end{array}$ & $\begin{array}{c}21 \\
\mathrm{~km}\end{array}$ & $\begin{array}{c}5 \\
\mathrm{~km}\end{array}$ & $\begin{array}{c}11 \\
\mathbf{k m}\end{array}$ & $\begin{array}{c}21 \\
\mathrm{~km}\end{array}$ & $\begin{array}{c}5 \\
\mathrm{~km}\end{array}$ & $\begin{array}{c}11 \\
\mathrm{~km}\end{array}$ & $\begin{array}{r}21 \\
\mathrm{~km}\end{array}$ \\
\hline & \multicolumn{3}{|c|}{ Bad Gleichenberg } & \multicolumn{3}{|c|}{ Kremsmünster } & \multicolumn{3}{|c|}{ Poysdorf } \\
\hline \multicolumn{10}{|c|}{ RCP 8.5, EC-EARTH_CLM } \\
\hline maize_no irr & 1.2 & 2.3 & 2.3 & -0.1 & 0.3 & 0.8 & 1.7 & 4.8 & 5.6 \\
\hline maize_irr & 0.6 & 2.4 & 1.4 & -0.8 & -0.4 & 0.1 & 0.2 & 1.4 & 1.8 \\
\hline spring barley & -0.3 & 0.2 & 0.7 & -0.4 & 0.1 & 0.4 & 0.3 & 1.6 & 0.9 \\
\hline winter wheat & 0.9 & 0.1 & -0.1 & 0.9 & 1.0 & 1.0 & 0.8 & 1.7 & 2.0 \\
\hline \multicolumn{10}{|c|}{ RCP 8.5, EC-EARTH_RACMO } \\
\hline maize_no irr & 1.2 & 2.1 & 1.5 & -1.0 & -0.8 & -0.7 & -0.9 & 3.2 & 2.8 \\
\hline maize_irr & 1.1 & 1.8 & 1.2 & -1.7 & -1.3 & -1.0 & -0.3 & 2.5 & 2.4 \\
\hline spring barley & -0.1 & 0.8 & 0.4 & 0.4 & 0.5 & 0.3 & 0.4 & 1.1 & 1.6 \\
\hline winter wheat & -0.1 & -0.1 & 0.2 & -1.9 & -2.4 & -1.2 & 0.7 & 0.6 & 0.5 \\
\hline \multicolumn{10}{|c|}{ RCP 8.5, IPSL_WRF } \\
\hline maize_no irr & 1.7 & 3.0 & 2.4 & -0.6 & -0.5 & 0.1 & 2.1 & 4.5 & 4.4 \\
\hline maize_irr & 1.7 & 3.0 & 2.4 & -0.6 & -0.5 & 0.1 & 0.1 & -0.1 & 0.5 \\
\hline spring barley & -0.2 & 1.2 & 0.0 & -1.2 & -1.3 & -0.7 & 0.4 & 1.7 & 1.6 \\
\hline winter wheat & 0.6 & 0.7 & 1.0 & -1.0 & -0.8 & -0.4 & 0.4 & 1.8 & 1.5 \\
\hline \multicolumn{10}{|c|}{ RCP 8.5, HadGEM_CLM } \\
\hline maize_no irr & 0.1 & -2.0 & -0.5 & 2.2 & 2.6 & 2.9 & -2.3 & 2.4 & 1.7 \\
\hline maize_irr & 1.6 & 2.6 & 2.2 & -0.1 & 0.4 & 0.8 & -0.4 & 1.4 & 0.0 \\
\hline spring barley & -0.5 & 0.6 & 0.5 & 0.3 & 1.5 & 0.8 & 1.8 & 3.1 & 3.6 \\
\hline winter wheat & 0.9 & 0.5 & 0.6 & -0.6 & -0.5 & 0.5 & 1.7 & 2.3 & 2.0 \\
\hline \multicolumn{10}{|c|}{ RCP 8.5, HadGEM_RCA } \\
\hline maize_no irr & 1.3 & 3.1 & 3.0 & 0.7 & 0.7 & 0.9 & 2.8 & 7.5 & 6.0 \\
\hline maize_irr & 1.2 & 3.2 & 2.7 & 0.2 & 0.4 & 0.7 & -0.9 & 1.0 & -0.3 \\
\hline spring barley & 1.0 & 0.7 & 0.3 & 0.7 & 0.7 & 1.6 & 0.6 & 0.8 & 1.1 \\
\hline winter wheat & 0.6 & 1.0 & 1.1 & -0.9 & -0.8 & -0.5 & -0.3 & 1.0 & 0.5 \\
\hline
\end{tabular}

Table 9. Yield differences (\%) for maize (rainfed = no irr, optimally irrigated = irr), winter wheat and spring barley (rainfed) grown on the sandy soil class $1 ; 1 \mathrm{~km}$ input data vs. 5, 11, and $21 \mathrm{~km}$ aggregated datasets for five ÖKS15 projections RCP 8.5 (EC-Earth_CLM, EC-Earth_RACMO, IPSL_WRF, IPSL_RCA, and HadGEM_RCA) for Bad Gleichenberg, Kremsmünster, and Poysdorf for the 2071-2100 period. Differences in percentages compared with the results with a $1 \mathrm{~km}$ resolution.

\begin{tabular}{|c|c|c|c|c|c|c|c|c|c|}
\hline \multicolumn{10}{|c|}{ RCP 8.5 2071-2100 } \\
\hline & 5 & 11 & 21 & 5 & 11 & 21 & 5 & 11 & 21 \\
\hline & km & km & km & km & km & km & km & km & km \\
\hline & \multicolumn{3}{|c|}{ Bad Gleichenberg } & \multicolumn{3}{|c|}{ Kremsmünster } & \multicolumn{3}{|c|}{ Poysdorf } \\
\hline \multicolumn{10}{|c|}{ RCP 8.5, EC-EARTH_CLM } \\
\hline maize_no irr & 0.4 & 0.4 & 0.8 & -0.9 & -0.8 & -1.1 & 0.3 & 0.9 & 0.4 \\
\hline maize_irr & 0.2 & 0.6 & 1.1 & -1.1 & -1.0 & -1.3 & -0.2 & 0.2 & -0.4 \\
\hline spring barley & -1.3 & -0.5 & -1.1 & 0.0 & 0.0 & 0.5 & 0.6 & 1.5 & 1.1 \\
\hline winter wheat & 0.4 & 1.9 & 1.4 & 0.7 & 0.8 & 1.4 & 0.4 & 1.0 & 1.0 \\
\hline
\end{tabular}


Table 9. Cont.

\begin{tabular}{|c|c|c|c|c|c|c|c|c|c|}
\hline \multicolumn{10}{|c|}{ RCP 8.5 2071-2100 } \\
\hline & 5 & 11 & 21 & 5 & 11 & 21 & 5 & 11 & 21 \\
\hline & km & km & km & km & km & km & km & km & km \\
\hline & \multicolumn{3}{|c|}{ Bad Gleichenberg } & \multicolumn{3}{|c|}{ Kremsmünster } & \multicolumn{3}{|c|}{ Poysdorf } \\
\hline \multicolumn{10}{|c|}{ RCP 8.5, EC-EARTH_RACMO } \\
\hline maize_no irr & 1.7 & 1.8 & 1.8 & 0.5 & -0.3 & 0.5 & 0.5 & 0.5 & 0.7 \\
\hline maize_irr & 1.2 & 2.0 & 1.4 & 0.4 & -0.3 & 0.5 & 0.3 & -0.5 & -0.2 \\
\hline spring barley & -0.8 & 0.9 & 0.0 & -0.4 & 0.0 & 0.5 & 0.3 & 0.8 & 0.9 \\
\hline winter wheat & -0.1 & 0.5 & 0.8 & -1.9 & -1.6 & -0.4 & 0.5 & 1.1 & 0.8 \\
\hline \multicolumn{10}{|c|}{ RCP 8.5, IPSL_WRF } \\
\hline maize_no irr & 0.0 & -0.1 & -1.6 & -2.1 & -1.6 & -1.8 & 0.5 & 1.6 & 2.0 \\
\hline maize_irr & 0.2 & 0.6 & 1.1 & -2.1 & -1.6 & -0.4 & 0.2 & 1.1 & 1.4 \\
\hline spring barley & 0.0 & -0.2 & 0.7 & -0.7 & -0.2 & 0.1 & 0.0 & -0.1 & 0.1 \\
\hline winter wheat & 2.8 & 6.9 & 4.5 & 2.9 & 1.1 & 8.8 & 0.1 & 1.7 & 1.4 \\
\hline \multicolumn{10}{|c|}{ RCP 8.5, HadGEM_CLM } \\
\hline maize_no irr & 0.4 & -0.9 & -0.9 & 3.9 & 4.3 & 3.6 & -0.3 & 0.4 & 1.1 \\
\hline maize_irr & 1.7 & 0.6 & 0.8 & 3.4 & 3.9 & 3.2 & -0.3 & -0.3 & 0.3 \\
\hline spring barley & -1.1 & -0.6 & -1.2 & -0.9 & -0.8 & 0.0 & -0.6 & -0.2 & -0.5 \\
\hline winter wheat & 0.3 & 0.5 & 0.7 & -1.6 & -1.5 & -0.6 & 1.3 & 1.0 & 1.4 \\
\hline \multicolumn{10}{|c|}{ RCP 8.5, HadGEM_RCA } \\
\hline maize_no irr & 1.3 & 1.3 & 1.2 & 0.7 & 1.0 & 0.9 & -1.5 & -0.7 & -0.8 \\
\hline maize_irr & 1.2 & 1.3 & 1.3 & 0.7 & 1.1 & 0.7 & -1.0 & -0.5 & -0.5 \\
\hline spring barley & 0.5 & 1.1 & 1.7 & -2.6 & -2.3 & -2.1 & -1.9 & -0.4 & -0.6 \\
\hline winter wheat & 0.4 & 1.8 & 1.4 & -2.2 & -2.0 & -1.0 & 0.4 & 1.5 & 1.0 \\
\hline
\end{tabular}

\section{Discussion}

Precipitation pattern changes, temperature increases and atmospheric $\mathrm{CO}_{2}$ concentration have a complex impact on crop growth and development, affecting crop yields $[15,16,58,59]$ and product quality [60], depending on the regional environmental conditions [61-64]. The sensitive phases of crops may shift, and critical heat, drought, late frost, or heavy precipitation conditions appear [39,65-67]. Due to changes in climate variability, climate extremes can occur more frequently, which increases the likelihood of unfavorable crop growing conditions $[14,68]$. Mechanistic explanatory crop models are frequently applied to assess soil-crop-weather interactions within an agronomic system and under different environmental conditions, in order to adapt, for example, management practices (e.g., irrigation and fertilization) to the changing climate [14,69-71]. However, the simulation tools, as well as databases and scenarios for simulations contain uncertainties. In our study, we analyzed the Austrian ÖKS15 climate projections, which were initiated to create a common basis for climate impact studies and risk analyses in Austria [40].

First, we attributed the sensitivity of the crop model results to uncertainties in the weather input data based on the ensemble of ÖKS15 projections for the 1981-2010 period compared with weather station data. Even though the weather data of the projections were bias-corrected, we identified differences in the crop yield simulation results. For example, the HadGEM_CLM projection, which contains a very low level of precipitation in summer, showed yield distortions, especially for rainfed grain maize, and was an outlier within the set of ÖKS15 scenarios. Looking at the three sites with different climates, it can be seen that Poysdorf, the location with the lowest mean annual precipitation, showed the largest variation, and this was particularly pronounced for soil 1 , which has the lowest soil water storage capacity. In general, for that soil type, this was particularly evident with rainfed maize, which was used as a reference summer crop. Another factor is that the climate in Austria is essentially determined by complex orography and related weather patterns. If climate models do not represent local weather conditions accurately in terms 
of their frequency and duration, the simulated impacts on crops will deviate from reality. Indeed, bias correction of climate scenarios does not correct for such weather patterns [71]. However, an evaluation showed that most of the ÖKS15 projections at least represent the frequency of weather patterns realistically [41].

Crops can respond to rising atmospheric $\mathrm{CO}_{2}$-levels by increasing their photosynthetic activity (known as the " $\mathrm{CO}_{2}$-fertilization effect"). However, depending on the crop type or cultivar, genetics, and environmental conditions, the response can vary widely, and longterm adaptations or feedback are uncertain [72-79]. In our study, we only simulated a predefined maximum response case in relation to the applied emission scenarios. The response for the C4-crop maize was lower (a maximum of $+4.2 \%$ assimilation rate vs. doubling of the $\mathrm{CO}_{2}$-concentration from current levels) than for $\mathrm{C} 3$-crops (e.g., cereals, with a maximum of $27 \%$ positive response for doubled current levels) [80]. The results show, according to this parameterization, that the positive yield effect was stronger under RCP 8.5 due to the assumption of a higher $\mathrm{CO}_{2}$ concentration. Spring barley and winter wheat, as C3-crops, emerged as winners in most of the projections, confirming the results of various other simulation-based climate change crop impact studies conducted in Austria [54,55,81-83]. By contrast, without any cultivar change, irrigated and rainfed maize will face yield losses by the end of the century, but these were predicted to be lower under RCP 4.5, due to less warming (which reduces the length of the growing period). However, these general simulated differentiations between emission scenarios could disappear due to weather factors, as was the case with rainfed maize at the dry site, Poysdorf, where the precipitation pattern became the dominating yield factor. Due to the limitation of the model settings applied and their potential uncertainties regarding crop-environment interactions within the crop model, the results of the simulations therefore only show a range of possible impacts that may occur at the end of the century.

The uncertainty in crop model applications is also linked to the quality and representativeness of the input data for specific application sites. For example, aggregated weather and/or soil input datasets have less spatial variability and thus there is a potential for bias with respect to simulated stress events. This can, for example, be more pronounced in regions with highly heterogeneous weather conditions and orography. In this regard, in our study, the sensitivity of simulated yields on weather input data with different spatial resolutions, namely, aggregated weather data with resolutions of $1 \mathrm{~km}$ vs. 5, 11, and $21 \mathrm{~km}$, in three orographic different study regions, was analyzed in more detail. As with the modelling of the bias-corrected input data with the measured weather station data, the results show that even small deviations (caused by aggregation) can have an impact on the simulated crop yield. For the selected projections, the RCP 8.5 model showed smaller deviations between the aggregated input datasets than the RCP 4.5 simulations. This was due, on the one hand, to the much higher temperatures present in the RCP 8.5 emission scenario, making the spatial aggregation less important under the respective environmental conditions. On the other hand, the more humid conditions found in RCP 8.5, reduce the influence of the spatial variation of precipitation on soil type-specific drought stress risk. In general, Bad Gleichenberg was found to have the largest differences in the aggregated input data, which can be attributed to its more complex topography and greater differences in the local climate compared to the other sites. This was particularly reflected in the maize simulations due to the higher response of this crop to temperature limitations than that of cereals under local climate conditions. For example, the aggregated weather data in RCP 4.5 gave higher yields with EC-EARTH_RCA (1981-2010), IPSL_RCA, and HadGEM_CLM (2071-2100). In contrast, at the Kremsmünster site, the coolest and wettest location, the aggregated input datasets had in most cases only a small impact on simulated grain yields. Poysdorf, on the other hand, displayed clear deviations between the aggregated datasets. Although it is in a flat region, it is the driest place, and spatial variation in precipitation was associated with large yield differences. 
Based on these results, recommendations for the application of impact models under highly variable regional conditions (climate, orography, and soil characteristics) such as are found in Austria, are derived, as follows:

- Solid calibration and validation of crop growth models should include the application of measured data (weather, soil, crop) over a longer period (ideally $>10$ years) and across multiple sites covering the main ecosystem dynamics in the study area of interest;

- The use of ensembles of climate change scenarios to cover a probable range of "reality" that can be expected in the future;

- Consideration of adverse weather conditions (heat, drought, very high rainfall) during the growing season in model applications to better understand critical phases and their impacts on crops;

- Application of an ensemble of calibrated and validated impact models to capture a range of uncertainties arising from the structures of different models. It may help to tie the response functions of the models to weather parameters, especially regarding critical thresholds, such as heat and drought stress;

- Simulation of different expected future crop management scenarios, such as changes in tillage, adaption of new cultivars, and the modification of irrigation and fertilization strategies, in order to incorporate their effects into the results;

- If regional studies of climate change impacts on crop production are already available, they can be refined within the framework of updated regional climate scenarios. Of key interest is whether there will be a shift in weather events, such as increases in the frequency of heat waves, the occurrence of frost, and an increase or decrease in precipitation;

- With more complex terrain topography, greater spatial variability can be expected in simulation results, leading to large spatial shifts in crop growth conditions within a small region. Here, it is necessary to use high-resolution climate scenarios and weather input data in order to, e.g., develop adaptation recommendations for local farmers.

\section{Conclusions}

In this study, we analyzed the quality, reliability, and uncertainty of Austrian climate projections (ÖKS15) and their impacts on the results of a crop model. We included different spatial aggregation levels for the related gridded weather input data for three different agricultural regions in Austria. Gridded weather and climate data provide a common basis for climate impact studies and risk analyses, where complex orography (the Eastern Alpine region, in our case) causes high spatial climate variations and potential biases in climate projections if the orography is not represented with sufficient detail. We showed which projections caused the largest deviations with respect to the regional current and future climate conditions for different soils and simulated crops. Based on the results, the main recommendations include the need for better local representativeness for crop model input data and the consideration of model-based uncertainties for the development of appropriate site-specific adaptation options for agriculture in the future.

Author Contributions: The work was performed through a collaboration by all co-authors. S.T. and J.E. conceived the research. H.F. and G.K. provided the ÖKS 15 scenarios, M.T. contributed crop model inputs. S.T. performed the statistical analysis and prepared the manuscript. All authors contributed to the critical analysis of the obtained results and read and commented on the manuscript throughout the writing process. All authors have read and agreed to the published version of the manuscript.

Funding: This research received no external funding. 
Acknowledgments: The research work described in the paper was carried out with support from several projects. The database, simulations, and analysis were supported by the STARC-Impact, COMBIRISK and AGROFORECAST projects of the Austrian Climate Research Program (ACRP), as well as by SustES-Adaptation strategies for sustainable ecosystem services and food security under adverse environmental conditions (CZ.02.1.01/0.0/0.0/16_019/0000797).

Conflicts of Interest: The authors declare no conflict of interest.

\section{Appendix A}

Table A1. Annual differences in the maximum (Tmax) and minimum temperatures (Tmin) in K and the precipitation (Rain) as a \% in Poysdorf, Bad Gleichenberg, and Kremsmünster for the 13 ÖKS15 projections (RCP 4.5 and RCP 8.5): 2071-2100 vs. 1981-2010.

\begin{tabular}{|c|c|c|c|c|c|c|}
\hline & \multicolumn{3}{|c|}{ RCP 4.5} & \multicolumn{3}{|c|}{ RCP 8.5} \\
\hline & Tmax & Tmin & Rain & Tmax & Tmin & Rain \\
\hline ÖKS15 Projection & (K) & (K) & $(\%)$ & (K) & (K) & $(\%)$ \\
\hline \multicolumn{7}{|c|}{ Poysdorf } \\
\hline CNRM_CLM & 1.4 & 1.7 & 11.3 & 2.8 & 3.1 & 8 \\
\hline CNRM_ALADIN & 2.1 & 2.4 & 14.5 & 3.6 & 4.2 & 20.9 \\
\hline CNRM_RCA & 1.7 & 1.8 & 8.4 & 3.6 & 3.6 & 7.7 \\
\hline EC-EARTTH_CLM & 1.5 & 1.8 & 9.6 & 3.1 & 3.2 & 11.2 \\
\hline EC-EARTH_RCA & 2 & 2 & 10.9 & 3.9 & 3.7 & 14.9 \\
\hline EC-EARTH_RACMO & 2.1 & 2.3 & 5.6 & 3.6 & 3.8 & 8.5 \\
\hline EC-EARTH_HIRHAM & 1.4 & 1.6 & 16.4 & 3.1 & 3.2 & 14 \\
\hline IPSL_WRF & 1.9 & 2.2 & 14.1 & 3.1 & 3.8 & 33.2 \\
\hline IPSL_RCA & 2.2 & 2.1 & 12.7 & 4 & 3.8 & 17.6 \\
\hline HadGEME_CLM & 2.8 & 2.7 & 4.3 & 5 & 4.9 & 10.9 \\
\hline HadGEM_RCA & 2.3 & 2.5 & 15.2 & 4.6 & 4.5 & 5.6 \\
\hline MPI_CLM & 1.3 & 1.3 & 4.9 & 2.9 & 3 & 6.4 \\
\hline MPI_RCA & 1.4 & 1.4 & 7.4 & 3.4 & 3.4 & 15.7 \\
\hline \multicolumn{7}{|c|}{ Bad Gleichenberg } \\
\hline CNRM_CLM & 1.6 & 1.7 & 9.2 & 3 & 3.1 & 2.1 \\
\hline CNRM_ALADIN & 2.1 & 2.4 & 9.7 & 3.6 & 4.1 & 12.1 \\
\hline CNRM_RCA & 2 & 1.9 & 4.8 & 3.9 & 3.6 & 1.4 \\
\hline EC-EARTH_CLM & 1.7 & 1.8 & 4.5 & 3.3 & 3.3 & 6.7 \\
\hline EC-EARTH_RCA & 2.2 & 2 & 3.6 & 4.2 & 3.9 & 5.6 \\
\hline EC-EARTH_RACMO & 2 & 2.3 & 8.8 & 3.7 & 4 & 3.3 \\
\hline EC-EARTH_HIRHAM & 1.4 & 1.5 & 15.8 & 3 & 3.2 & 14.4 \\
\hline IPSL_WRF & 1.8 & 2.1 & 17.9 & 3.2 & 3.7 & 36.8 \\
\hline IPSL_RCA & 2.5 & 2.1 & 4.2 & 4.3 & 4.1 & 18.4 \\
\hline HadGEM_CLM & 2.8 & 2.8 & 3.6 & 5.1 & 5 & -6.3 \\
\hline HadGEM_RCA & 2.5 & 2.4 & 11 & 4.7 & 4.5 & 8.9 \\
\hline MPI_CLM & 1.5 & 1.4 & -2.4 & 3.2 & 3.1 & 2.3 \\
\hline MPI_RCA & 1.7 & 1.6 & 6.1 & 3.8 & 3.6 & 10.5 \\
\hline \multicolumn{7}{|c|}{ Kremsmünster } \\
\hline CNRM_CLM & 1.5 & 1.6 & 7.8 & 2.9 & 3.1 & 9.8 \\
\hline CNRM_ALADIN & 1.8 & 2.3 & 16.2 & 3.3 & 4.3 & 27 \\
\hline CNRM_RCA & 1.7 & 1.9 & 10.3 & 3.4 & 3.6 & 14.1 \\
\hline EC-EARTH_CLM & 1.6 & 1.8 & 10.6 & 3.2 & 3.3 & 11.3 \\
\hline EC-EARTH_RCA & 2 & 1.9 & 9.6 & 3.9 & 3.6 & 10.6 \\
\hline EC-EARTH_RACMO & 2.2 & 2.4 & 4.3 & 3.7 & 4 & 6.5 \\
\hline EC-EARTH_HIRHAM & 1.4 & 1.6 & 6.2 & 3.1 & 3.2 & 7 \\
\hline IPSL_WRF & 1.9 & 2.1 & 11.5 & 3.1 & 3.6 & 27.5 \\
\hline IPSL_RCA & 2.4 & 2 & 2.5 & 4.3 & 3.9 & 2.7 \\
\hline HadGEM_CLM & 3.1 & 2.8 & -2 & 5.4 & 5 & -3.7 \\
\hline
\end{tabular}


Table A1. Cont.

\begin{tabular}{lcccccc}
\hline & \multicolumn{3}{c}{ RCP 4.5 } & \multicolumn{3}{c}{ RCP 8.5 } \\
\hline & Tmax & Tmin & Rain & Tmax & Tmin & Rain \\
\hline ÖKS15 Projection & $\mathbf{( K )}$ & $\mathbf{( K )}$ & $\mathbf{( \% )}$ & $\mathbf{( K )}$ & $\mathbf{( K )}$ & $\mathbf{( \% )}$ \\
\hline HadGEM_RCA & 2.4 & 2.5 & 11.1 & 4.7 & 4.4 & 6.3 \\
MPI_CLM & 1.4 & 1.4 & 2.4 & 2.9 & 3 & 7.9 \\
MPI_RCA & 1.5 & 1.5 & 7.5 & 3.6 & 3.3 & 9.5 \\
\hline
\end{tabular}

\section{Appendix B}

Table A2. Mean, Median, Maximum (Max), and Minimum (Min) values, as well as 90th and 10th percentiles for all ÖKS15 yield differences (in \%) (projections vs. ZAMG simulations) for three different soil classes: (a) RCP 4.5; and (b) RCP 8.5; baseline in Poysdorf, Bad Gleichenberg, and Kremsmünster (irr = irrigated; no irr = rainfed).

\begin{tabular}{|c|c|c|c|c|c|c|c|c|c|c|c|c|c|}
\hline & & \multicolumn{3}{|c|}{ Maize Irr } & \multicolumn{3}{|c|}{ Maize No Irr } & \multicolumn{3}{|c|}{ Spring Barley } & \multicolumn{3}{|c|}{ Winter Wheat } \\
\hline & (a) RCP 4.5 & Soil 1 & Soil 2 & Soil 3 & Soil 1 & Soil 2 & Soil 3 & Soil 1 & Soil 2 & Soil 3 & Soil 1 & Soil 2 & Soil 3 \\
\hline \multirow{6}{*}{ 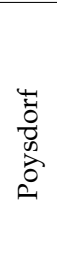 } & Mean & 2.7 & 3.0 & 3.1 & 0.2 & 2.5 & -0.8 & -0.2 & -3.3 & -3.1 & -2.2 & -3.3 & -4.8 \\
\hline & Median & 2.7 & 2.7 & 2.8 & 2.7 & 3.7 & 0.3 & 0.3 & -3.8 & -3.6 & -1.9 & -4.0 & -5.7 \\
\hline & Max & 6.0 & 6.5 & 7.1 & 10.2 & 14.0 & 9.8 & 3.7 & 2.3 & 2.3 & 3.7 & 1.4 & 0.2 \\
\hline & Min & 0.4 & 0.8 & 0.2 & -14.9 & -11.4 & -13.5 & -5.0 & -10.0 & -9.7 & -7.1 & -7.9 & -9.7 \\
\hline & $\begin{array}{l}\text { Percentile } \\
90 \%\end{array}$ & 5.5 & 5.9 & 6.4 & 7.4 & 7.0 & 2.9 & 2.2 & 0.8 & 0.4 & 0.8 & 0.5 & -1.0 \\
\hline & $\begin{array}{l}\text { Percentile } \\
10 \%\end{array}$ & 0.7 & 1.0 & 0.7 & -12.7 & -8.1 & -10.5 & -3.3 & -6.5 & -6.7 & -5.9 & -7.2 & -7.4 \\
\hline \multirow{6}{*}{ 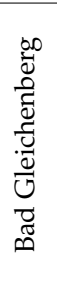 } & Mean & 0.6 & 1.1 & 0.6 & -4.0 & 0.3 & 0.5 & -1.4 & -0.1 & 0.1 & -3.8 & -2.1 & -2.2 \\
\hline & Median & 0.2 & 0.9 & 0.3 & -3.3 & 0.6 & 0.2 & -1.6 & 0.0 & -0.2 & -3.7 & -2.3 & -2.3 \\
\hline & $\operatorname{Max}$ & 4.4 & 5.0 & 4.3 & 4.0 & 5.2 & 4.4 & 2.0 & 2.5 & 2.6 & -1.6 & 0.1 & -1.3 \\
\hline & Min & -2.1 & -1.7 & -1.7 & -19.3 & -3.8 & -1.7 & -4.9 & -3.2 & -3.3 & -6.9 & -3.5 & -3.7 \\
\hline & $\begin{array}{l}\text { Percentile } \\
90 \%\end{array}$ & 3.3 & 3.5 & 2.8 & 1.1 & 3.1 & 2.8 & 0.4 & 1.9 & 2.2 & -2.0 & -1.3 & -1.6 \\
\hline & $\begin{array}{l}\text { Percentile } \\
10 \%\end{array}$ & -1.2 & -0.9 & -1.1 & -7.6 & -2.1 & -1.1 & -3.4 & -1.9 & -0.9 & -6.5 & -3.2 & -2.8 \\
\hline \multirow{8}{*}{ 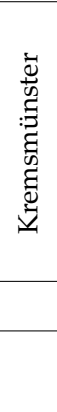 } & Mean & 1.3 & 2.6 & 2.8 & 0.8 & 4.1 & 4.4 & -1.2 & -0.6 & 0.3 & -1.3 & -0.9 & -0.9 \\
\hline & Median & 1.6 & 1.9 & 2.6 & 0.8 & 3.6 & 4.2 & -0.4 & 0.3 & 0.7 & -1.3 & -1.0 & -1.0 \\
\hline & Max & 4.2 & 5.3 & 5.5 & 7.2 & 7.1 & 7.2 & 1.6 & 0.9 & 1.9 & 1.4 & 0.5 & 0.6 \\
\hline & Min & -3.7 & -0.4 & 0.0 & -5.9 & 1.4 & 1.5 & -5.8 & -4.4 & -2.9 & -4.9 & -3.0 & -2.2 \\
\hline & $\begin{array}{l}\text { Percentile } \\
90 \%\end{array}$ & 4.0 & 5.0 & 5.1 & 5.1 & 6.8 & 6.8 & 0.6 & 0.8 & 1.6 & 0.3 & 0.3 & 0.1 \\
\hline & $\begin{array}{l}\text { Percentile } \\
10 \%\end{array}$ & -0.8 & 0.9 & 0.3 & -3.0 & 1.6 & 1.9 & -3.8 & -2.6 & -1.4 & -3.3 & -2.1 & -2.1 \\
\hline & & \multicolumn{3}{|c|}{ Maize Irr } & \multicolumn{3}{|c|}{ Maize No Irr } & \multicolumn{3}{|c|}{ Spring Barley } & \multicolumn{3}{|c|}{ Winter Wheat } \\
\hline & $\begin{array}{l}\text { (b) } \\
\text { RCP } 8.5\end{array}$ & Soil 1 & Soil 2 & Soil 3 & Soil 1 & Soil 2 & Soil 3 & Soil 1 & Soil 2 & Soil 3 & Soil 1 & Soil 2 & Soil 3 \\
\hline \multirow{6}{*}{ 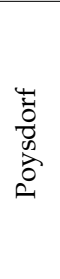 } & Mean & 2.6 & 2.9 & 3.1 & 0.2 & 4.5 & 0.8 & 0.1 & -3.6 & -3.4 & -0.2 & -0.2 & -2.3 \\
\hline & Median & 2.4 & 2.7 & 3.0 & 3.5 & 5.0 & 1.3 & 0.2 & -3.2 & -3.8 & -1.0 & -0.9 & -2.9 \\
\hline & $\operatorname{Max}$ & 7.0 & 7.5 & 7.7 & 6.1 & 15.7 & 11.4 & 5.9 & 0.1 & 0.2 & 5.5 & 6.5 & 3.3 \\
\hline & Min & -0.3 & 0.1 & -0.9 & -15.7 & -9.4 & -10.7 & -4.5 & -8.9 & -8.8 & -2.5 & -5.9 & -7.4 \\
\hline & $\begin{array}{l}\text { Percentile } \\
90 \%\end{array}$ & 4.9 & 5.3 & 6.3 & 5.7 & 12.0 & 5.7 & 2.3 & -0.3 & -0.6 & 2.3 & 3.4 & 0.2 \\
\hline & $\begin{array}{l}\text { Percentile } \\
10 \%\end{array}$ & 0.4 & 0.6 & 1.1 & -11.3 & -3.8 & -5.2 & -2.9 & -7.0 & -7.1 & -2.4 & -2.8 & -4.5 \\
\hline \multirow{6}{*}{ 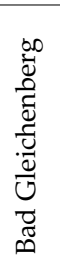 } & Mean & 0.1 & 0.7 & 0.2 & -4.7 & 0.0 & 0.2 & -0.4 & -0.1 & 0.0 & -3.4 & -1.8 & -2.2 \\
\hline & Median & 0.3 & 1.0 & 0.1 & -3.8 & 0.1 & -0.1 & -0.5 & 0.0 & -0.4 & -3.5 & -2.0 & -2.4 \\
\hline & Max & 4.6 & 5.2 & 4.7 & 4.2 & 5.4 & 4.7 & 0.7 & 2.1 & 1.8 & -0.8 & 2.0 & -1.0 \\
\hline & Min & -2.1 & -2.1 & -2.2 & -17.0 & -4.4 & -2.2 & -1.8 & -1.7 & -2.0 & -7.3 & -3.7 & -3.9 \\
\hline & $\begin{array}{l}\text { Percentile } \\
90 \%\end{array}$ & 1.5 & 1.6 & 1.6 & -1.1 & 1.4 & 1.6 & 0.6 & 1.3 & 1.6 & -1.6 & -0.9 & -1.1 \\
\hline & $\begin{array}{l}\text { Percentile } \\
10 \%\end{array}$ & -1.7 & -1.3 & -1.8 & -7.8 & -2.3 & -1.8 & -1.3 & -1.5 & -1.2 & -5.0 & -3.2 & -3.1 \\
\hline
\end{tabular}


Table A2. Cont.

\begin{tabular}{|c|c|c|c|c|c|c|c|c|c|c|c|c|c|}
\hline & \multirow[b]{2}{*}{$\begin{array}{l}\text { (b) } \\
\text { RCP } 4.5\end{array}$} & \multicolumn{3}{|c|}{ Maize Irr } & \multicolumn{3}{|c|}{ Maize No Irr } & \multicolumn{3}{|c|}{ Spring Barley } & \multicolumn{3}{|c|}{ Winter Wheat } \\
\hline & & Soil 1 & Soil 2 & Soil 3 & Soil 1 & Soil 2 & Soil 3 & Soil 1 & Soil 2 & Soil 3 & Soil 1 & Soil 2 & Soil 3 \\
\hline \multirow{6}{*}{ 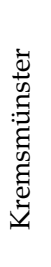 } & Mean & 0.7 & 2.2 & 2.2 & -0.2 & 2.9 & 3.5 & -1.5 & -0.8 & 0.1 & -1.2 & -1.2 & -1.1 \\
\hline & Median & 0.5 & 2.3 & 1.9 & 0.5 & 2.8 & 3.2 & -1.3 & 0.0 & -0.2 & -1.0 & -1.2 & -1.2 \\
\hline & Max & 4.0 & 5.3 & 5.6 & 5.4 & 6.5 & 6.9 & 0.7 & 1.4 & 2.9 & 1.8 & 1.5 & 2.0 \\
\hline & Min & -1.4 & -0.9 & -1.1 & -8.0 & 0.1 & 0.2 & -5.1 & -3.6 & -2.6 & -3.8 & -4.1 & -3.8 \\
\hline & $\begin{array}{l}\text { Percentile } \\
90 \%\end{array}$ & 2.7 & 4.6 & 5.3 & 3.5 & 5.6 & 6.6 & 0.5 & 1.3 & 2.3 & 0.6 & 0.7 & 0.4 \\
\hline & $\begin{array}{l}\text { Percentile } \\
10 \%\end{array}$ & -1.2 & -0.4 & -0.7 & -4.4 & 0.4 & 0.5 & -4.1 & -3.0 & -1.7 & -3.6 & -2.8 & -2.9 \\
\hline
\end{tabular}

\section{Appendix C}

Table A3. Mean, Median, Maximum (Max), and Minimum (Min) values as well as 90th and 10th percentiles across all ÖKS15 yield deviations (in \%) (2071-2100 vs. 1981-2010) for three different soil classes and for RCP 4.5 and RCP 8.5 in Poysdorf, Bad Gleichenberg, and Kremsmünster (irr = irrigated; no irr = rainfed).

\begin{tabular}{|c|c|c|c|c|c|c|c|c|c|c|c|c|}
\hline \multicolumn{13}{|c|}{ Poysdorf } \\
\hline \multirow{2}{*}{$\begin{array}{l}\text { RCP } 4.5 \\
\text { Yield Deviations (\%) }\end{array}$} & \multicolumn{3}{|c|}{ Grain Maize (Irr) } & \multicolumn{3}{|c|}{ Grain Maize (No Irr) } & \multicolumn{3}{|c|}{ Spring Barley } & \multicolumn{3}{|c|}{ Winter Wheat } \\
\hline & Soil 1 & Soil 2 & Soil 3 & Soil 1 & Soil 2 & Soil 3 & Soil 1 & Soil 2 & Soil 3 & Soil 1 & Soil 2 & Soil 3 \\
\hline Mean & -9.2 & -8.8 & -8.7 & 10.4 & 0.1 & -2.2 & 8.5 & 11.6 & 9.9 & 8.8 & 17.3 & 14.6 \\
\hline Median & -9.1 & -8.8 & -9.8 & 9.5 & -0.4 & -1.8 & 8.5 & 10.4 & 10.0 & 9.2 & 16.7 & 14.8 \\
\hline $\operatorname{Max}$ & -0.5 & 0.0 & 1.4 & 28.1 & 9.6 & 6.1 & 11.6 & 16.7 & 15.9 & 15.7 & 24.7 & 22.2 \\
\hline Min & -13.6 & -13.4 & -14.7 & 0.0 & -8.9 & -12.2 & 6.4 & 6.0 & 5.4 & 0.2 & 10.5 & 7.0 \\
\hline Percentile $90 \%$ & -4.4 & -3.8 & -3.2 & 14.3 & 6.6 & 3.9 & 10.9 & 16.0 & 13.7 & 15.0 & 23.2 & 19.5 \\
\hline Percentile $10 \%$ & -13.0 & -13.2 & -13.0 & 6.1 & -5.7 & -7.7 & 6.7 & 7.5 & 6.2 & 1.6 & 12.4 & 8.4 \\
\hline \multicolumn{13}{|l|}{ RCP 8.5} \\
\hline Mean & -13.0 & -13.1 & -12.8 & 14.4 & -3.6 & -6.8 & 18.6 & 21.8 & 18.4 & 18.0 & 28.7 & 21.2 \\
\hline Median & -14.8 & -14.7 & -15.2 & 14.4 & -1.8 & -7.3 & 18.5 & 23.2 & 18.6 & 17.6 & 28.2 & 20.7 \\
\hline $\operatorname{Max}$ & -4.6 & -3.8 & -4.8 & 22.8 & 3.4 & 1.2 & 22.7 & 28.1 & 24.9 & 26.3 & 41.1 & 29.1 \\
\hline Min & -22.1 & -22.3 & -21.5 & 3.5 & -9.8 & -12.1 & 14.2 & 13.2 & 11.0 & 10.1 & 21.0 & 12.4 \\
\hline Percentile $90 \%$ & -6.1 & -6.1 & -6.1 & 20.9 & 2.5 & -1.7 & 22.5 & 27.5 & 23.4 & 25.1 & 33.9 & 25.2 \\
\hline Percentile $10 \%$ & -17.4 & -17.8 & -16.2 & 7.5 & -8.9 & -11.8 & 14.7 & 15.0 & 11.9 & 11.3 & 23.0 & 16.6 \\
\hline \multicolumn{13}{|c|}{ Bad Gleichenberg } \\
\hline RCP 4.5 & \multicolumn{3}{|c|}{ Grain Maize (Irr) } & \multicolumn{3}{|c|}{ Grain Maize (No Irr) } & \multicolumn{3}{|c|}{ Spring Barley } & \multicolumn{3}{|c|}{ Winter Wheat } \\
\hline & Soil 1 & Soil 2 & Soil 3 & Soil 1 & Soil 2 & Soil 3 & Soil 1 & Soil 2 & Soil 3 & Soil 1 & Soil 2 & Soil 3 \\
\hline Mean & -11.5 & -11.9 & -11.8 & -7.4 & -11.1 & -11.8 & 6.1 & 5.6 & 4.0 & 3.1 & 7.2 & 3.7 \\
\hline Median & -10.4 & -11.8 & -11.3 & -5.7 & -10.7 & -10.6 & 6.1 & 5.5 & 3.9 & 3.2 & 7.0 & 2.8 \\
\hline $\operatorname{Max}$ & -2.2 & -2.7 & -3.5 & 0.7 & -1.9 & -3.4 & 8.1 & 10.1 & 8.3 & 9.4 & 12.3 & 9.3 \\
\hline Min & -21.0 & -22.0 & -21.8 & -14.6 & -18.3 & -21.5 & 3.2 & 1.9 & 0.8 & -1.4 & 2.9 & -0.6 \\
\hline Percentile 90\% & -5.9 & -6.5 & -5.9 & -2.8 & -6.0 & -6.0 & 7.8 & 8.4 & 5.9 & 5.0 & 10.9 & 7.9 \\
\hline Percentile $10 \%$ & -17.3 & -18.8 & -18.1 & -12.8 & -17.9 & -18.1 & 3.8 & 3.2 & 1.5 & 0.4 & 4.4 & 0.7 \\
\hline \multicolumn{13}{|l|}{ RCP 8.5} \\
\hline Mean & -15.4 & -16.3 & -16.5 & -8.4 & -15.6 & -16.5 & 11.9 & 12.2 & 9.3 & 4.3 & 10.1 & 3.1 \\
\hline Median & -15.9 & -16.2 & -16.2 & -10.1 & -15.5 & -16.3 & 11.8 & 12.7 & 9.3 & 6.6 & 11.0 & 4.8 \\
\hline Max & -6.9 & -8.2 & -7.3 & -0.3 & -8.2 & -7.4 & 18.7 & 21.1 & 16.9 & 12.0 & 19.7 & 14.0 \\
\hline Min & -24.9 & -26.5 & -26.6 & -16.0 & -23.1 & -25.9 & 7.9 & 2.9 & 2.0 & -14.0 & -8.4 & -15.3 \\
\hline Percentile 90\% & -9.8 & -10.1 & -10.3 & -2.3 & -9.4 & -10.1 & 15.2 & 19.1 & 14.2 & 11.1 & 19.1 & 9.7 \\
\hline Percentile $10 \%$ & -21.5 & -22.6 & -21.9 & -13.6 & -22.1 & -22.6 & 8.5 & 5.5 & 3.9 & -3.5 & -0.3 & -6.1 \\
\hline \multicolumn{13}{|c|}{ Kremsmünster } \\
\hline \multirow[t]{2}{*}{ RCP 4.5} & \multicolumn{3}{|c|}{ Grain Maize (Irr) } & \multicolumn{3}{|c|}{ Grain Maize (No Irr) } & \multicolumn{3}{|c|}{ Spring Barley } & \multicolumn{3}{|c|}{ Winter Wheat } \\
\hline & Soil 1 & Soil 2 & Soil 3 & Soil 1 & Soil 2 & Soil 3 & Soil 1 & Soil 2 & Soil 3 & Soil 1 & Soil 2 & Soil 3 \\
\hline Mean & -9.6 & -11.1 & -10.5 & -7.4 & -10.9 & -10.5 & 3.0 & 3.0 & 2.4 & 4.4 & 6.0 & 4.0 \\
\hline Median & -10.5 & -12.4 & -13.0 & -8.8 & -12.1 & -13.0 & 2.3 & 2.8 & 2.2 & 4.7 & 4.4 & 3.1 \\
\hline Max & 0.7 & -1.4 & -1.3 & 1.2 & -1.4 & -1.3 & 8.1 & 8.0 & 7.7 & 11.0 & 14.7 & 11.7 \\
\hline Min & -16.2 & -18.1 & -17.1 & -13.9 & -16.8 & -16.8 & -0.8 & -1.0 & -0.7 & -0.4 & 0.0 & -0.8 \\
\hline Percentile 90\% & -0.7 & -4.2 & -3.0 & 0.3 & -3.2 & -2.9 & 6.9 & 6.4 & 5.2 & 7.9 & 10.8 & 9.9 \\
\hline Percentile $10 \%$ & -15.2 & -17.0 & -15.3 & -12.4 & -16.6 & -15.3 & 0.2 & 0.8 & 0.3 & 0.0 & 2.3 & 0.3 \\
\hline
\end{tabular}


Table A3. Cont.

\begin{tabular}{|c|c|c|c|c|c|c|c|c|c|c|c|c|}
\hline \multicolumn{13}{|c|}{ Kremsmünster } \\
\hline \multirow[t]{2}{*}{ RCP 4.5} & \multicolumn{3}{|c|}{ Grain Maize (Irr) } & \multicolumn{3}{|c|}{ Grain Maize (No Irr) } & \multicolumn{3}{|c|}{ Spring Barley } & \multicolumn{3}{|c|}{ Winter Wheat } \\
\hline & Soil 1 & Soil 2 & Soil 3 & Soil 1 & Soil 2 & Soil 3 & Soil 1 & Soil 2 & Soil 3 & Soil 1 & Soil 2 & Soil 3 \\
\hline \multicolumn{13}{|l|}{ RCP 8.5} \\
\hline Mean & -15.3 & -17.3 & -16.8 & -12.0 & -17.0 & -16.7 & 10.3 & 9.9 & 8.7 & 6.0 & 8.3 & 5.0 \\
\hline Median & -15.0 & -17.0 & -16.5 & -14.3 & -17.0 & -16.4 & 9.1 & 9.9 & 9.2 & 6.5 & 9.1 & 5.2 \\
\hline Max & -7.4 & -10.6 & -9.7 & -3.0 & -10.6 & -9.6 & 15.3 & 13.4 & 11.5 & 14.9 & 14.0 & 11.7 \\
\hline Min & -24.2 & -25.6 & -24.9 & -19.1 & -24.3 & -24.7 & 5.9 & 5.3 & 5.3 & -6.4 & -0.6 & -4.0 \\
\hline Percentile $90 \%$ & -8.9 & -10.9 & -10.5 & -4.6 & -10.9 & -10.5 & 14.3 & 12.9 & 10.6 & 12.1 & 12.7 & 9.1 \\
\hline Percentile $10 \%$ & -20.9 & -21.9 & -22.6 & -16.9 & -21.8 & -22.6 & 7.4 & 6.8 & 5.9 & 0.3 & 3.0 & 0.3 \\
\hline
\end{tabular}

\section{Appendix D}

Table A4. Mean, Median, Maximum (Max), and Minimum (Min) values as well as 90th and 10th percentiles across all ÖKS15 yield deviations (in \%) (2071-2100 RCP 8.5 vs. RCP 4.5) for three different soil classes in Poysdorf, Bad Gleichenberg, and Kremsmünster (irr = irrigated; no irr = rainfed).

\begin{tabular}{|c|c|c|c|c|c|c|c|c|c|c|c|c|c|}
\hline & \multirow[b]{2}{*}{ Yield Deviations (\%) } & \multicolumn{3}{|c|}{ Maize Irr } & \multicolumn{3}{|c|}{ Maize No Irr } & \multicolumn{3}{|c|}{ Spring Barley } & \multicolumn{3}{|c|}{ Winter Wheat } \\
\hline & & Soil 1 & Soil 2 & Soil 3 & Soil 1 & Soil 2 & Soil 3 & Soil 1 & Soil 2 & Soil 3 & Soil 1 & Soil 2 & Soil 3 \\
\hline \multirow{6}{*}{ 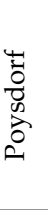 } & Mean & -4.3 & -4.7 & -4.5 & 3.8 & -3.1 & -4.4 & 9.7 & 8.9 & 7.3 & 8.9 & 10.2 & 6.0 \\
\hline & Median & -4.3 & -5.1 & -4.9 & 4.2 & -3.8 & -4.8 & 10.6 & 9.2 & 7.0 & 9.3 & 8.8 & 5.6 \\
\hline & Max & 3.0 & 2.9 & 4.2 & 7.9 & 3.1 & 3.8 & 15.1 & 15.0 & 14.7 & 17.0 & 17.1 & 11.7 \\
\hline & Min & -9.7 & -10.5 & -9.6 & -4.3 & -8.8 & -9.0 & 2.9 & 1.1 & 0.6 & 0.4 & 5.3 & -0.1 \\
\hline & Percentile $90 \%$ & -0.8 & -1.2 & -0.4 & 7.4 & 2.0 & 0.7 & 12.5 & 12.8 & 10.0 & 14.7 & 14.6 & 9.8 \\
\hline & Percentile $10 \%$ & -8.8 & -8.8 & -8.6 & -0.2 & -8.0 & -8.4 & 5.7 & 2.6 & 3.4 & 4.4 & 6.2 & 3.3 \\
\hline \multirow{6}{*}{ 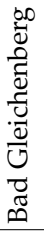 } & Mean & -4.8 & -5.3 & -5.6 & -2.2 & -5.3 & -5.4 & 6.5 & 6.2 & 5.1 & 1.5 & 3.1 & -0.6 \\
\hline & Median & -5.0 & -6.1 & -7.4 & -2.1 & -5.8 & -5.8 & 7.2 & 5.7 & 6.1 & 2.9 & 5.3 & 0.7 \\
\hline & Max & 3.8 & 2.9 & 3.5 & 5.3 & 2.9 & 3.5 & 11.7 & 12.3 & 12.6 & 8.9 & 12.3 & 10.6 \\
\hline & Min & -9.9 & -11.0 & -10.3 & -8.7 & -10.9 & -10.9 & 1.7 & -2.9 & -3.0 & -12.1 & -9.4 & -13.8 \\
\hline & Percentile $90 \%$ & -0.9 & -1.6 & -0.1 & 0.8 & -1.7 & -0.4 & 10.3 & 11.0 & 7.2 & 7.9 & 9.6 & 6.0 \\
\hline & Percentile 10\% & -9.8 & -10.6 & -9.4 & -5.7 & -10.4 & -10.4 & 3.8 & 1.7 & 1.8 & -4.9 & -6.9 & -9.8 \\
\hline \multirow{6}{*}{ 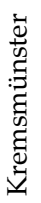 } & Mean & -7.0 & -7.4 & -7.3 & -5.5 & -7.3 & -7.3 & 6.9 & 6.4 & 6.0 & 1.7 & 2.0 & 0.8 \\
\hline & Median & -7.0 & -8.5 & -8.8 & -6.4 & -8.5 & -8.8 & 8.0 & 5.9 & 6.1 & 3.0 & 1.8 & 0.1 \\
\hline & Max & 0.0 & 2.3 & 2.9 & 0.4 & 2.3 & 2.9 & 9.7 & 9.9 & 8.9 & 8.8 & 7.8 & 8.2 \\
\hline & Min & -10.8 & -11.1 & -12.3 & -10.0 & -11.2 & -12.2 & 0.1 & 2.0 & 3.4 & -6.8 & -6.2 & -5.2 \\
\hline & Percentile 90\% & -3.3 & -3.1 & -1.8 & -0.8 & -3.1 & -1.8 & 9.5 & 8.9 & 8.6 & 4.8 & 7.4 & 6.4 \\
\hline & Percentile $10 \%$ & -10.3 & -10.9 & -10.9 & -9.4 & -10.7 & -10.9 & 3.6 & 3.9 & 3.4 & -3.0 & -5.3 & -4.8 \\
\hline
\end{tabular}

\section{Appendix E}

Table A5. Mean, Median, Maximum (Max), and Minimum (Min) values for yield differences (\%) across 5, 11, and $21 \mathrm{~km}$ aggregated data in maize (rainfed = no irr, optimally irrigated = irr), winter wheat, and spring barley (rainfed) grown on three different soils; $1 \mathrm{~km}$ input data vs. aggregated data of three ÖKS15 projections in RCP 4.5 (EC-Earth_RCA, IPSL_RCA and HadGEM_CLM) in Poysdorf, Bad Gleichenberg and Kremsmünster for the (a) baseline and (b) 2071-2100 period.

\begin{tabular}{|c|c|c|c|c|c|c|c|c|c|c|c|c|}
\hline \multicolumn{13}{|c|}{ (a) RCP 4.5 1981-2010-Poysdorf. } \\
\hline Soil & 1 & 2 & 3 & 1 & 2 & 3 & 1 & 2 & 3 & 1 & 2 & 3 \\
\hline $\begin{array}{c}\text { Yield } \\
\text { Difference \% }\end{array}$ & & Mean & & & Median & & & Max & & & Min & \\
\hline \multicolumn{13}{|c|}{ RCP 4.5, EC-EARTH_RCA } \\
\hline maize_no irr & 0.7 & 1.0 & -0.1 & 0.9 & 1.1 & 0.0 & 1.1 & 1.5 & 0.1 & 0.2 & 0.5 & -0.6 \\
\hline maize_irr & 9.0 & 9.3 & 2.9 & 10.4 & 10.2 & 2.9 & 10.9 & 10.3 & 3.2 & 5.8 & 7.5 & 2.7 \\
\hline spring barley & -0.4 & -0.6 & 0.1 & -0.3 & -0.3 & 0.2 & 0.1 & -0.1 & 0.5 & -1.0 & -1.5 & -0.4 \\
\hline winter wheat & -0.4 & -0.2 & 0.8 & -0.3 & -0.4 & 0.2 & 0.3 & 0.4 & 2.4 & -1.2 & -0.6 & -0.1 \\
\hline
\end{tabular}


Table A5. Cont.

\begin{tabular}{|c|c|c|c|c|c|c|c|c|c|c|c|c|}
\hline \multicolumn{13}{|c|}{ (a) RCP 4.5 1981-2010-Poysdorf. } \\
\hline Soil & 1 & 2 & 3 & 1 & 2 & 3 & 1 & 2 & 3 & 1 & 2 & 3 \\
\hline $\begin{array}{c}\text { Yield } \\
\text { Difference \% }\end{array}$ & \multicolumn{3}{|c|}{ Mean } & \multicolumn{3}{|c|}{ Median } & \multicolumn{3}{|c|}{ Max } & \multicolumn{3}{|c|}{ Min } \\
\hline \multicolumn{13}{|c|}{ RCP 4.5, IPSL_RCA } \\
\hline maize_no irr & -1.6 & -0.8 & -1.4 & -1.6 & -0.8 & -1.4 & -1.5 & -0.6 & -1.2 & -1.7 & -1.1 & -1.6 \\
\hline maize_irr & -2.2 & 2.8 & -1.5 & -1.8 & 2.9 & -1.5 & 0.2 & 2.9 & -1.4 & -4.9 & 2.7 & -1.6 \\
\hline spring barley & 0.9 & -5.4 & -7.1 & 1.5 & -5.2 & -7.3 & 2.0 & -4.7 & -6.3 & -0.8 & -6.4 & -7.7 \\
\hline winter wheat & -9.5 & -5.5 & -6.6 & -9.2 & -5.2 & -6.3 & -9.0 & -5.0 & -6.3 & -10.4 & -6.2 & -7.1 \\
\hline \multicolumn{13}{|c|}{ RCP 4.5, HadGEM_CLM } \\
\hline maize_no irr & 0.7 & 0.2 & 0.7 & 0.5 & 0.0 & 0.6 & 1.5 & 1.0 & 1.0 & 0.2 & -0.4 & 0.4 \\
\hline maize_irr & 1.9 & 2.4 & 2.0 & 1.6 & 4.0 & 3.6 & 4.6 & 4.2 & 3.9 & -0.6 & -0.9 & -1.4 \\
\hline spring barley & 1.6 & 1.1 & 0.1 & 1.7 & 1.3 & 0.7 & 2.0 & 1.4 & 0.9 & 1.2 & 0.6 & -1.2 \\
\hline winter wheat & -3.3 & -0.9 & -2.6 & -3.4 & -1.0 & -2.7 & -2.8 & -0.5 & -2.3 & -3.8 & -1.2 & -2.8 \\
\hline \multicolumn{13}{|c|}{ (b) RCP 4.5 2071-2100-Poysdorf } \\
\hline \multicolumn{13}{|c|}{ RCP 4.5, EC-EARTH_RCA } \\
\hline maize_no irr & -2.3 & -2.6 & -3.0 & -2.2 & -2.5 & -3.0 & -1.9 & -2.2 & -2.7 & -2.9 & -3.2 & -3.2 \\
\hline maize_irr & 1.0 & -1.0 & -2.7 & 1.2 & -0.9 & -2.5 & 1.5 & -0.5 & -2.5 & 0.3 & -1.6 & -3.0 \\
\hline spring barley & 5.6 & 4.0 & 2.6 & 5.7 & 3.9 & 2.4 & 5.8 & 4.3 & 3.0 & 5.3 & 3.8 & 2.3 \\
\hline winter wheat & 2.6 & 1.9 & 2.2 & 2.7 & 1.9 & 2.1 & 3.0 & 2.4 & 3.1 & 2.1 & 1.3 & 1.4 \\
\hline \multicolumn{13}{|c|}{ RCP 4.5, IPSL_RCA } \\
\hline maize_no irr & 1.9 & 1.8 & 2.0 & 2.0 & 2.2 & 1.9 & 3.1 & 2.6 & 2.8 & 0.5 & 0.7 & 1.3 \\
\hline maize_irr & 7.9 & -0.8 & 1.3 & 9.0 & -0.2 & 1.7 & 9.0 & 0.2 & 2.2 & 5.6 & -2.5 & 0.1 \\
\hline spring barley & 0.9 & -2.3 & -2.9 & 0.8 & -2.3 & -2.8 & 1.0 & -1.9 & -2.2 & 0.8 & -2.5 & -3.6 \\
\hline winter wheat & 1.2 & -2.2 & -0.6 & 1.3 & -2.3 & -0.5 & 1.4 & -2.0 & -0.4 & 1.0 & -2.4 & -0.9 \\
\hline \multicolumn{13}{|c|}{ RCP 4.5, HadGEM_CLM } \\
\hline maize_no irr & 0.9 & 0.5 & 0.3 & 1.5 & 1.4 & 0.8 & 1.6 & 1.4 & 1.2 & -0.4 & -1.1 & -1.0 \\
\hline maize_irr & 3.7 & 0.0 & -0.5 & 3.9 & 0.6 & -0.6 & 5.2 & 0.6 & -0.4 & 2.1 & -1.3 & -0.6 \\
\hline spring barley & 0.2 & 0.6 & 0.8 & -0.1 & 0.7 & 0.8 & 0.9 & 1.0 & 1.0 & -0.3 & 0.2 & 0.7 \\
\hline winter wheat & 1.0 & -0.9 & -0.8 & 1.0 & -0.8 & -0.9 & 1.2 & -0.7 & -0.5 & 0.8 & -1.3 & -1.2 \\
\hline \multicolumn{13}{|c|}{ (a) RCP 4.5 1981-2010—Bad Gleichenberg } \\
\hline Soil & 1 & 2 & 3 & 1 & 2 & 3 & 1 & 2 & 3 & 1 & 2 & 3 \\
\hline $\begin{array}{c}\text { Yield } \\
\text { Difference \% }\end{array}$ & & Mean & & & Median & & & Max & & & Min & \\
\hline \multicolumn{13}{|c|}{ RCP 4.5, EC-EARTH_RCA } \\
\hline maize_no irr & 5.8 & 6.2 & 6.5 & 6.0 & 6.7 & $7 . \overline{-}$ & 6.5 & 7.0 & 7.4 & 4.9 & 4.9 & 5.1 \\
\hline maize_irr & 8.6 & 7.5 & 6.5 & 8.7 & 7.9 & 6.9 & 9.8 & 8.3 & 7.3 & 7.3 & 6.2 & 5.2 \\
\hline spring barley & 1.7 & 3.5 & 4.6 & 1.7 & 3.6 & 4.5 & 1.8 & 3.7 & 4.6 & 1.6 & 3.3 & 4.5 \\
\hline winter wheat & 3.3 & 0.6 & -0.1 & 3.3 & 0.7 & -0.2 & 3.8 & 0.7 & 0.1 & 2.7 & 0.4 & -0.4 \\
\hline \multicolumn{13}{|c|}{ RCP 4.5, IPSL_RCA } \\
\hline maize_no irr & -1.3 & 0.5 & -0.3 & -0.8 & 1.0 & 0.1 & -0.6 & 1.4 & 0.2 & -2.4 & -0.9 & -1.3 \\
\hline maize_irr & 4.2 & -0.2 & 2.5 & 3.9 & 0.4 & 2.9 & 5.4 & 0.4 & 3.0 & 3.3 & -1.4 & 1.5 \\
\hline spring barley & 4.7 & -0.2 & 1.0 & 4.5 & -0.2 & 1.2 & 5.4 & 0.1 & 1.3 & 4.1 & -0.5 & 0.7 \\
\hline winter wheat & 2.1 & -1.5 & -2.1 & 1.8 & -1.7 & -2.2 & 2.5 & -0.9 & -1.6 & 1.8 & -1.9 & -2.4 \\
\hline \multicolumn{13}{|c|}{ RCP 4.5, HadGEM_CLM } \\
\hline maize_no irr & 0.9 & 1.1 & 0.8 & 1.1 & 1.3 & 1.0 & 1.2 & 1.4 & 1.3 & 0.4 & 0.6 & -0.1 \\
\hline maize_irr & 0.4 & 0.0 & 0.6 & -0.1 & 0.1 & 0.8 & 2.2 & 0.4 & 1.1 & -1.0 & -0.4 & 0.0 \\
\hline spring barley & 0.8 & -1.1 & -0.6 & 0.9 & -1.0 & -0.5 & 1.1 & -0.9 & -0.4 & 0.3 & -1.4 & -0.9 \\
\hline winter wheat & -0.8 & -0.9 & -0.4 & -0.9 & -1.1 & -0.6 & -0.3 & -0.3 & 0.0 & -1.0 & -1.2 & -0.6 \\
\hline \multicolumn{13}{|c|}{ (b) RCP 4.5 2071-2100-Bad Gleichenberg } \\
\hline & & & & СР 4.5, & EC-EAF & TH_R & & & & & & \\
\hline maize_no irr & 0.7 & 2.2 & 1.1 & 1.2 & 2.8 & 1.1 & 1.5 & 3.4 & 1.6 & -0.6 & 0.4 & 0.7 \\
\hline maize_irr & 1.0 & 2.2 & 0.8 & 1.4 & 2.8 & 0.8 & 1.9 & 3.4 & 1.3 & -0.3 & 0.4 & 0.3 \\
\hline spring barley & 1.7 & -2.1 & -1.3 & 1.7 & -2.1 & -1.2 & 2.0 & -1.8 & -1.2 & 1.4 & -2.3 & -1.4 \\
\hline winter wheat & 0.4 & -0.1 & -0.6 & 0.5 & -0.3 & -0.7 & 1.2 & 0.3 & -0.1 & -0.4 & -0.3 & -0.9 \\
\hline
\end{tabular}


Table A5. Cont.

\begin{tabular}{|c|c|c|c|c|c|c|c|c|c|c|c|c|}
\hline \multicolumn{13}{|c|}{ (b) RCP 4.5 2071-2100-Bad Gleichenberg } \\
\hline \multicolumn{13}{|c|}{ RCP 4.5, IPSL_RCA } \\
\hline maize_no irr & 8.6 & 8.6 & 9.5 & 8.9 & 8.7 & 9.6 & 9.1 & 9.1 & 9.8 & 7.7 & 7.9 & 9.1 \\
\hline maize_irr & 11.5 & 8.6 & 9.9 & 11.4 & 8.7 & 10.0 & 12.4 & 9.1 & 10.2 & 10.6 & 7.9 & 9.5 \\
\hline spring barley & -0.5 & -1.7 & 0.5 & -0.3 & -1.6 & 0.4 & -0.2 & -1.6 & 0.8 & -0.9 & -2.0 & 0.4 \\
\hline winter wheat & 3.4 & -0.2 & 0.1 & 3.4 & -0.2 & 0.1 & 3.6 & -0.1 & 0.2 & 3.4 & -0.3 & 0.1 \\
\hline \multicolumn{13}{|c|}{ RCP 4.5, HadGEM_CLM } \\
\hline maize_no irr & 4.8 & 5.1 & 4.7 & 4.9 & 5.1 & 4.8 & 6.4 & 6.9 & 6.7 & 3.2 & 3.4 & 2.7 \\
\hline maize_irr & 1.7 & 5.4 & 4.2 & 1.5 & 5.2 & 4.0 & 3.4 & 7.1 & 6.0 & 0.3 & 3.7 & 2.7 \\
\hline spring barley & 0.0 & -0.3 & -0.6 & 0.0 & -0.4 & -0.8 & 0.0 & 0.0 & -0.2 & -0.1 & -0.6 & -0.9 \\
\hline winter wheat & 0.5 & -2.2 & -1.6 & 0.3 & -2.3 & -1.7 & 0.9 & -1.7 & -1.1 & 0.2 & -2.7 & -1.9 \\
\hline \multicolumn{13}{|c|}{ (a) RCP 4.5 1981-2010-Kremsmünster } \\
\hline Soil & 1 & 2 & 3 & 1 & 2 & 3 & 1 & 2 & 3 & 1 & 2 & 3 \\
\hline $\begin{array}{c}\text { Yield } \\
\text { Difference \% }\end{array}$ & & Mean & & & Median & & & Max & & & Min & \\
\hline \multicolumn{13}{|c|}{ RCP 4.5, EC-EARTH_RCA } \\
\hline maize_no irr & -0.8 & -0.5 & -0.8 & -0.9 & -0.5 & -0.8 & -0.3 & -0.2 & -0.5 & -1.2 & -0.6 & -0.9 \\
\hline maize_irr & 4.7 & -0.4 & -0.8 & 4.6 & -0.4 & -0.8 & 5.0 & -0.1 & -0.5 & 4.4 & -0.5 & -0.9 \\
\hline spring barley & -1.4 & -1.6 & -1.7 & -1.2 & -1.7 & -1.9 & -1.1 & -1.0 & -1.2 & -2.0 & -2.0 & -2.0 \\
\hline winter wheat & 0.5 & -2.7 & -2.3 & 0.4 & -2.9 & -2.5 & 0.7 & -2.0 & -1.7 & 0.3 & -3.0 & -2.6 \\
\hline \multicolumn{13}{|c|}{ RCP 4.5, IPSL_RCA } \\
\hline maize_no irr & -2.3 & 2.0 & 1.4 & -2.5 & 2.0 & 1.5 & -1.9 & 2.0 & 1.5 & -2.7 & 1.9 & 1.2 \\
\hline maize_irr & -2.5 & 0.9 & 1.4 & -2.5 & 0.9 & 1.5 & -2.3 & 1.1 & 1.5 & -2.6 & 0.7 & 1.1 \\
\hline spring barley & -2.2 & -1.4 & -1.5 & -2.1 & -1.4 & -1.3 & -1.9 & -0.9 & -1.0 & -2.6 & -1.9 & -2.1 \\
\hline winter wheat & -1.1 & -2.5 & -1.8 & -1.2 & -2.8 & -2.0 & -1.0 & -1.9 & -1.3 & -1.2 & -2.9 & -2.1 \\
\hline \multicolumn{13}{|c|}{ RCP 4.5, HadGEM_CLM } \\
\hline maize_no irr & 0.1 & 1.7 & 0.5 & 0.2 & 1.7 & 0.7 & 0.5 & 1.8 & 0.7 & -0.3 & 1.5 & 0.0 \\
\hline maize_irr & 2.2 & 1.5 & 0.6 & 2.2 & 1.6 & 0.8 & 2.3 & 1.6 & 0.9 & 1.9 & 1.4 & 0.2 \\
\hline spring barley & -0.3 & 1.1 & 0.8 & -0.3 & 1.2 & 0.9 & 0.2 & 1.4 & 1.0 & -0.7 & 0.8 & 0.5 \\
\hline winter wheat & -1.3 & -2.0 & -1.9 & -1.3 & -2.2 & -2.1 & -1.0 & -1.4 & -1.4 & -1.5 & -2.3 & -2.3 \\
\hline \multicolumn{13}{|c|}{ (b) RCP 4.5 2071-2100-Kremsmünser } \\
\hline \multicolumn{13}{|c|}{ RCP 4.5, EC-EARTH_RCA } \\
\hline maize_no irr & 1.3 & 2.4 & 4.1 & 1.2 & 2.4 & 4.1 & 1.5 & 2.7 & 4.2 & 1.0 & 2.2 & 3.8 \\
\hline maize_irr & 3.7 & 2.5 & 4.1 & 3.7 & 2.4 & 4.1 & 3.9 & 2.7 & 4.2 & 3.5 & 2.2 & 3.8 \\
\hline spring barley & -2.0 & -2.7 & -3.4 & -1.8 & -2.7 & -3.5 & -1.7 & -2.4 & -3.2 & -2.6 & -2.9 & -3.7 \\
\hline winter wheat & 0.8 & -10.0 & -8.4 & 0.7 & -10.2 & -8.6 & 0.9 & -9.6 & -8.0 & 0.7 & -10.2 & -8.6 \\
\hline \multicolumn{13}{|c|}{ RCP 4.5, IPSL_RCA } \\
\hline maize_no irr & 1.0 & 3.3 & 1.2 & 0.9 & 3.4 & 1.2 & 1.6 & 3.7 & 1.4 & 0.6 & 2.9 & 0.9 \\
\hline maize_irr & 1.3 & 3.4 & 1.2 & 1.3 & 3.4 & 1.2 & 1.7 & 3.7 & 1.5 & 0.9 & 3.0 & 0.9 \\
\hline spring barley & 2.1 & 0.5 & 0.1 & 2.0 & 0.4 & 0.0 & 2.3 & 0.9 & 0.5 & 1.9 & 0.3 & -0.1 \\
\hline winter wheat & -1.2 & -4.5 & -5.0 & -1.3 & -4.8 & -5.3 & -0.9 & -3.9 & -4.3 & -1.4 & -4.8 & -5.4 \\
\hline \multicolumn{13}{|c|}{ RCP 4.5, HadGEM_CLM } \\
\hline maize_no irr & 3.1 & 3.0 & 0.2 & 3.2 & 2.8 & -0.1 & 3.3 & 3.5 & 1.2 & 3.0 & 2.7 & -0.6 \\
\hline maize_irr & 3.4 & 2.9 & 0.2 & 3.4 & 2.7 & -0.1 & 3.6 & 3.4 & 1.2 & 3.4 & 2.6 & -0.6 \\
\hline spring barley & -1.0 & -0.9 & 0.2 & -1.0 & -1.1 & 0.0 & -0.4 & -0.2 & 0.9 & -1.5 & -1.4 & -0.4 \\
\hline winter wheat & -0.4 & -2.6 & -2.4 & -0.4 & -2.9 & -2.6 & 0.0 & -1.8 & -1.6 & -0.9 & -3.2 & -2.9 \\
\hline
\end{tabular}


Table A6. Mean, Median, Maximum (Max), and Minimum (Min) values for yield differences (\%) across 5, 11, and $21 \mathrm{~km}$ aggregated data in maize (rainfed = no irr, optimally irrigated = irr), winter wheat, and spring barley (rainfed) grown on three different soils; $1 \mathrm{~km}$ input data vs. aggregated data of five ÖKS15 projections in RCP 8.5 (EC-Earth_CLM, EC-Earth_RACMO, IPSL_WRF, IPSL_RCA and HadGEM_RCA) in Poysdorf, Bad Gleichenberg and Kremsmünster for the (a) baseline and (b) 2071-2100 period.

\begin{tabular}{|c|c|c|c|c|c|c|c|c|c|c|c|c|}
\hline \multicolumn{13}{|c|}{ (a) RCP 8.5 1981-2010-Poysdorf } \\
\hline soil & 1 & 2 & 3 & 1 & 2 & 3 & 1 & 2 & 3 & 1 & 2 & 3 \\
\hline $\begin{array}{c}\text { Yield } \\
\text { Difference \% }\end{array}$ & \multicolumn{3}{|c|}{ Mean } & \multicolumn{3}{|c|}{ Median } & \multicolumn{3}{|c|}{ Max } & \multicolumn{3}{|c|}{ Min } \\
\hline \multicolumn{13}{|c|}{ RCP 8.5, EC-EARTH_CLM } \\
\hline maize_no irr & 4.1 & 2.3 & 1.4 & 4.8 & 3.4 & 2.1 & 5.6 & 3.5 & 2.4 & 1.7 & 0.0 & -0.3 \\
\hline maize_irr & 1.1 & 1.1 & 1.6 & 1.4 & 1.5 & 2.3 & 1.8 & 1.9 & 2.5 & 0.2 & 0.1 & 0.2 \\
\hline spring barley & 0.9 & 0.3 & 0.6 & 0.9 & 0.3 & 0.8 & 1.6 & 0.3 & 0.9 & 0.3 & 0.1 & 0.0 \\
\hline winter wheat & 1.5 & 0.9 & 0.5 & 1.7 & 1.0 & 0.8 & 2.0 & 1.2 & 0.8 & 0.8 & 0.4 & -0.1 \\
\hline \multicolumn{13}{|c|}{ RCP 8.5, EC-EARTH_RACMO } \\
\hline maize_no irr & 1.7 & 2.8 & 2.9 & 2.8 & 3.8 & 3.7 & 3.2 & 4.4 & 4.5 & -0.9 & 0.4 & 0.4 \\
\hline maize_irr & 1.5 & 1.6 & 1.9 & 2.4 & 2.5 & 3.0 & 2.5 & 2.6 & 3.2 & -0.3 & -0.3 & -0.3 \\
\hline spring barley & 1.0 & 0.9 & 1.0 & 1.1 & 1.0 & 1.1 & 1.6 & 1.2 & 1.6 & 0.4 & 0.5 & 0.4 \\
\hline winter wheat & 0.6 & -2.7 & -1.3 & 0.6 & -2.6 & -1.4 & 0.7 & -2.6 & -1.0 & 0.5 & -2.9 & -1.5 \\
\hline \multicolumn{13}{|c|}{ RCP 8.5, IPSL_WRF } \\
\hline maize_no irr & 3.6 & 2.4 & 2.9 & 4.4 & 3.1 & 3.5 & 4.5 & 3.3 & 3.5 & 2.1 & 1.0 & 1.9 \\
\hline maize_irr & 0.2 & 0.1 & 0.4 & 0.1 & 0.0 & 0.4 & 0.5 & 0.5 & 0.8 & -0.1 & -0.1 & 0.0 \\
\hline spring barley & 1.2 & 1.2 & 1.5 & 1.6 & 1.4 & 2.0 & 1.7 & 1.7 & 2.0 & 0.4 & 0.6 & 0.5 \\
\hline winter wheat & 1.3 & 0.3 & 0.3 & 1.5 & 0.3 & 0.2 & 1.8 & 0.6 & 0.4 & 0.4 & 0.0 & 0.2 \\
\hline \multicolumn{13}{|c|}{ RCP 8.5, HadGEM_CLM } \\
\hline maize_no irr & 0.6 & -2.7 & -1.7 & 1.7 & -1.1 & 0.0 & 2.4 & -0.6 & 0.4 & -2.3 & -6.5 & -5.5 \\
\hline maize_irr & 0.3 & 0.2 & 0.4 & 0.0 & 0.1 & 0.1 & 1.4 & 1.4 & 1.2 & -0.4 & -0.8 & -0.1 \\
\hline spring barley & 2.8 & 1.1 & 0.2 & 3.1 & 1.0 & 0.9 & 3.6 & 1.9 & 1.0 & 1.8 & 0.3 & -1.3 \\
\hline winter wheat & 2.0 & 0.8 & 1.6 & 2.0 & 1.0 & 1.7 & 2.3 & 1.2 & 2.1 & 1.7 & 0.3 & 1.0 \\
\hline \multicolumn{13}{|c|}{ RCP 8.5, HadGEM_RCA } \\
\hline maize_no irr & 5.4 & 2.3 & -0.3 & 6.0 & 2.6 & -0.1 & 7.5 & 4.5 & 1.3 & 2.8 & -0.4 & -2.2 \\
\hline maize_irr & -0.1 & 0.1 & 0.3 & -0.3 & 0.3 & 0.4 & 1.0 & 0.7 & 1.0 & -0.9 & -0.6 & -0.5 \\
\hline spring barley & 0.8 & 1.4 & 1.5 & 0.8 & 1.4 & 1.9 & 1.1 & 1.7 & 2.1 & 0.6 & 1.1 & 0.5 \\
\hline winter wheat & 0.4 & 0.5 & 0.1 & 0.5 & 0.7 & 0.1 & 1.0 & 0.8 & 0.5 & -0.3 & 0.0 & -0.2 \\
\hline \multicolumn{13}{|c|}{ (b) RCP 8.5 2071-2100-Poysdorf } \\
\hline \multicolumn{13}{|c|}{ RCP 8.5, EC-EARTH_CLM } \\
\hline maize_no irr & 0.5 & -0.3 & 0.1 & 0.4 & -0.2 & 0.0 & 0.9 & -0.1 & 0.3 & 0.3 & -0.8 & 0.0 \\
\hline maize_irr & -0.1 & -0.4 & -1.0 & -0.2 & -0.2 & 0.0 & 0.2 & -0.1 & 0.3 & -0.4 & -0.8 & -3.3 \\
\hline spring barley & 1.1 & 0.5 & 0.5 & 1.1 & 0.4 & 0.6 & 1.5 & 0.7 & 0.6 & 0.6 & 0.3 & 0.4 \\
\hline winter wheat & 0.8 & 0.6 & 0.5 & 1.0 & 0.6 & 0.5 & 1.0 & 0.7 & 0.6 & 0.4 & 0.5 & 0.3 \\
\hline \multicolumn{13}{|c|}{ RCP 8.5, EC-EARTH_RACMO } \\
\hline maize_no irr & 0.6 & 0.2 & -0.1 & 0.5 & 0.0 & -0.8 & 0.7 & 0.5 & 1.3 & 0.5 & 0.0 & -0.8 \\
\hline maize_irr & -0.1 & 0.1 & -0.3 & -0.2 & 0.0 & -0.9 & 0.3 & 0.5 & 1.2 & -0.5 & -0.1 & -1.0 \\
\hline spring barley & 0.7 & 0.7 & 0.1 & 0.8 & 0.7 & 0.5 & 0.9 & 0.8 & 0.6 & 0.3 & 0.6 & -0.7 \\
\hline winter wheat & 0.8 & 1.9 & 0.4 & 0.8 & 1.9 & 0.4 & 1.1 & 1.9 & 0.5 & 0.5 & 1.9 & 0.3 \\
\hline \multicolumn{13}{|c|}{ RCP 8.5, IPSL_WRF } \\
\hline maize_no irr & 1.3 & 1.1 & 0.9 & 1.6 & 1.4 & 0.9 & 2.0 & 1.7 & 1.4 & 0.5 & 0.3 & 0.2 \\
\hline maize_irr & 0.9 & 1.1 & 0.9 & 1.1 & 1.4 & 0.9 & 1.4 & 1.7 & 1.4 & 0.2 & 0.3 & 0.2 \\
\hline spring barley & 0.0 & -0.2 & -0.6 & 0.0 & -0.2 & -0.3 & 0.1 & 0.2 & 0.0 & -0.1 & -0.7 & -1.3 \\
\hline winter wheat & 1.1 & 0.6 & 0.6 & 1.4 & 0.7 & 0.7 & 1.7 & 0.8 & 0.8 & 0.1 & 0.2 & 0.2 \\
\hline \multicolumn{13}{|c|}{ RCP 8.5, HadGEM_CLM } \\
\hline maize_no irr & 0.4 & 0.1 & -0.3 & 0.4 & 0.0 & -0.3 & 1.1 & 0.3 & -0.1 & -0.3 & -0.1 & -0.5 \\
\hline maize_irr & -0.1 & 0.7 & 0.0 & -0.3 & 1.0 & 0.2 & 0.3 & 1.0 & 0.3 & -0.3 & 0.1 & -0.4 \\
\hline spring barley & -0.4 & 2.9 & 1.9 & -0.5 & 2.8 & 1.9 & -0.2 & 3.4 & 2.1 & -0.6 & 2.5 & 1.7 \\
\hline winter wheat & 1.2 & 0.8 & 0.8 & 1.3 & 0.7 & 0.7 & 1.4 & 1.0 & 1.2 & 1.0 & 0.6 & 0.5 \\
\hline
\end{tabular}


Table A6. Cont.

(b) RCP 8.5 2071-2100—Poysdorf

\begin{tabular}{|c|c|c|c|c|c|c|c|c|c|c|c|c|}
\hline \multicolumn{13}{|c|}{ RCP 8.5, HadGEM_RCA } \\
\hline maize_no irr & -1.0 & -0.9 & -0.7 & -0.8 & -0.9 & -0.7 & -0.7 & -0.8 & -0.5 & -1.5 & -0.9 & -1.0 \\
\hline maize_irr & -0.7 & -0.9 & -1.4 & -0.5 & -0.8 & -1.3 & -0.5 & -0.8 & -1.1 & -1.0 & -1.0 & -1.7 \\
\hline spring barley & -1.0 & 0.8 & 2.3 & -0.6 & 0.4 & 2.1 & -0.4 & 1.6 & 2.8 & -1.9 & 0.3 & 2.1 \\
\hline winter wheat & 1.0 & 0.8 & 0.6 & 1.0 & 1.0 & 0.5 & 1.5 & 1.2 & 0.7 & 0.4 & 0.2 & 0.5 \\
\hline \multicolumn{13}{|c|}{ (a) RCP 8.5 1981-2010-Bad Gleichenberg } \\
\hline Soil & 1 & 2 & 3 & 1 & 2 & 3 & 1 & 2 & 3 & 1 & 2 & 3 \\
\hline $\begin{array}{c}\text { Yield } \\
\text { Difference \% }\end{array}$ & \multicolumn{3}{|c|}{ Mean } & \multicolumn{3}{|c|}{ Median } & \multicolumn{3}{|c|}{$\operatorname{Max}$} & \multicolumn{3}{|c|}{ Min } \\
\hline \multicolumn{13}{|c|}{ RCP 8.5, EC-EARTH_CLM } \\
\hline maize_no irr & 1.9 & 2.4 & 3.8 & 2.3 & 2.4 & 4.6 & 2.3 & 3.6 & 4.8 & 1.2 & 1.3 & 2.1 \\
\hline maize_irr & 1.5 & 2.3 & 3.8 & 1.4 & 2.3 & 4.5 & 2.4 & 3.5 & 4.8 & 0.6 & 1.2 & 2.0 \\
\hline spring barley & 0.2 & 0.1 & -0.3 & 0.2 & 0.0 & -0.3 & 0.7 & 0.5 & -0.1 & -0.3 & -0.3 & -0.6 \\
\hline winter wheat & 0.3 & -0.4 & -0.3 & 0.1 & -0.5 & -0.3 & 0.9 & -0.2 & -0.3 & -0.1 & -0.6 & -0.4 \\
\hline \multicolumn{13}{|c|}{ RCP 8.5, EC-EARTH_RACMO } \\
\hline maize_no irr & 1.6 & 1.7 & 1.3 & 1.5 & 1.7 & 1.3 & 2.1 & 2.3 & 1.6 & 1.2 & 1.3 & 1.1 \\
\hline maize_irr & 1.4 & 1.8 & 1.5 & 1.2 & 1.7 & 1.4 & 1.8 & 2.3 & 1.8 & 1.1 & 1.4 & 1.3 \\
\hline spring barley & 0.4 & -1.0 & -0.3 & 0.4 & -0.8 & -0.1 & 0.8 & -0.8 & 0.0 & -0.1 & -1.3 & -0.8 \\
\hline winter wheat & 0.0 & -1.0 & -0.7 & -0.1 & -1.1 & -0.8 & 0.2 & -0.8 & -0.3 & -0.1 & -1.2 & -0.8 \\
\hline \multicolumn{13}{|c|}{ RCP 8.5, IPSL_WRF } \\
\hline maize_no irr & 2.3 & 2.4 & 2.6 & 2.4 & 2.6 & 2.7 & 3.0 & 3.0 & 3.2 & 1.7 & 1.7 & 1.8 \\
\hline maize_irr & 2.3 & 2.4 & 2.6 & 2.4 & 2.6 & 2.7 & 3.0 & 3.0 & 3.2 & 1.7 & 1.7 & 1.8 \\
\hline spring barley & 0.3 & -1.2 & -0.8 & 0.0 & -1.3 & -0.8 & 1.2 & -1.1 & -0.6 & -0.2 & -1.4 & -0.9 \\
\hline winter wheat & 0.8 & -0.1 & 0.3 & 0.7 & 0.0 & 0.3 & 1.0 & 0.1 & 0.4 & 0.6 & -0.4 & 0.1 \\
\hline \multicolumn{13}{|c|}{ RCP 8.5, HadGEM_CLM } \\
\hline maize_no irr & -0.8 & 1.1 & 1.7 & -0.5 & 1.3 & 1.8 & 0.1 & 1.3 & 2.1 & -2.0 & 0.6 & 1.3 \\
\hline maize_irr & 2.1 & 2.2 & 1.7 & 2.2 & 2.3 & 2.0 & 2.6 & 2.6 & 2.0 & 1.6 & 1.6 & 1.0 \\
\hline spring barley & 0.2 & -0.6 & -0.6 & 0.5 & -0.6 & -0.6 & 0.6 & -0.4 & -0.3 & -0.5 & -0.9 & -0.9 \\
\hline winter wheat & 0.7 & 0.3 & 0.2 & 0.6 & 0.2 & 0.1 & 0.9 & 0.6 & 0.6 & 0.5 & 0.0 & 0.0 \\
\hline \multicolumn{13}{|c|}{ RCP 8.5, HadGEM_RCA } \\
\hline maize_no irr & 2.5 & 2.5 & 2.1 & 3.0 & 3.2 & 2.5 & 3.1 & 3.4 & 3.0 & 1.3 & 0.9 & 0.9 \\
\hline maize_irr & 2.4 & 2.5 & 2.2 & 2.7 & 3.1 & 2.2 & 3.2 & 3.5 & 3.1 & 1.2 & 1.0 & 1.1 \\
\hline spring barley & 0.6 & 0.0 & 0.5 & 0.7 & 0.2 & 0.6 & 1.0 & 0.7 & 1.1 & 0.3 & -0.8 & -0.3 \\
\hline winter wheat & 0.9 & -0.1 & 0.2 & 1.0 & 0.0 & 0.2 & 1.1 & 0.0 & 0.4 & 0.6 & -0.4 & 0.1 \\
\hline
\end{tabular}

(b) RCP 8.5 2071-2100-Bad Gleichenberg

\begin{tabular}{|c|c|c|c|c|c|c|c|c|c|c|c|c|}
\hline \multicolumn{13}{|c|}{ RCP 8.5, EC-EARTH_CLM } \\
\hline maize_no irr & 0.5 & 0.2 & 1.0 & 0.4 & 0.3 & 0.9 & 0.8 & 0.7 & 1.4 & 0.4 & -0.4 & 0.9 \\
\hline maize_irr & 0.6 & 0.2 & 0.2 & 0.6 & 0.3 & 0.1 & 1.1 & 0.7 & 0.5 & 0.2 & -0.4 & 0.0 \\
\hline spring barley & -1.0 & -1.2 & -1.0 & -1.1 & -1.3 & -1.0 & -0.5 & -1.1 & -0.6 & -1.3 & -1.3 & -1.2 \\
\hline winter wheat & 1.2 & -0.2 & 0.0 & 1.4 & 0.0 & 0.2 & 1.9 & 0.2 & 0.3 & 0.4 & -0.6 & -0.6 \\
\hline \multicolumn{13}{|c|}{ RCP 8.5, EC-EARTH_RACMO } \\
\hline maize_no irr & 1.8 & 2.5 & 3.7 & 1.8 & 2.0 & 2.9 & 1.8 & 3.4 & 5.9 & 1.7 & 2.0 & 2.4 \\
\hline maize_irr & 1.5 & 1.5 & 3.0 & 1.4 & 1.1 & 3.0 & 2.0 & 2.4 & 3.5 & 1.2 & 0.9 & 2.5 \\
\hline spring barley & 0.0 & -0.6 & -0.6 & 0.0 & -0.8 & -0.5 & 0.9 & 0.0 & -0.4 & -0.8 & -1.1 & -0.8 \\
\hline winter wheat & 0.4 & 0.0 & 0.6 & 0.5 & -0.1 & 0.5 & 0.8 & 0.3 & 1.0 & -0.1 & -0.1 & 0.3 \\
\hline \multicolumn{13}{|c|}{ RCP 8.5, IPSL_WRF } \\
\hline maize_no irr & -0.6 & -0.1 & 3.9 & -0.1 & -0.3 & 3.7 & 0.0 & 0.4 & 6.2 & -1.6 & -0.5 & 1.7 \\
\hline maize_irr & 0.6 & 0.2 & 0.2 & 0.6 & 0.3 & 0.1 & 1.1 & 0.7 & 0.5 & 0.2 & -0.4 & 0.0 \\
\hline spring barley & 0.2 & 0.1 & 0.0 & 0.0 & 0.1 & -0.1 & 0.7 & 0.5 & 0.5 & -0.2 & -0.2 & -0.5 \\
\hline winter wheat & 4.7 & 1.6 & 2.8 & 4.5 & 1.5 & 2.8 & 6.9 & 2.5 & 4.1 & 2.8 & 0.8 & 1.6 \\
\hline \multicolumn{13}{|c|}{ RCP 8.5, HadGEM_CLM } \\
\hline maize_no irr & -0.4 & 1.3 & 0.7 & -0.9 & 1.1 & 0.9 & 0.4 & 1.7 & 1.2 & -0.9 & 1.0 & -0.1 \\
\hline maize_irr & 1.0 & 1.2 & 0.7 & 0.8 & 1.0 & 0.9 & 1.7 & 1.6 & 1.2 & 0.6 & 0.9 & -0.1 \\
\hline spring barley & -0.9 & -1.7 & -1.1 & -1.1 & -1.8 & -1.1 & -0.6 & -1.5 & -1.1 & -1.2 & -1.9 & -1.2 \\
\hline winter wheat & 0.5 & -0.5 & -0.2 & 0.5 & -0.4 & -0.2 & 0.7 & -0.3 & 0.0 & 0.3 & -0.8 & -0.3 \\
\hline
\end{tabular}


Table A6. Cont.

(b) RCP 8.5 2071-2100-Bad Gleichenberg

\begin{tabular}{|c|c|c|c|c|c|c|c|c|c|c|c|c|}
\hline \multicolumn{13}{|c|}{ RCP 8.5, HadGEM_RCA } \\
\hline maize_no irr & 1.3 & 0.8 & 1.1 & 1.3 & 0.7 & 1.1 & 1.3 & 1.1 & 1.4 & 1.2 & 0.4 & 0.7 \\
\hline maize_irr & 1.3 & 0.8 & 0.3 & 1.3 & 0.7 & 0.4 & 1.3 & 1.1 & 0.6 & 1.2 & 0.4 & 0.0 \\
\hline spring barley & 1.1 & 2.4 & 0.7 & 1.1 & 2.3 & 0.6 & 1.7 & 3.4 & 1.1 & 0.5 & 1.5 & 0.4 \\
\hline winter wheat & 1.2 & 1.1 & 1.4 & 1.4 & 1.3 & 1.6 & 1.8 & 1.3 & 1.7 & 0.4 & 0.6 & 0.9 \\
\hline \multicolumn{13}{|c|}{ (a) RCP 8.5 1981-2010-Kremsmünster } \\
\hline Soil & 1 & 2 & 3 & 1 & 2 & 3 & 1 & 2 & 3 & 1 & 2 & 3 \\
\hline $\begin{array}{c}\text { Yield } \\
\text { Difference \% }\end{array}$ & \multicolumn{3}{|c|}{ Mean } & \multicolumn{3}{|c|}{ Median } & \multicolumn{3}{|c|}{ Max } & \multicolumn{3}{|c|}{ Min } \\
\hline \multicolumn{13}{|c|}{ RCP 8.5, EC-EARTH_CLM } \\
\hline maize_no irr & 0.3 & 1.4 & -0.1 & 0.3 & 1.4 & -0.9 & 0.8 & 1.5 & 1.5 & -0.1 & 1.2 & -0.9 \\
\hline maize_irr & -0.4 & 1.3 & 0.0 & -0.4 & 1.4 & -0.8 & 0.1 & 1.5 & 1.5 & -0.8 & 1.1 & -0.8 \\
\hline spring barley & 0.1 & -0.9 & -1.1 & 0.1 & -0.8 & -1.1 & 0.4 & -0.5 & -0.9 & -0.4 & -1.3 & -1.3 \\
\hline winter wheat & 1.0 & -1.0 & -0.7 & 1.0 & -1.1 & -0.8 & 1.0 & -0.5 & -0.1 & 0.9 & -1.4 & -1.0 \\
\hline \multicolumn{13}{|c|}{ RCP 8.5, EC-EARTH_RACMO } \\
\hline maize_no irr & -0.8 & 0.0 & -0.4 & -0.8 & -0.2 & -0.6 & -0.7 & 0.4 & 0.0 & -1.0 & -0.3 & -0.8 \\
\hline maize_irr & -1.3 & -0.1 & -0.5 & -1.3 & -0.2 & -0.6 & -1.0 & 0.4 & 0.0 & -1.7 & -0.4 & -0.8 \\
\hline spring barley & 0.4 & -1.4 & -1.7 & 0.4 & -1.3 & -1.6 & 0.5 & -1.3 & -1.6 & 0.3 & -1.5 & -2.0 \\
\hline winter wheat & -1.9 & -1.6 & -2.0 & -1.9 & -1.3 & -1.7 & -1.2 & -1.2 & -1.7 & -2.4 & -2.2 & -2.6 \\
\hline \multicolumn{13}{|c|}{ RCP 8.5, IPSL_WRF } \\
\hline maize_no irr & -0.3 & 1.3 & 1.3 & -0.5 & 1.3 & 1.3 & 0.1 & 1.5 & 1.5 & -0.6 & 1.2 & 1.1 \\
\hline maize_irr & -0.3 & 1.3 & 1.3 & -0.5 & 1.3 & 1.3 & 0.1 & 1.5 & 1.5 & -0.6 & 1.2 & 1.1 \\
\hline spring barley & -1.0 & -0.9 & -1.6 & -1.2 & -1.2 & -1.8 & -0.7 & -0.3 & -1.1 & -1.3 & -1.2 & -2.1 \\
\hline winter wheat & -0.7 & -2.1 & -1.9 & -0.8 & -2.4 & -2.1 & -0.4 & -1.4 & -1.3 & -1.0 & -2.4 & -2.2 \\
\hline \multicolumn{13}{|c|}{ RCP 8.5, HadGEM_CLM } \\
\hline maize_no irr & 2.6 & 2.0 & 0.9 & 2.6 & 2.0 & 0.9 & 2.9 & 2.4 & 1.1 & 2.2 & 1.7 & 0.7 \\
\hline maize_irr & 0.4 & 2.1 & 0.9 & 0.4 & 2.1 & 1.0 & 0.8 & 2.5 & 1.1 & -0.1 & 1.8 & 0.7 \\
\hline spring barley & 0.8 & 2.1 & 2.2 & 0.8 & 2.5 & 2.4 & 1.5 & 2.5 & 2.7 & 0.3 & 1.2 & 1.6 \\
\hline winter wheat & -0.2 & -1.2 & -1.1 & -0.5 & -1.6 & -1.6 & 0.5 & -0.1 & 0.0 & -0.6 & -2.0 & -1.8 \\
\hline \multicolumn{13}{|c|}{ RCP 8.5, HadGEM_RCA } \\
\hline maize_no irr & 0.7 & 0.6 & 3.3 & 0.7 & 0.7 & 3.6 & 0.9 & 0.9 & 4.1 & 0.7 & 0.3 & 2.2 \\
\hline maize_irr & 0.4 & 0.5 & 3.4 & 0.4 & 0.5 & 3.7 & 0.7 & 0.8 & 4.2 & 0.2 & 0.2 & 2.3 \\
\hline spring barley & 1.0 & 0.2 & 0.2 & 0.7 & -0.1 & -0.1 & 1.6 & 0.7 & 1.0 & 0.7 & -0.1 & -0.4 \\
\hline winter wheat & -0.8 & -1.7 & -1.6 & -0.8 & -1.9 & -1.8 & -0.5 & -1.0 & -1.0 & -0.9 & -2.2 & -1.9 \\
\hline
\end{tabular}

(b) RCP 8.5 2071-2100-Kremsmünster

\begin{tabular}{|c|c|c|c|c|c|c|c|c|c|c|c|c|}
\hline \multicolumn{13}{|c|}{ RCP 8.5, EC-EARTH_CLM } \\
\hline maize_no irr & -1.0 & -0.9 & 0.3 & -0.9 & -0.9 & 0.4 & -0.8 & -0.7 & 0.7 & -1.1 & -1.1 & -0.1 \\
\hline maize_irr & -1.1 & -0.9 & 0.3 & -1.1 & -0.9 & 0.4 & -1.0 & -0.7 & 0.7 & -1.3 & -1.1 & -0.1 \\
\hline spring barley & 0.2 & -0.5 & -0.3 & 0.0 & -0.8 & -0.5 & 0.5 & -0.1 & 0.2 & 0.0 & -0.8 & -0.7 \\
\hline winter wheat & 1.0 & -0.4 & -0.3 & 0.8 & -0.7 & -0.5 & 1.4 & 0.2 & 0.3 & 0.7 & -0.7 & -0.6 \\
\hline \multicolumn{13}{|c|}{ RCP 8.5, EC-EARTH_RACMO } \\
\hline maize_no irr & 0.3 & 1.7 & 0.8 & 0.5 & 1.7 & 0.8 & 0.5 & 2.3 & 0.9 & -0.3 & 1.2 & 0.6 \\
\hline maize_irr & 0.2 & 1.7 & 0.8 & 0.4 & 1.7 & 0.8 & 0.5 & 2.3 & 0.9 & -0.3 & 1.2 & 0.6 \\
\hline spring barley & 0.1 & -0.9 & -1.8 & 0.0 & -1.0 & -1.8 & 0.5 & -0.4 & -1.6 & -0.4 & -1.3 & -2.0 \\
\hline winter wheat & -1.3 & -2.4 & -2.1 & -1.6 & -2.8 & -2.7 & -0.4 & -1.3 & -0.8 & -1.9 & -3.0 & -2.8 \\
\hline \multicolumn{13}{|c|}{ RCP 8.5, IPSL_WRF } \\
\hline maize_no irr & -1.9 & 1.0 & 0.1 & -1.8 & 1.0 & 0.3 & -1.6 & 1.7 & 0.4 & -2.1 & 0.4 & -0.4 \\
\hline maize_irr & -1.4 & 1.0 & 0.1 & -1.6 & 1.0 & 0.3 & -0.4 & 1.7 & 0.4 & -2.1 & 0.4 & -0.4 \\
\hline spring barley & -0.2 & 0.0 & 0.7 & -0.2 & -0.2 & 0.8 & 0.1 & 0.4 & 0.8 & -0.7 & -0.2 & 0.4 \\
\hline winter wheat & 4.3 & 1.5 & 2.0 & 2.9 & 2.1 & 0.3 & 8.8 & 4.1 & 5.7 & 1.1 & -1.6 & 0.0 \\
\hline \multicolumn{13}{|c|}{ RCP 8.5, HadGEM_CLM } \\
\hline maize_no irr & 3.9 & 3.0 & 5.0 & 3.9 & 3.4 & 5.3 & 4.3 & 3.5 & 5.7 & 3.6 & 2.1 & 4.1 \\
\hline maize_irr & 3.5 & 3.0 & 2.0 & 3.4 & 3.4 & 1.0 & 3.9 & 3.5 & 4.1 & 3.2 & 2.1 & 0.7 \\
\hline spring barley & -0.6 & -0.2 & -1.4 & -0.8 & -0.3 & -1.6 & 0.0 & 0.4 & -0.9 & -0.9 & -0.7 & -1.7 \\
\hline winter wheat & -1.2 & -2.7 & -2.5 & -1.5 & -3.2 & -2.9 & -0.6 & -1.8 & -1.6 & -1.6 & -3.3 & -3.0 \\
\hline
\end{tabular}


Table A6. Cont.

\begin{tabular}{ccccccccccccc}
\hline \multicolumn{10}{c}{ (b) RCP 8.5 2071-2100_Kremsmünster } \\
\hline \multicolumn{10}{c}{ RCP 8.5, HadGEM_RCA } \\
\hline maize_no irr & 0.9 & 1.0 & 1.7 & 0.9 & 1.3 & 1.7 & 1.0 & 1.3 & 1.7 & 0.7 & 0.5 & 1.7 \\
maize_irr & 0.8 & 1.0 & 1.7 & 0.7 & 1.3 & 1.7 & 1.1 & 1.3 & 1.7 & 0.7 & 0.5 & 1.7 \\
spring barley & -2.4 & -3.0 & -2.8 & -2.3 & -3.3 & -3.0 & -2.1 & -2.3 & -2.2 & -2.6 & -3.4 & -3.2 \\
winter wheat & -1.7 & -2.8 & -2.7 & -2.0 & -3.1 & -3.1 & -1.0 & -1.7 & -1.7 & -2.2 & -3.6 & -3.4 \\
\hline
\end{tabular}

\section{References}

1. Eitzinger, J.; Thaler, S.; Schmid, E.; Strauss, F.; Ferrise, R.; Moriondo, M.; Bindi, M.; Palosuo, T.; Rötter, R.; Kersebaum, K.C.; et al. Sensitivities of crop models to extreme weather conditions during flowering period demonstrated for maize and winter wheat in Austria. J. Agric. Sci. 2012, 151, 813-835. [CrossRef]

2. Makinen, H.; Kaseva, J.; Trnka, M.; Balek, J.; Kersebaum, K.C.; Nendel, C.; Gobin, A.; Olesen, J.E.; Bindi, M.; Ferrise, R.; et al. Sensitivity of European wheat to extreme weather. Field Crop. Res. 2018, 222, 209-217. [CrossRef]

3. Rötter, R.P.; Appiah, M.; Fichtler, E.; Kersebaum, K.C.; Trnka, M.; Hoffmann, M.P. Linking modelling and experimentation to better capture crop impacts of agroclimatic extremes-A review. Field Crop. Res. 2018, 221, 142-156. [CrossRef]

4. Pullens, J.W.M.; Sharif, B.; Trnka, M.; Balek, J.; Semenov, M.A.; Olesen, J.E. Risk factors for European winter oilseed rape production under climate change. Agric. For. Meteorol. 2019, 272, 30-39. [CrossRef]

5. Uddameri, V.; Ghaseminejad, A.; Hernandez, E.A. A tiered stochastic framework for assessing crop yield loss risks due to water scarcity under different uncertainty levels. Agric. Water Manag. 2020, 238, 12. [CrossRef]

6. Martre, P.; Wallach, D.; Asseng, S.; Ewert, F.; Jones, J.W.; Rötter, R.P.; Boote, K.J.; Ruane, A.C.; Thorburn, P.J.; Cammarano, D.; et al. Multimodel ensembles of wheat growth: Many models are better than one. Glob Chang. Biol 2015, 21, 911-925. [CrossRef] [PubMed]

7. Chenu, K.; Porter, J.R.; Martre, P.; Basso, B.; Chapman, S.C.; Ewert, F.; Bindi, M.; Asseng, S. Contribution of Crop Models to Adaptation in Wheat. Trends Plant Sci. 2017, 22, 472-490. [CrossRef]

8. White, J.W.; Hoogenboom, G.; Kimball, B.A.; Wall, G.W. Methodologies for simulating impacts of climate change on crop production. Field Crop. Res. 2011, 124, 357-368. [CrossRef]

9. Laudien, R.; Schauberger, B.; Gleixner, S.; Gornott, C. Assessment of weather-yield relations of starchy maize at different scales in Peru to support the NDC implementation. Agric. For. Meteorol. 2020, 295, 12. [CrossRef]

10. Manivasagam, V.S.; Rozenstein, O. Practices for upscaling crop simulation models from field scale to large regions. Comput. Electron. Agric. 2020, 175, 10. [CrossRef]

11. Lobell, D.B.; Ortiz-Monasterio, J.I.; Falcon, W.P. Yield uncertainty at the field scale evaluated with multi-year satellite data. Agric. Syst. 2007, 92, 76-90. [CrossRef]

12. Challinor, A.J.; Ewert, F.; Arnold, S.; Simelton, E.; Fraser, E. Crops and climate change: Progress, trends, and challenges in simulating impacts and informing adaptation. J. Exp. Bot. 2009, 60, 2775-2789. [CrossRef]

13. Tao, F.; Yokozawa, M.; Zhang, Z. Modelling the impacts of weather and climate variability on crop productivity over a large area: A new process-based model development, optimization, and uncertainties analysis. Agric. For. Meteorol. 2009, 149, 831-850. [CrossRef]

14. Rötter, R.P.; Palosuo, T.; Pirttioja, N.K.; Dubrovsky, M.; Salo, T.; Fronzek, S.; Aikasalo, R.; Trnka, M.; Ristolainen, A.; Carter, T.R. What would happen to barley production in Finland if global warming exceeded $4{ }^{\circ} \mathrm{C}$ ? A model-based assessment. Eur. J. Agron. 2011, 35, 205-214. [CrossRef]

15. Asseng, S. Uncertainties of Climate Change Impacts in Agriculture. Procedia Environ. Sci. 2015, 29, 304. [CrossRef]

16. Asseng, S.; Ewert, F.; Rosenzweig, C.; Jones, J.W.; Hatfield, J.L.; Ruane, A.C.; Boote, K.J.; Thorburn, P.J.; Rötter, R.P.; Cammarano, D.; et al. Uncertainty in simulating wheat yields under climate change. Nat. Clim. Chang. 2013, 3, 827-832. [CrossRef]

17. Rötter, R.P. Robust uncertainty. Nat. Clim. Chang. 2014, 4, 251-252. [CrossRef]

18. Wallach, D.; Mearns, L.O.; Ruane, A.C.; Rötter, R.P.; Asseng, S. Lessons from climate modeling on the design and use of ensembles for crop modeling. Clim. Chang. 2016, 139, 551-564. [CrossRef] [PubMed]

19. Wallach, D.; Nissanka, S.P.; Karunaratne, A.S.; Weerakoon, W.M.W.; Thorburn, P.J.; Boote, K.J.; Jones, J.W. Accounting for both parameter and model structure uncertainty in crop model predictions of phenology: A case study on rice. Eur. J. Agron. 2017, 88, 53-62. [CrossRef]

20. Del Grosso, S.J.; Smith, W.; Kraus, D.; Massad, R.S.; Vogeler, I.; Fuchs, K. Approaches and concepts of modelling denitrification: Increased process understanding using observational data can reduce uncertainties. Curr. Opin. Environ. Sustain. 2020, 47, 37-45. [CrossRef]

21. Kawakita, S.; Takahashi, H.; Moriya, K. Prediction and parameter uncertainty for winter wheat phenology models depend on model and parameterization method differences. Agric. For. Meteorol. 2020, 290, 10. [CrossRef]

22. Challinor, A.J.; Smith, M.S.; Thornton, P. Use of agro-climate ensembles for quantifying uncertainty and informing adaptation. Agric. For. Meteorol. 2013, 170, 2-7. [CrossRef] 
23. Tao, F.; Rotter, R.P.; Palosuo, T.; Gregorio Hernandez Diaz-Ambrona, C.; Minguez, M.I.; Semenov, M.A.; Kersebaum, K.C.; Nendel, C.; Specka, X.; Hoffmann, H.; et al. Contribution of crop model structure, parameters and climate projections to uncertainty in climate change impact assessments. Glob. Chang. Biol. 2018, 24, 1291-1307. [CrossRef] [PubMed]

24. Ruiz-Ramos, M.; Mínguez, M.I. Evaluating uncertainty in climate change impacts on crop productivity in the Iberian Peninsula. Clim. Res. 2010, 44, 69-82. [CrossRef]

25. Semenov, M.; Stratonovitch, P. Use of multi-model ensembles from global climate models for assessment of climate change impacts. Clim. Res. 2010, 41, 1-14. [CrossRef]

26. Zhang, Y.; Zhao, Y.; Wang, C.; Chen, S. Using statistical model to simulate the impact of climate change on maize yield with climate and crop uncertainties. Theor. Appl. Climatol. 2016, 130, 1065-1071. [CrossRef]

27. Finger, D.; Heinrich, G.; Gobiet, A.; Bauder, A. Projections of future water resources and their uncertainty in a glacierized catchment in the Swiss Alps and the subsequent effects on hydropower production during the 21st century. Water Resour. Res. 2012, 48. [CrossRef]

28. Ravazzani, G.; Ghilardi, M.; Mendlik, T.; Gobiet, A.; Corbari, C.; Mancini, M. Investigation of climate change impact on water resources for an Alpine basin in northern Italy: Implications for evapotranspiration modeling complexity. PLoS ONE 2014, 9 , e109053. [CrossRef]

29. Smith, P.C.; Heinrich, G.; Suklitsch, M.; Gobiet, A.; Stoffel, M.; Fuhrer, J. Station-scale bias correction and uncertainty analysis for the estimation of irrigation water requirements in the Swiss Rhone catchment under climate change. Clim. Chang. 2014, 127, 521-534. [CrossRef]

30. Stoffel, M.; Mendlik, T.; Schneuwly-Bollschweiler, M.; Gobiet, A. Possible impacts of climate change on debris-flow activity in the Swiss Alps. Clim. Chang. 2013, 122, 141-155. [CrossRef]

31. Tapiador, F.J.; Navarro, A.; Moreno, R.; Sanchez, J.L.; Garcia-Ortega, E. Regional climate models: 30 years of dynamical downscaling. Atmos. Res. 2020, 235, 104785. [CrossRef]

32. Angulo, C.; Roetter, R.; Trnka, M.; Pirttioja, N.; Gaiser, T.; Hlavinka, P.; Ewert, F. Characteristic 'fingerprints' of crop model responses data at different spatial resolutions to weather input. Eur. J. Agron. 2013, 49, 104-114. [CrossRef]

33. Eitzinger, J.; Formayer, H.; Thaler, S.; Trnka, M.; Zdenek, Z.; Alexandrov, V. Aspects on results and uncertainties of climate change impact simulation studies for agricultural crop production in Europe. Die Bodenkult. J. Land Manag. Food Environ. 2008, 59, 131-147.

34. Qian, B.; Jing, Q.; Smith, W.; Grant, B.; Cannon, A.J.; Zhang, X. Quantifying the uncertainty introduced by internal climate variability in projections of Canadian crop production. Environ. Res. Lett. 2020, 15, 074032. [CrossRef]

35. Rötter, R.P.; Carter, T.R.; Olesen, J.E.; Porter, J.R. Crop-climate models need an overhaul. Nat. Clim. Chang. 2011, 1, 175-177. [CrossRef]

36. Zhao, G.; Siebert, S.; Enders, A.; Rezaei, E.E.; Yan, C.; Ewert, F. Demand for multi-scale weather data for regional crop modeling. Agric. For. Meteorol. 2015, 200, 156-171. [CrossRef]

37. Austrian Panel on Climate Change (APCC). Österreichischer Sachstandsbericht Klimawandel 2014 (AAR14); Verlag der Österreichischen Akademie der Wissenschaften: Vienna, Austria, 2014; p. 1096.

38. Schönhart, M.; Mitter, H.; Schmid, E.; Heinrich, G.; Gobiet, A. Integrated Analysis of Climate Change Impacts and Adaptation Measures in Austrian Agriculture. Ger. J. Agric. Econ. 2014, 63, 156-176. [CrossRef]

39. Rezaei, E.E.; Siebert, S.; Ewert, F. Intensity of heat stress in winter wheat-Phenology compensates for the adverse effect of global warming. Environ. Res. Lett. 2015, 10, 024012. [CrossRef]

40. Chimani, B.; Heinrich, G.; Hofstätter, M.; Kerschbaumer, M.; Kienberger, S.; Leuprecht, A.; Lexer, A.; Peßenteiner, S.; Poetsch, M.S.; Salzmann, M.; et al. ÖKS15-Klimaszenarien für Österreich; Daten, Methoden und Klimaanalyse; ZAMG: Vienna, Austria, 2016. Available online: https:/ / data.ccca.ac.at/dataset/endbericht-oks15-klimaszenarien-fur-osterreich-daten-methodenklimaanalyse-v01/resource/06edd0c9-6b1b-4198-9f4f-8d550309f35b (accessed on 20 October 2021).

41. Chimani, B.; Matulla, C.; Eitzinger, J.; Hiebl, J.; Hofstätter, M.; Kubu, G.; Maraun, D.; Mendlik, T.; Schellander-Gorgas, T.; Thaler, S. GUIDELINE zur Nutzung der OeKS15-Klimawandelsimulationen; ZAMG: Vienna, Austria, 2019. Available online: https: / / data.ccca.ac.at/dataset/guideline-zur-nutzung-der-oeks15-klimawandelsimulationen-v0 2/resource/37729819-bf1a-4066-8909-d615f9a92728 (accessed on 20 October 2021).

42. Haslmayr, H.P.; Baumgarten, A.; Schwarz, M.; Huber, S.; Prokop, G.; Sedy, K.; Krammer, C.; Murer, E.; Pock, H.; Rodlauer, C.; et al. BEAT-Bodenbedarf für die Ernährungssicherung in Österreich; BMNT: Vienna, Austria, 2018.

43. Thaler, S.; Brocca, L.; Ciabatta, L.; Eitzinger, J.; Hahn, S.; Wagner, W. Effects of Different Spatial Precipitation Input Data on Crop Model Outputs under a Central European Climate. Atmosphere 2018, 9, 290. [CrossRef]

44. Van Vuuren, D.P.; Edmonds, J.; Kainuma, M.; Riahi, K.; Thomson, A.; Hibbard, K.; Hurtt, G.C.; Kram, T.; Krey, V.; Lamarque, J.-F.; et al. The representative concentration pathways: An overview. Clim. Chang. 2011, 109, 5. [CrossRef]

45. Moss, R.H.; Edmonds, J.A.; Hibbard, K.A.; Manning, M.R.; Rose, S.K.; van Vuuren, D.P.; Carter, T.R.; Emori, S.; Kainuma, M.; Kram, T.; et al. The next generation of scenarios for climate change research and assessment. Nature 2010, 463, 747-756. [CrossRef] [PubMed]

46. Clarke, L.; Edmonds, J.; Jacoby, H.; Pitcher, H.; Reilly, J.; Richels, R. Scenarios of Greenhouse Gas Emissions and Atmospheric Concentrations; U.S. Climate Change Science Program: Washington, DC, USA, 2007. 
47. Riahi, K.; Grubler, A.; Nakicenovic, N. Scenarios of long-term socio-economic and environmental development under climate stabilization. Technol. Forecast. Soc. Chang. 2007, 74, 887-935. [CrossRef]

48. Wise, M.; Calvin, K.; Thomson, A.; Clarke, L.; Bond-Lamberty, B.; Sands, R.; Smith, S.J.; Janetos, A.; Edmonds, J. Implications of Limiting $\mathrm{CO}_{2}$ Concentrations for Land Use and Energy. Science 2009, 324, 1183-1186. [CrossRef] [PubMed]

49. Jacob, D.; Petersen, J.; Eggert, B.; Alias, A.; Christensen, O.B.; Bouwer, L.M.; Braun, A.; Colette, A.; Déqué, M.; Georgievski, G.; et al. EURO-CORDEX: New high-resolution climate change projections for European impact research. Reg. Environ. Chang. 2014, 14, 563-578. [CrossRef]

50. Switanek, M.B.; Troch, P.A.; Castro, C.L.; Leuprecht, A.; Chang, H.I.; Mukherjee, R.; Demaria, E.M.C. Scaled distribution mapping: A bias correction method that preserves raw climate model projected changes. Hydrol. Earth Syst. Sci. 2017, 21, 2649-2666. [CrossRef]

51. Jones, J.W.; Hoogenboom, G.; Porter, C.H.; Boote, K.J.; Batchelor, W.D.; Hunt, L.A.; Wilkens, P.W.; Singh, U.; Gijsman, A.J.; Ritchie, J.T. The DSSAT cropping system model. Eur. J. Agron. 2003, 18, 235-265. [CrossRef]

52. Hoogenboom, G.; Porter, C.; Boote, K.; Shelia, V.; Wilkens, P.; Singh, U.; White, J.; Asseng, S.; Lizaso, J.; Moreno, P.; et al. Advances in Crop Modeling for a Sustainable Agriculture. In The DSSAT Crop Modeling Ecosystem; Boote, K., Ed.; Burleigh Dodds Science Publishing: Cambridge, UK, 2019; pp. 173-216.

53. Hoogenboom, G.; Porter, C.H.; Shelia, V.; Boote, K.J.; Singh, U.; White, J.W.; Hunt, L.A.; Ogoshi, R.; Lizaso, J.I.; Koo, J.; et al. Decision Support System for Agrotechnology Transfer (DSSAT) Version 4.7.5. Available online: https:/ / DSSAT.net (accessed on 7 October 2021).

54. Thaler, S.; Eitzinger, J.; Trnka, M.; Dubrovsky, M. Impacts of climate change and alternative adaptation options on winter wheat yield and water productivity in a dry climate in Central Europe. J. Agric. Sci. 2012, 150, 537-555. [CrossRef]

55. Eitzinger, J.; Trnka, M.; Semeradova, D.; Thaler, S.; SvobodovÁ, E.; Hlavinka, P.; ŠIska, B.; Takac, J.; Malatinska, L.; Novakova, M.; et al. Regional climate change impacts on agricultural crop production in Central and Eastern Europe-Hotspots, regional differences and common trends. J. Agric. Sci. 2012, 151, 787-812. [CrossRef]

56. Thaler, S.; Eitzinger, J.; Trnka, M.; Možný, M.; Hahn, S.; Wagner, W.; Hlavinka, P. The performance of Metop Advanced SCATterometer soil moisture data as a complementary source for the estimation of crop-soil water balance in Central Europe. J. Agric. Sci. 2018, 156, 577-598. [CrossRef]

57. Eyring, V.; Bony, S.; Meehl, G.A.; Senior, C.A.; Stevens, B.; Stouffer, R.J.; Taylor, K.E. Overview of the Coupled Model Intercomparison Project Phase 6 (CMIP6) experimental design and organization. Geosci. Model Dev. 2016, 9, 1937-1958. [CrossRef]

58. Fuhrer, J. Agroecosystem responses to combinations of elevated $\mathrm{CO}_{2}$, ozone, and global climate change. Agric. Ecosyst. Environ 2003, 97, 1-20. [CrossRef]

59. Trnka, M.; Rotter, R.P.; Ruiz-Ramos, M.; Kersebaum, K.C.; Olesen, J.E.; Zalud, Z.; Semenov, M.A. Adverse weather conditions for European wheat production will become more frequent with climate change. Nat. Clim. Chang. 2014, 4, 637-643. [CrossRef]

60. Porter, J.R.; Xie, L.; Challinor, A.; Cochrane, K.; Howden, S.; Iqbal, M.M.; Lobell, D.B.; Travasso, M.I.; Aggarwal, P.K.; Hakala, K.; et al. Food Security and Food Production Systems; Cambridge University Press: Cambridge, UK, 2014; pp. 485-534.

61. Myers, S.S.; Zanobetti, A.; Kloog, I.; Huybers, P.; Leakey, A.D.; Bloom, A.J.; Carlisle, E.; Dietterich, L.H.; Fitzgerald, G.; Hasegawa, T.; et al. Increasing $\mathrm{CO}_{2}$ threatens human nutrition. Nature 2014, 510, 139-142. [CrossRef] [PubMed]

62. Challinor, A.J.; Watson, J.; Lobell, D.B.; Howden, S.M.; Smith, D.R.; Chhetri, N. A meta-analysis of crop yield under climate change and adaptation. Nat. Clim. Chang. 2014, 4, 287-291. [CrossRef]

63. IPCC. Climate Change and Land: An IPCC Special Report on Climate Change, Desertification, Land Degradation, Sustainable Land Management, Food Security, and Greenhouse Gas Fluxes in Terrestrial Ecosystems; Shukla, P.R., Skea, J., Calvo Buendia, E., Masson-Delmotte, V., Pörtner, H.-O., Roberts, D.C., Zhai, P., Slade, R., Connors, S., van Diemen, R., et al., Eds.; IPCC: Genève, Switzerland, 2019.

64. Wheeler, T.; von Braun, J. Climate Change Impacts on Global Food Security. Science 2013, 341, 508-513. [CrossRef]

65. Teixeira, E.I.; Fischer, G.; van Velthuizen, H.; Walter, C.; Ewert, F. Global hot-spots of heat stress on agricultural crops due to climate change. Agric. For. Meteorol. 2013, 170, 206-215. [CrossRef]

66. Siebert, S.; Ewert, F. Spatio-temporal patterns of phenological development in Germany in relation to temperature and day length Agric. For. Meteorol. 2012, 152, 44-57. [CrossRef]

67. Trnka, M.; Hlavinka, P.; Semenov, M.A. Adaptation options for wheat in Europe will be limited by increased adverse weather events under climate change. J. R. Soc. Interface 2015, 12, 20150721. [CrossRef]

68. Nendel, C.; Rötter, R.P.; Thorburn, P.; Boote, K.; Ewert, F. Editorial Introduction to the Special Issue “Modelling cropping systems under climate variability and change: Impacts, risk and adaptation". Agric. Syst. 2018, 159, 139-143. [CrossRef]

69. Challinor, A. Agriculture: Forecasting food. Nat. Clim. Chang. 2011, 1, 103-104. [CrossRef]

70. Jones, J.W.; Antle, J.M.; Basso, B.; Boote, K.J.; Conant, R.T.; Foster, I.; Godfray, H.C.J.; Herrero, M.; Howitt, R.E.; Janssen, S.; et al. Toward a new generation of agricultural system data, models, and knowledge products: State of agricultural systems science. Agric. Syst. 2017, 155, 269-288. [CrossRef]

71. Maraun, D.; Truhetz, H.; Schaffer, A. Regional Climate Model Biases, Their Dependence on Synoptic Circulation Biases and the Potential for Bias Adjustment: A Process-Oriented Evaluation of the Austrian Regional Climate Projections. J. Geophys. Res. Atmos. 2021, 126, e2020JD032824. [CrossRef] 
72. Paeßens, B.; Manderscheid, R.; Pacholski, A.; Varga, B.; Erbs, M.; Kage, H.; Sieling, K.; Weigel, H.-J. Effects of free-air CO 2 enrichment and drought on root growth of field grown maize and sorghum. J. Agron. Crop Sci. 2019, 205, 477-489. [CrossRef]

73. Dier, M.; Sickora, J.; Erbs, M.; Weigel, H.-J.; Zörb, C.; Manderscheid, R. Positive effects of free air $\mathrm{CO}_{2}$ enrichment on $\mathrm{N}$ remobilization and post-anthesis $\mathrm{N}$ uptake in winter wheat. Field Crop. Res. 2019, 234, 107-118. [CrossRef]

74. Manderscheid, R.; Dier, M.; Erbs, M.; Sickora, J.; Weigel, H.-J. Nitrogen supply-A determinant in water use efficiency of winter wheat grown under free air $\mathrm{CO}_{2}$ enrichment. Agric. Water Manag. 2018, 210, 70-77. [CrossRef]

75. Manderscheid, R.; Erbs, M.; Burkart, S.; Wittich, K.P.; Löpmeier, F.J.; Weigel, H.J. Effects of Free-Air Carbon Dioxide Enrichment on Sap Flow and Canopy Microclimate of Maize Grown under Different Water Supply. J. Agron. Crop Sci. 2016, 202, 255-268. [CrossRef]

76. Kimball, B.A. Crop responses to elevated $\mathrm{CO}_{2}$ and interactions with $\mathrm{H}_{2} \mathrm{O}, \mathrm{N}$, and temperature. Curr. Opin. Plant Biol. 2016, 31, 36-43. [CrossRef] [PubMed]

77. Kimball, B.A.; Kobayashi, K.; Bindi, M. Responses of Agricultural Crops to Free-Air $\mathrm{CO}_{2}$ Enrichment. In Advances in Agronomy; Sparks, D.L., Ed.; Academic Press: Cambridge, MA, USA, 2002; Volume 77, pp. 293-368.

78. Manderscheid, R.; Pacholski, A.; Frühauf, C.; Weigel, H.-J. Effects of free air carbon dioxide enrichment and nitrogen supply on growth and yield of winter barley cultivated in a crop rotation. Field Crop. Res. 2009, 110, 185-196. [CrossRef]

79. Peters, W.; van der Velde, I.R.; van Schaik, E.; Miller, J.B.; Ciais, P.; Duarte, H.F.; van der Laan-Luijkx, I.T.; van der Molen, M.K.; Scholze, M.; Schaefer, K.; et al. Increased water-use efficiency and reduced $\mathrm{CO}_{2}$ uptake by plants during droughts at a continental scale. Nat. Geosci. 2018, 11, 744-748. [CrossRef]

80. Boote, K.J.; Allen, J.L.; Prasad, P.V.V.; Jones, J. Testing effects of climate change in crop models. In Handbook of Climate Change and Agroecosystems; Imperial College Press: London, UK, 2010; Volume 1, pp. 109-129.

81. Ebrahimi, E.; Manschadi, A.M.; Neugschwandtner, R.W.; Eitzinger, J.; Thaler, S.; Kaul, H.P. Assessing the impact of climate change on crop management in winter wheat-A case study for Eastern Austria. J. Agric. Sci. 2016, 154, 1153-1170. [CrossRef]

82. Thaler, S.; Eitzinger, J.; Rischbeck, P.M.; Dubrovsky, M.; Trnka, M. Vulnerability of crops to climate change in Northeastern Austria. Bulg. J. Meteorol. Hydrol. 2010, 15, 50-61.

83. Strauss, F.; Schmid, E.; Moltchanova, E.; Formayer, H.; Wang, X.Y. Modeling climate change and biophysical impacts of crop production in the Austrian Marchfeld Region. Clim. Chang. 2012, 111, 641-664. [CrossRef] 